Supporting Information

\title{
Asymmetric Hydroboration of Ketones by Cooperative Lewis Acid/ Onium Salt Catalysis: A Quantum Chemical and Microkinetic Study to Combine Theory and Experiment
}

Juliane Heitkämper, ${ }^{\dagger}$ Justin Herrmann, ${ }^{\ddagger}$ Marvin Titze, ${ }^{\ddagger}$ Soeren Bauch, ${ }^{\dagger}$ René Peters, ${ }^{\ddagger}$ Johannes Kästner ${ }^{\dagger}$

† Institute for Theoretical Chemistry, University of Stuttgart, Pfaffenwaldring 55, 70569Stuttgart, Germany

$\ddagger$ Institute of Organic Chemistry, University of Stuttgart, Pfaffenwaldring 55, 70569Stuttgart, Germany

E-mail: kaestner@theochem.uni-stuttgart.de Phone: +49 (0)711 685-64473 


\section{Contents}

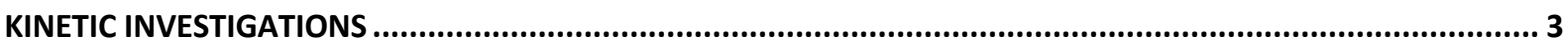

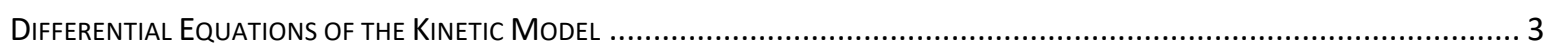

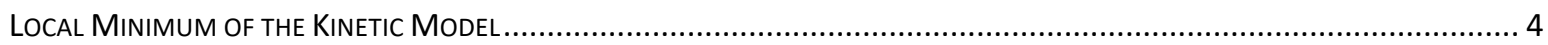

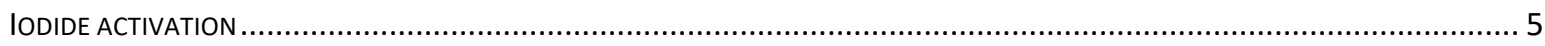

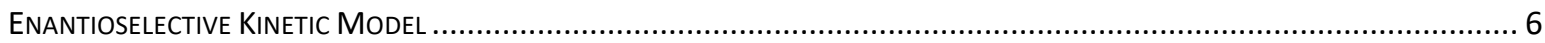

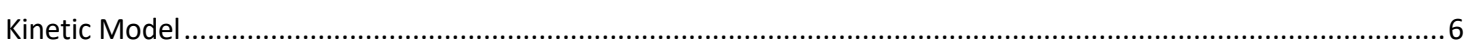

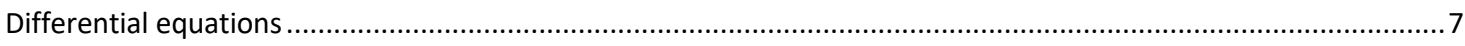

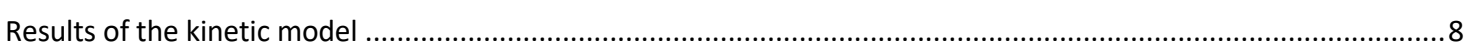

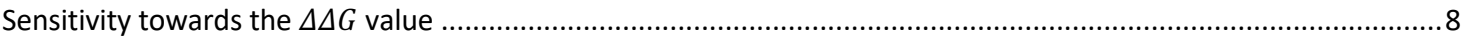

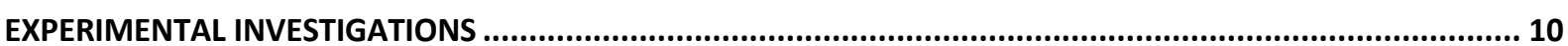

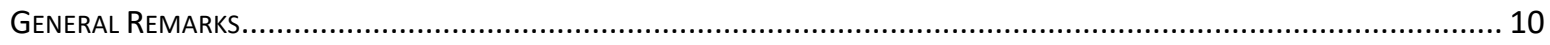

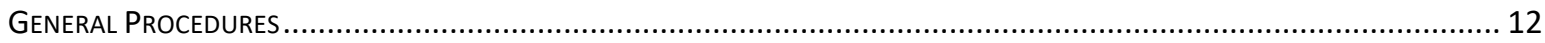

General Procedure for the In-Situ Formation of Al-Salen-Catalysts (GP1) ........................................... 12

General Procedure for the Continuous Reaction Monitoring of the Esterification of Pinacolborane with Secondary Alcohols in the Absence of Halide lons (GP2).

General Procedure for the Continuous Reaction Monitoring of the Esterification of Pinacolborane with

Secondary Alcohols using TBAX Salts as Halide Sources (GP3).

General Procedure for the Continuous Reaction Monitoring of the Esterification of Pinacolborane with

Secondary Alcohols using Lewis Acid/ Onium Salt Catalysts as Halide Sources (GP4) ............................... 13

LIGAND SYNTHESIS

1-(5-(tert-Butyl)-3-((E)-(((1S,2S)-2-(((E)-3,5-di-tert-butyl-2-

hydroxybenzylidene)amino)cyclohexyl)imino)methyl)-2-hydroxybenzyl)-N, N-diethyl-N-

methylmethanammonium Triflate (L1-OTf)

$N-(5-($ tert-Butyl)-3-((E)-(((1S,2S)-2-(((E)-3,5-di-tert-butyl-2-hydroxybenzylidene)amino)-

cyclohexyl)imino)methyl)-2-hydroxybenzyl)-N-diethyl-N-

methylmethanammonium Tetrakis[3,5-bis(trifluoromethyl)- phenyl]borate (L1-BAr $\left.{ }^{F}\right)$......................... 15

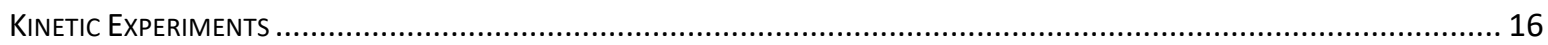

Continuous Reaction Monitoring of the Esterification of Pinacolborane with (R)-1-Phenylethanol by ${ }^{1} \mathrm{H}$ NMR spectroscopy.

Reaction Monitoring in the Absence of a Halide Source ................................................................ 16

Reaction Monitoring with the Addition of TBACl as Chloride Source ..............................................................18

Reaction Monitoring with the Addition of TBAl as lodide Source .........................................................................20

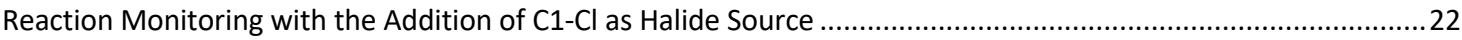

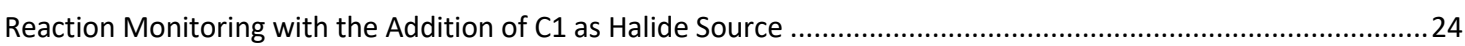

Continuous Reaction Monitoring of the Esterification of Pinacolborane with Isopropanol by ${ }^{1} \mathrm{H}-\mathrm{NMR}$

Spectroscopy 


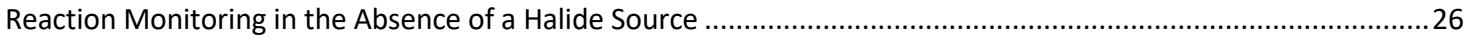

Reaction Monitoring with the Addition of TBACl as Chloride Source ....................................................................28

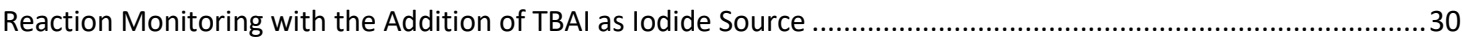

Reaction Monitoring with the Addition of $\mathrm{C} 1-\mathrm{Cl}$ as Halide Source .........................................................................32

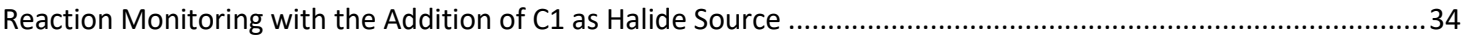

Continuous Reaction Monitoring of the Asymmetric Reduction of Acetophenone with Pinacolborane and C1-Cl by ${ }^{1} \mathrm{H}-\mathrm{NMR}$ Spectroscopy.

Continuous Reaction Monitoring of the Asymmetric Reduction of Acetophenone with Pinacolborane and C1-I by ${ }^{1} H-N M R$ Spectroscopy.....

Continuous Reaction Monitoring of the Asymmetric Reduction of Acetophenone with Pinacolborane and C1-12 by ${ }^{1} \mathrm{H}-\mathrm{NMR}$ Spectroscopy.

Continuous Reaction Monitoring of the Asymmetric Reduction of Acetophenone with Pinacolborane, C1 and 2 as Proton Source by ${ }^{1} \mathrm{H}-\mathrm{NMR}$ Spectroscopy

Continuous Reaction Monitoring of the Asymmetric Reduction of Acetophenone with Pinacolborane and C1 by ${ }^{1} \mathrm{H}-N M R$ Spectroscopy with Extended Reaction Time 50

Continuous Reaction Monitoring of the Esterification of Isopropanol with Pinacolborane and C1 by ${ }^{1} \mathrm{H}-\mathrm{NMR}$ under Standard Conditions.

1-(5-(tert-Butyl)-3-((E)-(((1S,2S)-2-(((E)-3,5-di-tert-butyl-2-

hydroxybenzylidene)amino)cyclohexyl)imino)methyl)-2-hydroxybenzyl)- $N, N$-diethyl- $N$ -

methylmethanammonium Triflate (L1-OTf)

$N-(5-(t e r t-B u t y l)-3-((E)-(((1 S, 2 S)-2-(((E)-3,5-d i-t e r t-b u t y l-2-h y d r o x y b e n z y l i d e n e) a m i n o)-$

cyclohexyl)imino)methyl)-2-hydroxybenzyl)-N-diethyl- $N$ -

methylmethanammonium Tetrakis[3,5-bis(trifluoromethyl)- phenyl]borate (L1-BAF $F^{F}$

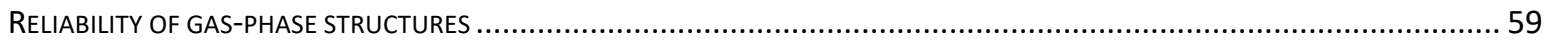

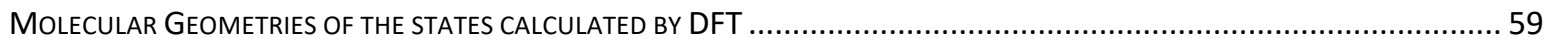

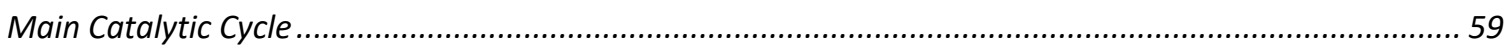

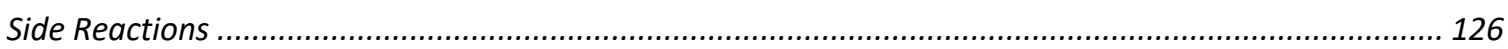

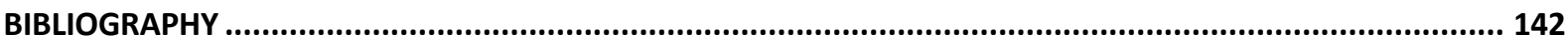




\section{Kinetic Investigations}

\section{Differential Equations of the Kinetic Model}

The set of ordinary differential equations (ODEs) that are derived from the kinetic model proposed in Table 1 in the manuscript is:

$$
\begin{aligned}
\frac{d[1]}{d t} & =-k_{\mathrm{R} 1}[\mathrm{Cat}][1]-k_{\mathrm{R} 5}[\mathrm{C}][1]+k_{\mathrm{R} 6}[\mathrm{~A}][2] \\
\frac{d[\mathrm{~A}]}{d t} & =k_{\mathrm{R} 1}[\mathrm{Cat}][1]-k_{\mathrm{R} 2}[\mathrm{~A}][\mathrm{HBPin}]+k_{\mathrm{R} 5}[\mathrm{C}][1]-k_{\mathrm{R} 6}[\mathrm{~A}][2] \\
\frac{d[\mathrm{HBPin}]}{d t} & =-k_{\mathrm{R} 2}[\mathrm{~A}][\mathrm{HBPin}]-k_{\mathrm{R} 7}[\mathrm{iPrOH}]\left[\mathrm{Cl}^{-}\right]-k_{\mathrm{R} 8}[11][2] \\
\frac{d[\mathrm{~B}]}{d t} & =k_{\mathrm{R} 2}[\mathrm{~A}][\mathrm{HBPin}]-k_{\mathrm{R} 3}[\mathrm{~B}][\mathrm{iPrOH}]-k_{\mathrm{R} 4}[\mathrm{~B}][2] \\
\frac{d[\mathrm{iPrOH}]}{d t} & =-k_{\mathrm{R} 3}[\mathrm{~B}][\mathrm{PrOH}]-k_{\mathrm{R} 7}[\mathrm{iPrOH}]\left[\mathrm{Cl}^{-}\right] \\
\frac{d[\mathrm{C}]}{d t} & =k_{\mathrm{R} 3}[\mathrm{~B}][\mathrm{iPrOH}]+k_{\mathrm{R} 4}[\mathrm{~B}][2]-k_{\mathrm{R} 5}[\mathrm{C}][1]+k_{\mathrm{R} 6}[\mathrm{~A}][2] \\
\frac{d[\mathrm{PrOBPin}]}{d t} & =k_{\mathrm{R} 3}[\mathrm{~B}][\mathrm{iPrOH}]+k_{\mathrm{R} 7}[\mathrm{iPrOH}]\left[\mathrm{Cl}-{ }^{-}\right] \\
\frac{d[2]}{d t} & =-k_{\mathrm{R} 4}[\mathrm{~B}][2]+k_{\mathrm{R} 5}[\mathrm{C}][1]-k_{\mathrm{R} 6}[\mathrm{~A}][2]-k_{\mathrm{R} 8}\left[\mathrm{Cl} l^{-}\right][2] \\
\frac{d[2 \mathrm{BPin}]}{d t} & =k_{\mathrm{R} 4}[\mathrm{~B}][2]+k_{\mathrm{R} 8}\left[\mathrm{Cl}{ }^{-}\right][2] \\
\frac{d[\mathrm{Cat}]}{d t} & =-k_{\mathrm{R} 1}[\mathrm{Cat}][1] \\
\frac{d[\mathrm{Cl}]}{d t} & =k_{\mathrm{R} 1}[\mathrm{Cat}][1]
\end{aligned}
$$

The side reactions $\mathbf{R 7}$ and $\mathbf{R 8}$ are catalyzed by $\mathrm{Cl}^{-}$ions. We include this in our model by assuming a pre-reactive complex $\mathrm{Cl}$-HBPin to form fast and efficiently, i.e. at any point in time with the concentration of $\mathrm{Cl}^{-}$, since this is always much lower than the concentration of HBPin, which is added in excess. This is why $\left[\mathrm{Cl}^{-}\right]$enters five of the above equations.

Furthermore the concentration of the THF solvent was assumed to be constant. The barrier for $\mathbf{R} 1$ is starting from a structure where THF and the catalyst are in close proximity already as it can be assumed that the catalyst is surrounded by solvent molecules. 


\section{Local Minimum of the Kinetic Model}

Starting the minimization of SE with respect to the reaction barriers from calculated DFT values, the optimization converges to a local minimum of $\mathrm{SE}=0.96 \mathrm{~mol}^{2} \mathrm{l}^{-2}$. The resulting free energy barriers $\Delta \mathrm{G}_{\mathrm{KM}, 2}$ are listed in Table $\mathrm{S} 1$ and the concentration-time-profile is shown in Figure S1. Manual adjustment of the barriers of the side reactions results in a minimum with a smaller $\mathrm{SE}=0.73 \mathrm{~mol}^{2} \mathrm{l}^{-2}$.

Table S1: Reaction barriers obtained from DFT calculations $\left(\Delta \mathrm{G}_{\mathrm{DFT}}\right)$ compared to those from the kinetic modeling $\left(\Delta \mathrm{G}_{\mathrm{KM}, 2}\right)$ for the local minimum with $\mathrm{SE}=0.96 \mathrm{~mol}^{2} \mathrm{l}^{-2}$.

\begin{tabular}{|c|c|c|}
\hline \multirow[t]{2}{*}{ Reaction } & $\Delta G_{\mathrm{DFT}}$ & $\Delta G_{\mathrm{KM}, 2}$ \\
\hline & \multicolumn{2}{|c|}{$\mathrm{kJ} \mathrm{mol}^{-1}$} \\
\hline R1 & 91.3 & 91.2 \\
\hline $\mathrm{R} 2$ & 81.7 & 77.4 \\
\hline R3 & 36.4 & 35.0 \\
\hline R4 & 32.8 & 34.2 \\
\hline R5 & 79.4 & 75.2 \\
\hline R6 & 63.4 & 67.5 \\
\hline R7 & 98.8 & 98.7 \\
\hline R8 & 95.8 & 95.7 \\
\hline$S E\left[\mathrm{~mol}^{2} I^{-2}\right]$ & & 0.96 \\
\hline
\end{tabular}

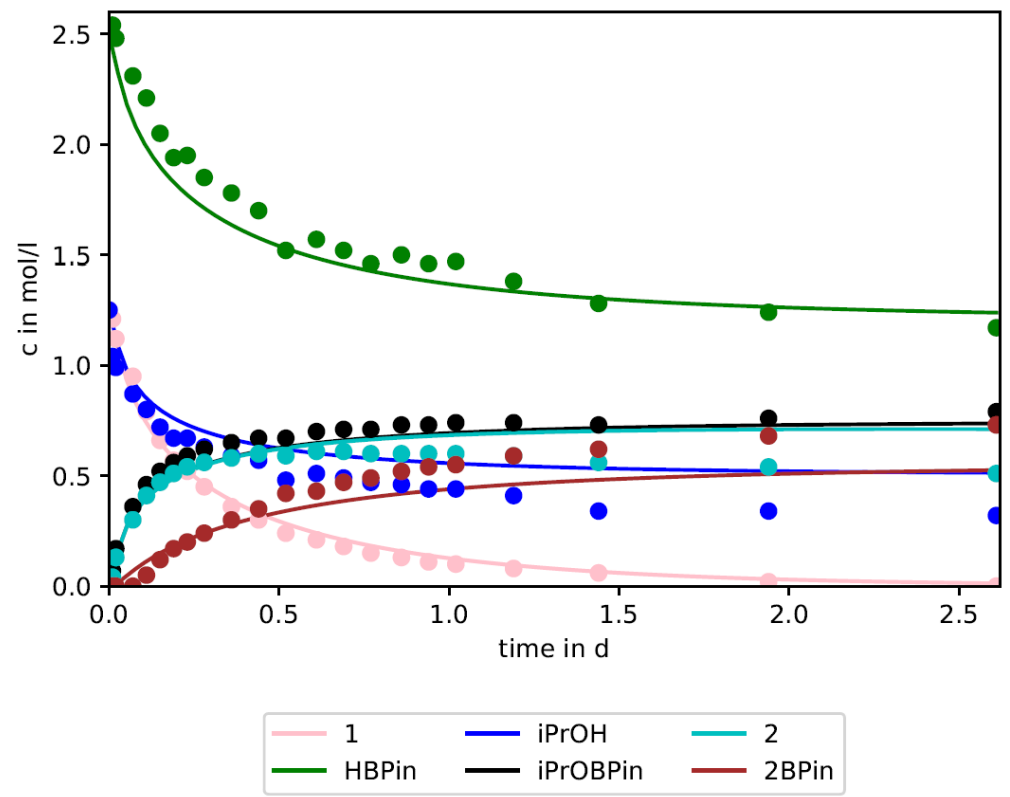

Figure S1: $\quad$ Measured concentration profiles (dots) vs. results from our kinetic model (lines) for the fit with $\mathrm{SE}=0.96 \mathrm{~mol}^{2} \mathrm{l}^{-2}$. 


\section{lodide activation}

Figure S2 shows the results of the kinetic model (no optimization, simply an integration) based on a barrier of $118 \mathrm{~kJ} \mathrm{~mol}^{-1}$ for $\mathbf{R 2}$, which is obtained from DFT data considering an activation of the hydride transfer by iodide instead of chloride. The data show clearly that no reaction takes place with these barriers.

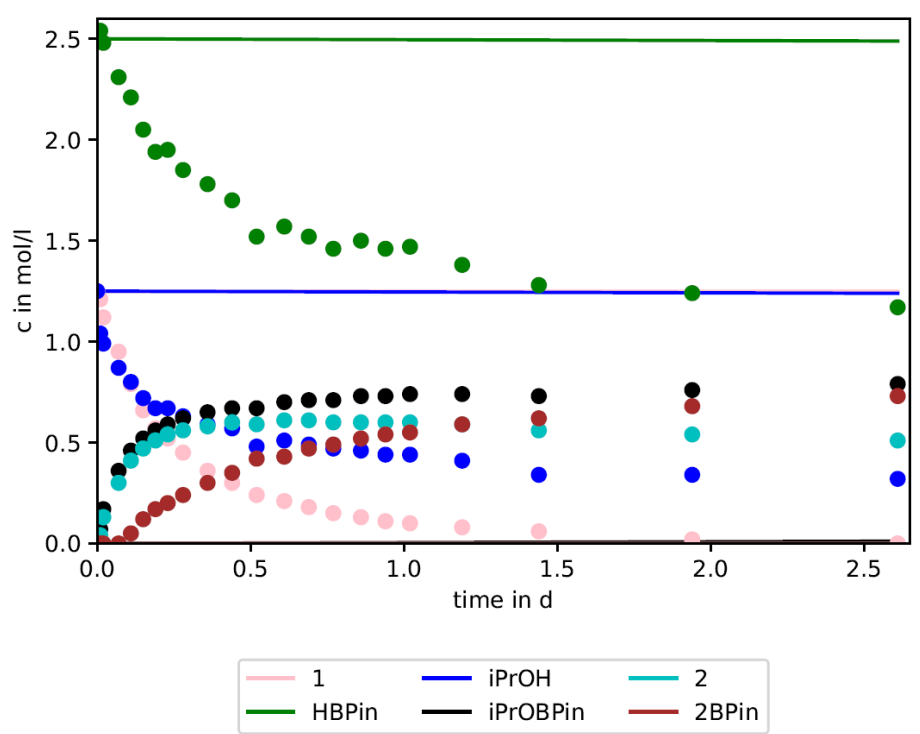

Figure S2: $\quad$ Measured concentration profiles (dots) vs. results from our kinetic model based on barriers obtained from DFT data for activation by iodide instead of chloride (lines). 


\section{Enantioselective Kinetic Model}

Kinetic Model

The elementary reactions used for the enantioselective kinetic model are:

\begin{tabular}{|c|c|}
\hline Label & Reaction \\
\hline & Catalyst Generation \\
\hline R1 & Cat $+\mathrm{THF}+1 \longrightarrow \mathrm{A}+\mathrm{Cl}^{-}$ \\
\hline R2.1 & $\mathrm{A}+\mathrm{HBPin} \longrightarrow \mathrm{B}$ \\
\hline $\mathrm{R} 2.2$ & $\mathrm{~A}+\mathrm{HBPin} \longrightarrow \mathrm{B}^{\prime}$ \\
\hline R3.1 & $\mathrm{B}+\mathrm{iPrOH} \longrightarrow \mathrm{C}+\mathrm{iPrOBPin}$ \\
\hline R3.2 & $\mathrm{B}^{\prime}+\mathrm{iPrOH} \longrightarrow \mathrm{C}^{\prime}+\mathrm{iPrOBPin}$ \\
\hline $\mathrm{R} 4.1$ & $\mathrm{~B}+2 \longrightarrow \mathrm{C}+2 \mathrm{BPin}$ \\
\hline $\mathrm{R} 4.2$ & $\mathrm{~B}^{\prime}+2 \longrightarrow \mathrm{C}^{\prime}+2 \mathrm{BPin}$ \\
\hline $\mathrm{R} 4.3$ & $\mathrm{~B}+2^{\prime} \longrightarrow \mathrm{C}+2 \mathrm{BPin}$ \\
\hline $\mathrm{R} 4.4$ & $\mathrm{~B}^{\prime}+2{ }^{\prime} \longrightarrow \mathrm{C}^{\prime}+2 \mathrm{BPin}$ \\
\hline
\end{tabular}

\begin{tabular}{lc}
\hline Label & Reaction \\
\hline & Catalyst Regeneration \\
R5.1 & $\mathrm{C}+1 \longrightarrow 2+\mathrm{A}$ \\
R5.2 & $\mathrm{C}^{\prime}+1 \longrightarrow 2^{\prime}+\mathrm{A}$ \\
$\mathbf{R} 6.1$ & $2+\mathrm{A} \longrightarrow \mathrm{C}+1$ \\
R6.2 & $2^{\prime}+\mathrm{A} \longrightarrow \mathrm{C}^{\prime}+1$ \\
& Side Reactions \\
R7 & iPrOH + HBPin $\stackrel{\mathrm{Cl}^{-}}{\longrightarrow}$ iPrOBPin $+\mathrm{H}_{2}$ \\
R8.1 & $2+\mathrm{HBPin} \stackrel{\mathrm{Cl}^{-}}{\longrightarrow} 2 \mathrm{BPin}+\mathrm{H}_{2}$ \\
R8.2 & $2^{\prime}+\mathrm{HBPin} \stackrel{\mathrm{Cl}^{-}}{\longrightarrow} 2 \mathrm{BPin}+\mathrm{H}_{2}$
\end{tabular}

Herein, B' and C' denote the states that lead to the minor enantiomer 2'. To avoid overfitting of the kinetic model, the numbers of parameters to be fitted is kept to a minimum. Therefore, the following simplifications were made:

1. The barriers to form $2 \mathrm{BP}$ in and 2 'BPin are similar. As these reactions are anyways fast, they don't determine the kinetic model and the enantioselectivity.

2. A and $A^{\prime}$ can be converted into one another very fast. This assumption is verified by a scan of the rotation of the acetophenone around its carbonyl group when coordinated to the catalyst, shown in Figure S3. The scan was performed on a M06-2x/def2-SVP level followed by single point calculations on the optimized geometries on M06-2x/def2-TZVP/COSMO level of theory:

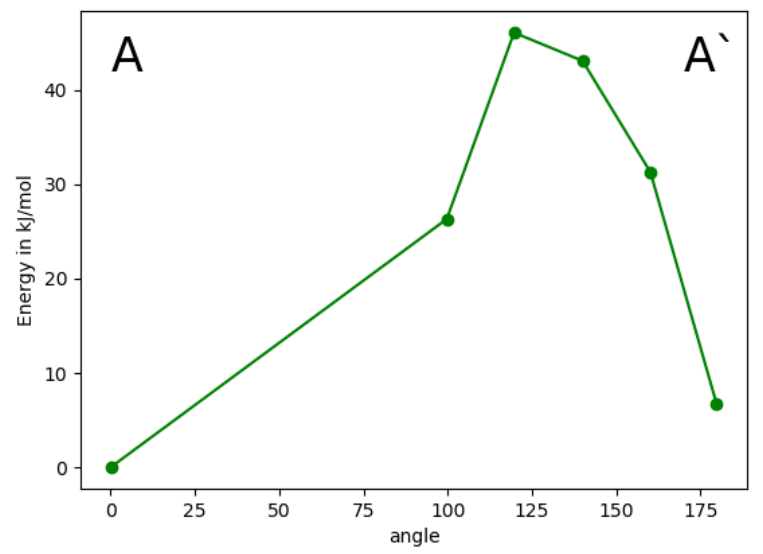

Figure S3: $\quad$ Scan of the conversion of A to A'.

A barrier of $46.1 \mathrm{~kJ} \mathrm{~mol}^{-1}$ is found, which is small in comparison to $81.7 \mathrm{~kJ} \mathrm{~mol}^{-1}$ for the reaction $\mathrm{A}+\mathrm{HBP}$ in to $\mathrm{B}$ or $\mathrm{A}^{\prime}+\mathrm{HBP}$ in to $\mathrm{B}$ '. 


\section{Differential equations}

The set of ordinary differential equations (ODEs) that are derived from the above kinetic model is:

$$
\begin{aligned}
& \frac{d[1]}{d t}=-k_{\mathrm{R} 1}[\mathrm{Cat}][1]-k_{\mathrm{R} 5.1}[\mathrm{C}][1]-k_{\mathrm{R} 5.2}\left[\mathrm{C}^{\prime}\right][1]+k_{\mathrm{R} 6.1}[\mathrm{~A}][2]+k_{\mathrm{R} 6.2}[\mathrm{~A}]\left[2^{\prime}\right] \\
& \frac{d[\mathrm{~A}]}{d t}=k_{\mathrm{R} 1}[\mathrm{Cat}][1]-k_{\mathrm{R} 2.1}[\mathrm{~A}][\mathrm{HBPin}]-k_{\mathrm{R} 2.2}[\mathrm{~A}][\mathrm{HBPin}]+k_{\mathrm{R} 5.1}[\mathrm{C}][1] \\
& +k_{\mathrm{R} 5.2}\left[\mathrm{C}^{\prime}\right][1]-k_{\mathrm{R} 6.1}[\mathrm{~A}][2]-k_{\mathrm{R} 6.2}[\mathrm{~A}]\left[2^{\prime}\right] \\
& \frac{d[\mathrm{HBPin}]}{d t}=-k_{\mathrm{R} 2.1}[\mathrm{~A}][\mathrm{HBPin}]-k_{\mathrm{R} 2.2}[\mathrm{~A}][\mathrm{HBPin}]-k_{\mathrm{R} 7}[\mathrm{PrOH}]\left[\mathrm{Cl}^{-}\right] \\
& -k_{\mathrm{R} 8.1}[11][2]-k_{\mathrm{R} 8.2}[11]\left[2^{\prime}\right] \\
& \frac{d[\mathrm{~B}]}{d t}=k_{\mathrm{R} 2.1}[\mathrm{~A}][\mathrm{HBPin}]-k_{\mathrm{R} 3.1}[\mathrm{~B}][\mathrm{iPrOH}]-k_{\mathrm{R} 4.1}[\mathrm{~B}][2]-k_{\mathrm{R} 4.3}[\mathrm{~B}]\left[2^{\prime}\right] \\
& \frac{d\left[\mathrm{~B}^{\prime}\right]}{d t}=k_{\mathrm{R} 2.2}[\mathrm{~A}][\mathrm{HBPin}]-k_{\mathrm{R} 3.2}\left[\mathrm{~B}^{\prime}\right][\mathrm{PrOH}]-k_{\mathrm{R} 4.2}\left[\mathrm{~B}^{\prime}\right][2]-k_{\mathrm{R} 4.4}\left[\mathrm{~B}^{\prime}\right]\left[2^{\prime}\right] \\
& \frac{d[\mathrm{iPrOH}]}{d t}=-k_{\mathrm{R} 3.1}[\mathrm{~B}][\mathrm{iPrOH}]-k_{\mathrm{R} 3.2}\left[\mathrm{~B}^{\prime}\right][\mathrm{iPrOH}]-k_{\mathrm{R} 7}[\mathrm{iPrOH}]\left[\mathrm{Cl}^{-}\right] \\
& \frac{d[\mathrm{C}]}{d t}=k_{\mathrm{R} 3.1}[\mathrm{~B}][\mathrm{iPrOH}]+k_{\mathrm{R} 4.1}[\mathrm{~B}][2]+k_{\mathrm{R} 4.3}[\mathrm{~B}]\left[2^{\prime}\right]-k_{\mathrm{R} 5.1}[\mathrm{C}][1]+k_{\mathrm{R} 6.1}[\mathrm{~A}][2] \\
& \frac{d\left[\mathrm{C}^{\prime}\right]}{d t}=k_{\mathrm{R} 3.2}\left[\mathrm{~B}^{\prime}\right][\mathrm{iPrOH}]+k_{\mathrm{R} 4.2}\left[\mathrm{~B}^{\prime}\right][2]+k_{\mathrm{R} 4.4}\left[\mathrm{~B}^{\prime}\right]\left[2^{\prime}\right]-k_{\mathrm{R} 5.2}\left[\mathrm{C}^{\prime}\right][1]+k_{\mathrm{R} 6.2}[\mathrm{~A}]\left[2^{\prime}\right] \\
& \frac{d[\mathrm{iPrOBPin}]}{d t}=k_{\mathrm{R} 3.1}[\mathrm{~B}][\mathrm{iPrOH}]+k_{\mathrm{R} 3.2}\left[\mathrm{~B}^{\prime}\right][\mathrm{iPrOH}]+k_{\mathrm{R} 7}[\mathrm{PPrOH}]\left[\mathrm{Cl}^{-}\right] \\
& \frac{d[2]}{d t}=-k_{\mathrm{R} 4.1}[\mathrm{~B}][2]-k_{\mathrm{R} 4.2}\left[\mathrm{~B}^{\prime}\right][2]+k_{\mathrm{R} 5.1}[\mathrm{C}][1]-k_{\mathrm{R} 6.1}[\mathrm{~A}][2]-k_{\mathrm{R} 8.1}\left[\mathrm{Cl}^{-}\right][2] \\
& \frac{d\left[2^{\prime}\right]}{d t}=-k_{\mathrm{R} 4.3}[\mathrm{~B}]\left[2^{\prime}\right]-k_{\mathrm{R} 4.4}\left[\mathrm{~B}^{\prime}\right]\left[2^{\prime}\right]+k_{\mathrm{R} 5.2}\left[\mathrm{C}^{\prime}\right][1]-k_{\mathrm{R} 6.2}[\mathrm{~A}]\left[2^{\prime}\right]-k_{\mathrm{R} 8.2}\left[\mathrm{Cl}^{-}\right]\left[2^{\prime}\right] \\
& \frac{d[2 \mathrm{BPin}]}{d t}=k_{\mathrm{R} 4.1}[\mathrm{~B}][2]+k_{\mathrm{R} 4.2}\left[\mathrm{~B}^{\prime}\right][2]+k_{\mathrm{R} 4.3}[\mathrm{~B}]\left[2^{\prime}\right]+k_{\mathrm{R} 4.4}\left[\mathrm{~B}^{\prime}\right]\left[2^{\prime}\right] \\
& +k_{\mathrm{R} 8.1}\left[\mathrm{Cl}^{-}\right][2]+k_{\mathrm{R} 8.2}\left[\mathrm{Cl}^{-}\right]\left[2^{\prime}\right] \\
& \frac{d[\mathrm{Cat}]}{d t}=-k_{\mathrm{R} 1}[\mathrm{Cat}][1] \\
& \frac{d\left[\mathrm{Cl}^{-}\right]}{d t}=k_{\mathrm{R} 1}[\mathrm{Cat}][1]
\end{aligned}
$$

with the stationary state conditions for B and B':

$$
\begin{aligned}
& {[B]=\frac{k_{\mathrm{R} 2.1}[\mathrm{~A}][\mathrm{HBPin}]}{k_{\mathrm{R} 3.1}[\mathrm{iPrOH}]+k_{\mathrm{R} 4.1}[2]+k_{\mathrm{R} 4.3}\left[2^{\prime}\right]}} \\
& {\left[B^{\prime}\right]=\frac{k_{\mathrm{R} 2.2}[\mathrm{~A}][\mathrm{HBPin}]}{k_{\mathrm{R} 3.2}[\mathrm{iPrOH}]+k_{\mathrm{R} 4.2}[2]+k_{\mathrm{R} 4.4}\left[2^{\prime}\right]}}
\end{aligned}
$$




\section{Results of the kinetic model}

The results of our enantioselective kinetic model is shown in Figure S4. An enlarged representation of 2 ' is given in the main paper.

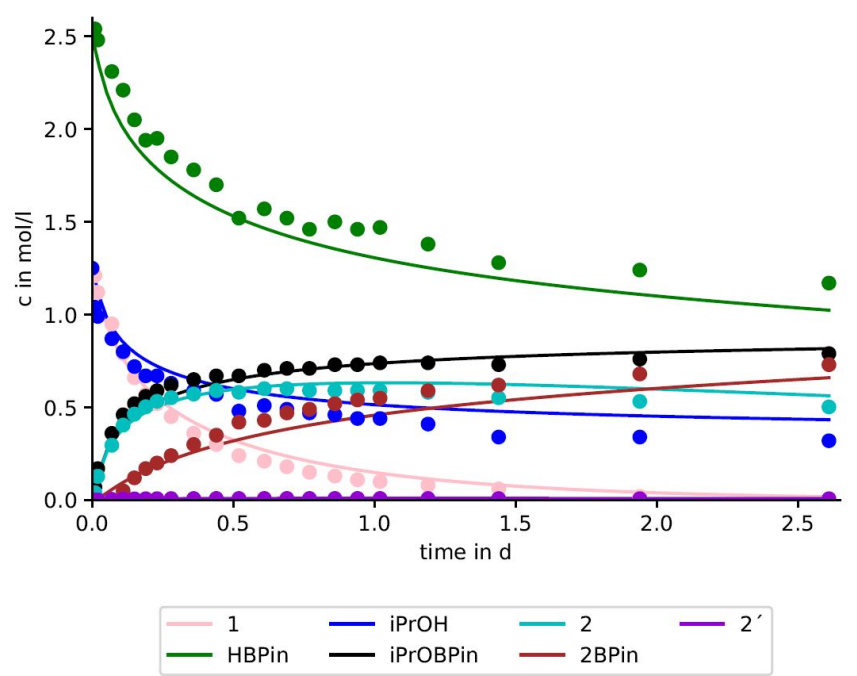

Figure S4: $\quad$ Measured concentration profiles (dots) vs. results from our enantioselective kinetic model (lines).

\section{Sensitivity towards the $\Delta \Delta G$ value}

To investigate how reliably the value $\Delta \Delta G=\Delta G(R 2.2)-\Delta G(R 2.1)$ can be extracted from the kinetic model, $\Delta \mathrm{G}(\mathrm{R} 2.2)$ was varied while $\Delta \mathrm{G}(\mathrm{R} 2.1)$ was fixed to a value of $77.5 \mathrm{~kJ} \mathrm{~mol}^{-1}$ and the influence on the concentration of the minor enantiomer was investigated. Experimental values for 2' were obtained by splitting up the measured concentrations of 2 according to an enantiomeric excess of $97 \%$ in 2 and $2^{\prime}$.

As shown in Figure $\mathrm{S} 5$, a $\Delta \Delta \mathrm{G}$ value of 10.37 , which also results from the formula

$$
e e=\frac{1-\exp \left(-\frac{\Delta \Delta \mathrm{G}}{R T}\right)}{1+\exp \left(-\frac{\Delta \Delta \mathrm{G}}{R T}\right)}
$$

for the experimental value of $97 \%$, fits best to the measured concentrations of $2^{\prime}$. A decrease or increase of $1 \mathrm{~kJ} \mathrm{~mol}^{-1}$ has already a big influence on the numerical values, which shows the high sensitivity of the kinetic model towards the $\Delta \Delta \mathrm{G}$ value. 


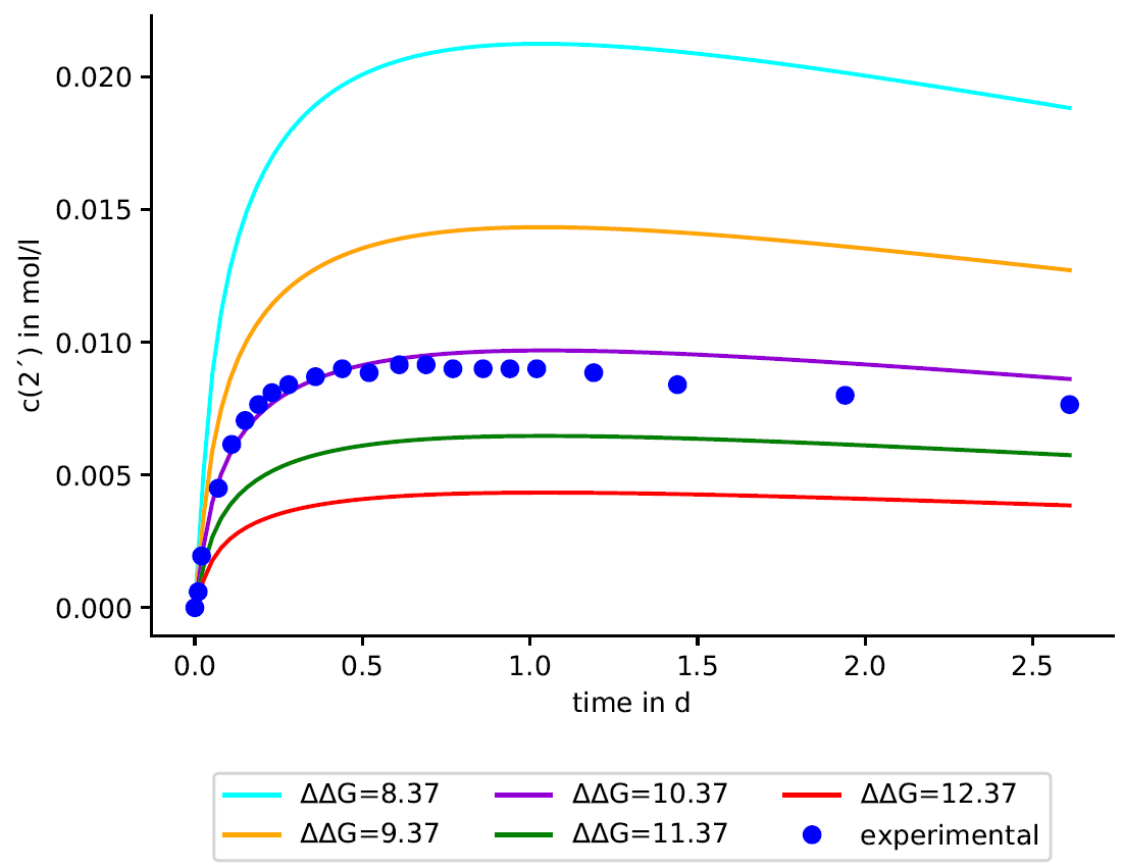

Figure S5: Concentration-time profile of 2' for different $\Delta \Delta \mathrm{G}$ values from the kinetic model (solid lines) compared to the experimental values (dotted line). 


\section{Experimental Investigations}

\section{General Remarks}

Unless otherwise noted, all reactions were performed under a positive pressure of nitrogen ( $0.2 \mathrm{bar})$ in dried glassware (stored at $150{ }^{\circ} \mathrm{C}$ in an oven and subsequently heated to $630^{\circ} \mathrm{C}$ for $5-10$ min under high vacuum using a heat-gun). Liquids were added via syringe, solids were added neat against a flow of nitrogen or as stock solution via syringe. Solvents were removed under reduced pressure using a rotary evaporator with a bath temperature of $40{ }^{\circ} \mathrm{C}$ and pressures between 15-700 mbar. Non-volatile compounds were dried in high vacuum. A cryostatic temperature regulator was used for reactions at low temperatures. Dichloromethane, diethyl ether and tetrahydrofuran used for reactions and for the purification of ligands were dried under nitrogen using a solvent purification system (MBraun MB SPS 800). Dichloromethane and tetrahydrofuran were further purified by degassing for $15 \mathrm{~min}$ with nitrogen and using freeze-pump-thaw cycles. Methanol and isopropanol were purchased in crowncapped bottles from Sigma-Aldrich and were used without further purification. The ligands $\mathbf{L 1},^{[1]}$ $\mathbf{L} 1-\mathbf{C l},{ }^{[2]} \mathbf{L} 1-\mathbf{B r}^{[3]}$ and $\mathbf{L} 1-\mathbf{I}^{[2]}$ were synthesized according to literature known procedures. ${ }^{[1-3]}$ Acetophenone was purchased from Sigma-Aldrich, further purified by distillation under vacuum and stored under nitrogen atmosphere. (R)-1-Phenylethanol was purchased from Fluka, further purified by distillation under vacuum and stored under nitrogen atmosphere. Pinacolborane was purchased from Merck and distilled under nitrogen. Diethylaluminum chloride solution (1.00 M in hexanes) was purchased from Sigma Aldrich and used as is. All other laboratory chemicals were purchased from commercial suppliers and were used without purification unless otherwise noted.

Yields refer to isolated, pure compounds (if not stated otherwise) and were calculated in mol\% of the used starting material. Yields of ${ }^{1} \mathrm{H}-\mathrm{NMR}$ experiments were calculated by addition of mesitylene as an internal standard.

NMR-spectra were recorded at $25{ }^{\circ} \mathrm{C}$ on Bruker Avance spectrometers operating at Lamor frequencies of $300,400,500$ or $700 \mathrm{MHz}\left({ }^{1} \mathrm{H}\right), 75,100,125,175 \mathrm{MHz}\left({ }^{13} \mathrm{C}\right), 125 \mathrm{MHz}\left({ }^{11} \mathrm{~B}\right)$ and $375 \mathrm{MHz}\left({ }^{19} \mathrm{~F}\right)$. Deuterated chloroform and THF were dried by distillation over calcium hydride and stored over molecular sieves. Abbreviations for multiplicities are as follows: $s$ (singulet), $d$ (doublet), $t$ (triplet), $q$ (quartet), $m$ (multiplet), br (broad signal), brs (broad singulet). Signals are given by chemical shifts $\delta(\mathrm{ppm})$.

IR-spectra were recorded by the analytical service of the Institut für Organische Chemie der Universität Stuttgart on a Bruker Alpha Spectrometer equipped with an ATR diamond unit and the signals are given by wavenumbers $\left(\mathrm{cm}^{-1}\right)$. Melting points were measured using a Stuart smp40 melting point apparatus in open glass capillaries and are uncorrected. Optical rotation was measured on a Perkin Elmer 241 Polarimeter operating at the sodium D line $(\lambda=589 \mathrm{~nm})$ and mercury lines $\left(\lambda_{1}=578 \mathrm{~nm}\right.$ and $\lambda_{2}=546 \mathrm{~nm}$ ) with a $100 \mathrm{~mm}$ path cell length. Mass spectra were measured by the analytical service of 
the Institut für Organische Chemie der Universität Stuttgart using an ESI-TOF (Bruker MicroTOFQ) or EI-sector field-MS (Finnigan MAT 95) spectrometer. 


\section{General Procedures}

\section{General Procedure for the In-Situ Formation of AI-Salen-Catalysts (GP1)}
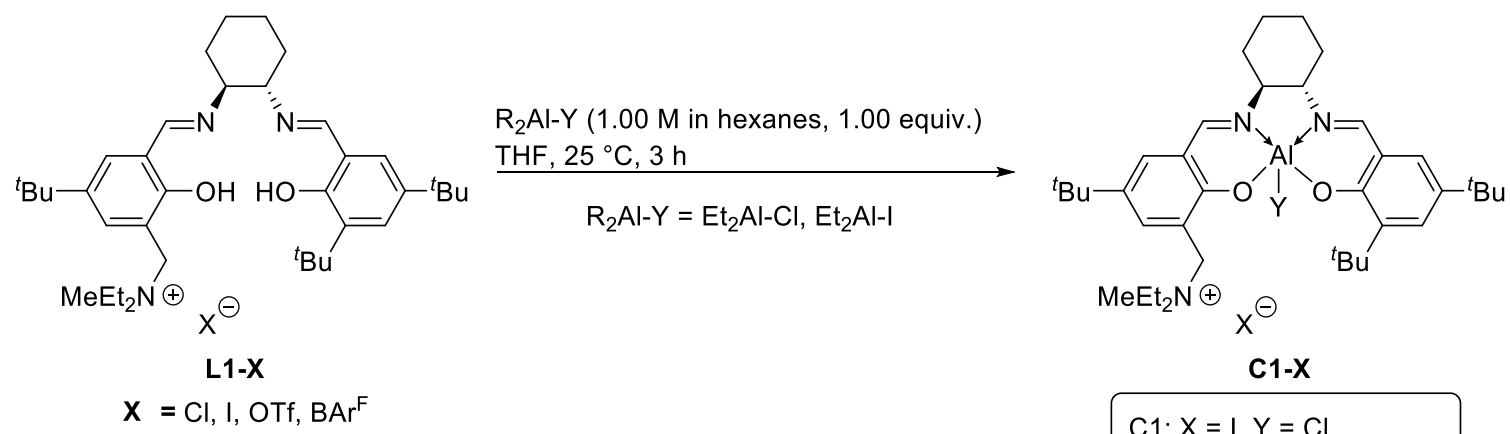

\begin{tabular}{|l} 
C1-X \\
C1: $X=I, Y=C l$ \\
C1-Cl: $X=\mathrm{Cl}, Y=\mathrm{Cl}$ \\
C1-BAr $\mathrm{F}: \mathrm{X}=\mathrm{BAr} F, \mathrm{Y}=\mathrm{Cl}$ \\
C1-OTf $\mathrm{X}=\mathrm{OTf}, \mathrm{Y}=\mathrm{Cl}$ \\
C1-I: $\mathrm{X}=\mathrm{I}, \mathrm{Y}=\mathrm{I}$ \\
$\mathrm{C} 1-\mathrm{I} 2: \mathrm{X}=\mathrm{Cl}, \mathrm{Y}=\mathrm{I}$
\end{tabular}

Following a literature procedure, ${ }^{[2]}$ the ligand L1-X (1.00 equiv.) was dissolved in dry THF $(8.34 \mu \mathrm{moL} / \mathrm{mL})$ and the corresponding aluminum source $(1.00 \mathrm{M}$ in hexanes, 1.00 equiv.) was subsequently added. Afterwards the glass wall was rinsed with dry THF (making it a $4.17 \mu \mathrm{moL} / \mathrm{mL}$ solution). The reaction solution was stirred at room temperature for $3 \mathrm{~h}$. Complete complexation of the ligand was verified by ${ }^{1} \mathrm{H}-\mathrm{NMR}$ spectroscopy. The reaction solution was used as stock solution for following reactions without further purification.

\section{General Procedure for the Continuous Reaction Monitoring of the Esterification of Pinacolborane with Secondary Alcohols in the Absence of Halide lons (GP2)}

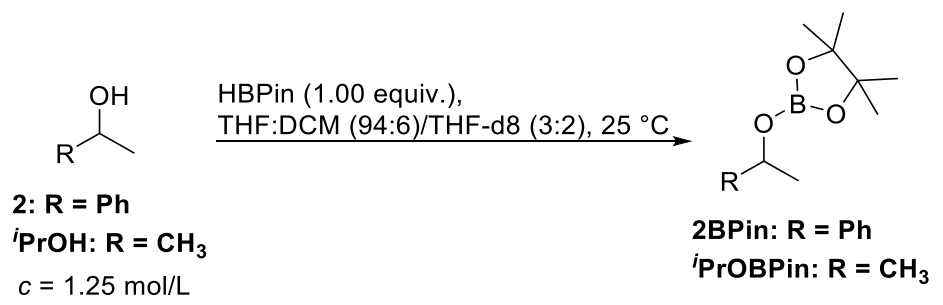

For the continuous reaction monitoring in the absence of halide ions, the corresponding secondary alcohol (0.50 mmol, 1.0 equiv.), a solvent mixture of dry THF:DCM (94:6, 160-174 $\mu \mathrm{L})$ and pinacolborane ( $64.0 \mathrm{mg}, 73 \mu \mathrm{L}, 0.5 \mathrm{mmol}, 1.0$ equiv.) were added directly to a graduated Young-NMR vial. Subsequently, the glass wall was rinsed with dry THF-d8 making it a $1.25 \mathrm{~mol} / \mathrm{L}$ solution in terms of the secondary alcohol. The sample was then continuously monitored by ${ }^{1} \mathrm{H}-\mathrm{NMR}$ spectroscopy. 
General Procedure for the Continuous Reaction Monitoring of the Esterification of Pinacolborane with Secondary Alcohols using TBAX Salts as Halide Sources (GP3)

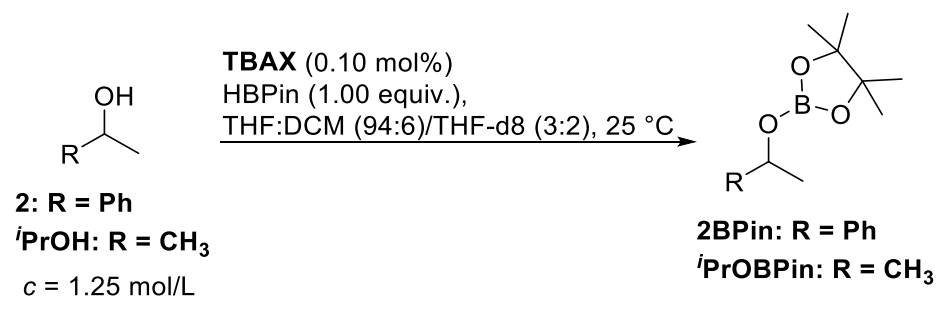

For the continuous reaction monitoring using tetrabutylammonium salts as halide sources, the corresponding secondary alcohol $(0.50 \mathrm{mmol}, 1.0$ equiv.), freshly prepared TBAX stock solution $(0.50 \mu \mathrm{moL}, 0.10 \mathrm{~mol} \%, 160 \mu \mathrm{L}, 3.13 \mu \mathrm{moL} / \mathrm{mL}$ in THF:DCM (94:6)) and pinacolborane (64.0 mg, $73 \mu \mathrm{L}, 0.5 \mathrm{mmol}, 1.0$ equiv.) were added directly to a graduated Young-NMR vial. Subsequently, the glass wall was rinsed with dry THF-d8 making it a $1.25 \mathrm{~mol} / \mathrm{L}$ solution in terms of the secondary alcohol. The sample was then continuously monitored by ${ }^{1} \mathrm{H}-\mathrm{NMR}$ spectroscopy.

General Procedure for the Continuous Reaction Monitoring of the Esterification of Pinacolborane with Secondary Alcohols using Lewis Acid/ Onium Salt Catalysts as Halide Sources (GP4)
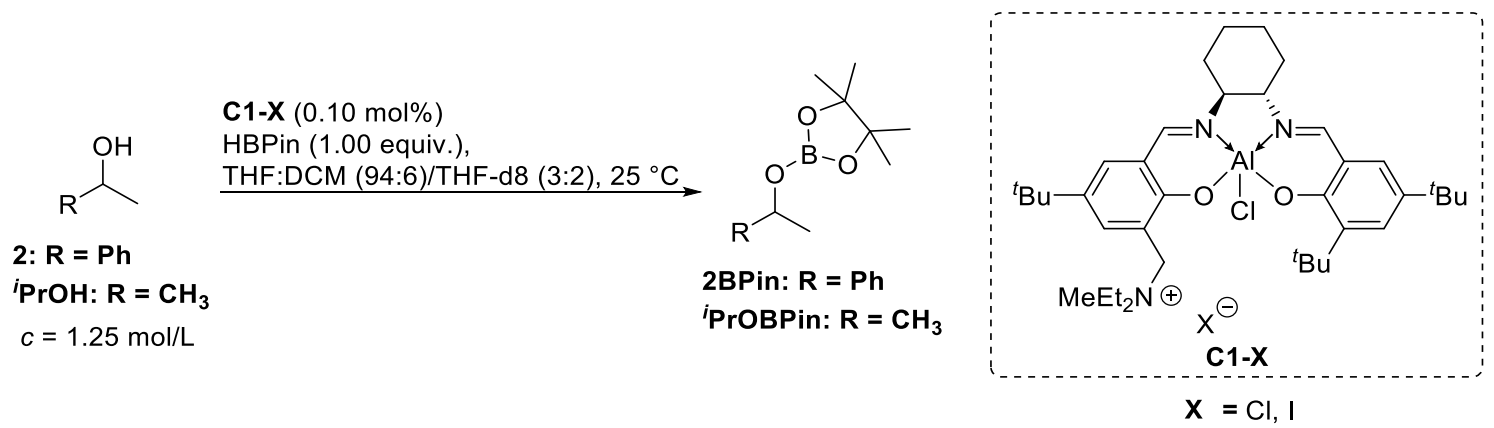

For the continuous reaction monitoring, using Lewis acid/onium salt catalysts as halide sources, the corresponding catalyst C1-X was freshly prepared according to GP1. Then, the corresponding secondary alcohol $(0.50 \mathrm{mmol}, 1.0$ equiv. $)$, catalyst $\mathbf{C 1 - X}(0.50 \mu \mathrm{moL}, \quad 0.10 \mathrm{~mol} \%, 120 \mu \mathrm{L}$ $4.17 \mu \mathrm{moL} / \mathrm{mL}$ in THF), dry THF $(30-44 \mu \mathrm{L})$, dry DCM $(10 \mu \mathrm{L})$ and pinacolborane $(64.0 \mathrm{mg}, 73 \mu \mathrm{L}$, $0.5 \mathrm{mmol}, 1.0$ equiv.) were added directly to a graduated Young-NMR vial. Subsequently, the glass wall was rinsed with dry THF-d8 making it a $1.25 \mathrm{~mol} / \mathrm{L}$ solution in terms of the secondary alcohol. The sample was then continuously monitored by ${ }^{1} \mathrm{H}-\mathrm{NMR}$ spectroscopy. 


\section{Ligand Synthesis}

\section{1-(5-(tert-Butyl)-3-((E)-(((1S,2S)-2-(((E)-3,5-di-tert-butyl-2-}

\section{hydroxybenzylidene)amino)cyclohexyl)imino)methyl)-2-hydroxybenzyl)-N,N-diethyl-N-}

methylmethanammonium Triflate (L1-OTf)
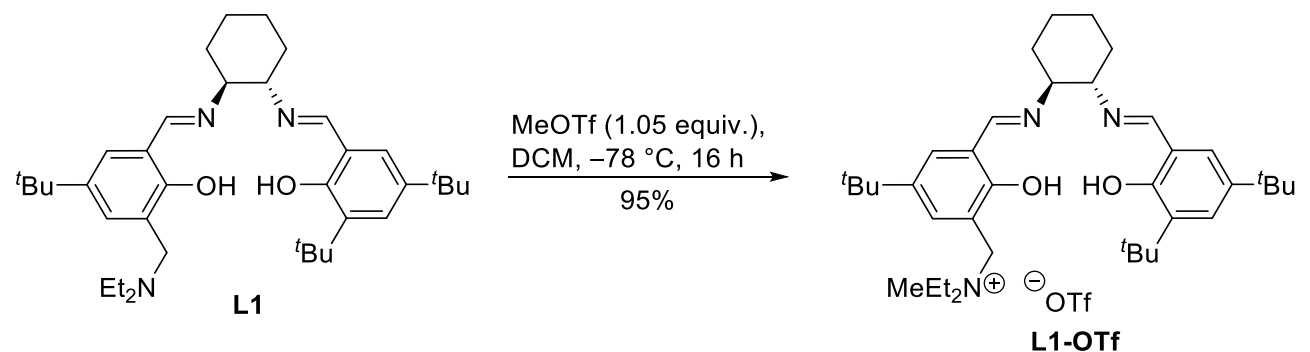

According to a literature known procedure, ${ }^{[1]}$ the ligand $\mathbf{L 1}(153.7 \mathrm{mg}, 0.27 \mathrm{mmol}, 1.00$ equiv.) was dissolved in dry DCM $(3 \mathrm{~mL})$ and the solution was cooled down to $-78^{\circ} \mathrm{C}$. The solution was treated with methyl triflate ( $1.50 \mathrm{M}$ in benzene, $46.0 \mathrm{mg}, 188 \mu \mathrm{L}, 0.28 \mathrm{mmol}, 1.05$ equiv.) and was stirred at $-78{ }^{\circ} \mathrm{C}$ for $16 \mathrm{~h}$. After complete conversion, the reaction solution was allowed to warm up to room temperature and methanol $(0.5 \mathrm{~mL})$ was added. The reaction solution was stirred at room temperature for $30 \mathrm{~min}$ to neutralize remaining alkylation reagent. The solvent was removed under reduced pressure and the residue was washed with $n$-pentane. The ligand L1-OTf (187.2 mg, $0.25 \mathrm{mmol}, 95 \%)$ was obtained as yellow solid.

$\mathbf{C}_{39} \mathbf{H}_{60} \mathbf{F}_{3} \mathbf{N}_{3} \mathbf{O}_{5}$ S. MG: $739.98 \mathrm{~g} / \mathrm{mol}$. [ $\boldsymbol{\alpha}^{\mathbf{2 0}}{ }_{\mathbf{D}}$ : $288.4\left(c=1.0 \mathrm{mg} / \mathrm{mL}, \mathrm{CHCl}_{3}\right.$, sample with $\left.>99 \% e e\right)$. Smp.: $121.8-122.5^{\circ} \mathrm{C} .{ }^{1} \mathbf{H}-\mathrm{NMR}\left(500 \mathrm{MHz}, \mathrm{CDCl}_{3}, 25^{\circ} \mathrm{C}\right): \delta=14.35$ (brs, $\left.1 \mathrm{H}, \mathrm{OH}\right), 13.62$ (brs, $1 \mathrm{H}$, $\mathrm{O} H), 8.36(s, 1 \mathrm{H}, \mathrm{C} H \mathrm{~N}), 8.30(s, 1 \mathrm{H}, \mathrm{C} H \mathrm{~N}), 7.53\left(d, J=2.4 \mathrm{~Hz}, 1 \mathrm{H}, H_{\text {ar. }}\right), 7.34\left(d, J=2.4 \mathrm{~Hz}, 1 \mathrm{H}, H_{\text {ar. }}\right)$, $7.29\left(d, J=2.4 \mathrm{~Hz}, 1 \mathrm{H}, H_{\text {ar. }}\right), 7.01\left(d, J=2.4 \mathrm{~Hz}, 1 \mathrm{H}, H_{\text {ar. }}\right), 4.52-4.44\left(m, 2 \mathrm{H}, \mathrm{CH}_{2}\right), 3.54-3.40(m, 3 \mathrm{H}$, $\left.\mathrm{NCH}_{2} \mathrm{CH}_{3}, \mathrm{CyCH}\right), 3.39-3.26\left(m, 3 \mathrm{H}, \mathrm{NCH}_{2} \mathrm{CH}_{3}, \mathrm{CyCH}\right), 2.94(s, 3 \mathrm{H}, \mathrm{NCH}), 2.06-1.98(m, 1 \mathrm{H}$, $\left.\mathrm{CyCH}_{2}\right), 1.98-1.85\left(m, 3 \mathrm{H}, \mathrm{CyCH}_{2}\right), 1.82-1.61\left(m, 2 \mathrm{H}, \mathrm{CyCH} \mathrm{H}_{2}\right), 1.54-1.38\left(m, 15 \mathrm{H}, \mathrm{N}\left(\mathrm{CH}_{2} \mathrm{CH}_{3}\right)_{2}\right.$, $\left.\mathrm{C}\left(\mathrm{CH}_{3}\right)_{3}\right), 1.25\left(s, 9 \mathrm{H}, \mathrm{C}\left(\mathrm{CH}_{3}\right)_{3}\right), 1.24\left(s, 9 \mathrm{H}, \mathrm{C}\left(\mathrm{CH}_{3}\right)_{3}\right)$ ppm. ${ }^{13} \mathbf{C}-\mathbf{N M R}\left(125 \mathrm{MHz}, \mathrm{CDCl}_{3}, 25{ }^{\circ} \mathrm{C}\right)$ : $\delta=165.9,164.8,160.1,158.1,141.8,140.3,136.8,135.6,131.3,127.1,125.9,122.2,118.4,117.9$, 114.4, 72.4, 71.6, 59.9, 56.0, 55.9, 46.7, 35.1, 34.2, 34.1, 33.6, 32.7, 31.6, 31.2, 29.5, 24.4, 24.3, 8.4 ppm. ${ }^{19}$ F-NMR (375 MHz, $\left.\mathrm{CDCl}_{3}, 25^{\circ} \mathrm{C}\right): \delta=-78.3 \mathrm{ppm}$. IR (solid): $\tilde{v}=2953,2863,1628,1467,1393$, 1363, 1254, 1223, 1149, 1029, 935, 879, 804, 637, 572, 517. HRMS (ESI) $m / z$ : calculated for $\mathrm{C}_{33} \mathrm{H}_{47} \mathrm{~N}_{2} \mathrm{O}_{2}\left[\mathrm{M}^{+}-\mathrm{C}_{6} \mathrm{H}_{13} \mathrm{~F}_{3} \mathrm{NO}_{3} \mathrm{~S}\right]:$ 503.3632; found: 503.3620 . 


\section{N-(5-(tert-Butyl)-3-((E)-(((1S,2S)-2-(((E)-3,5-di-tert-butyl-2-hydroxybenzylidene)amino)-}

cyclohexyl)imino)methyl)-2-hydroxybenzyl)-N-diethyl-Nmethylmethanammonium Tetrakis[3,5-bis(trifluoromethyl)phenyl]borate (L1-BArF)
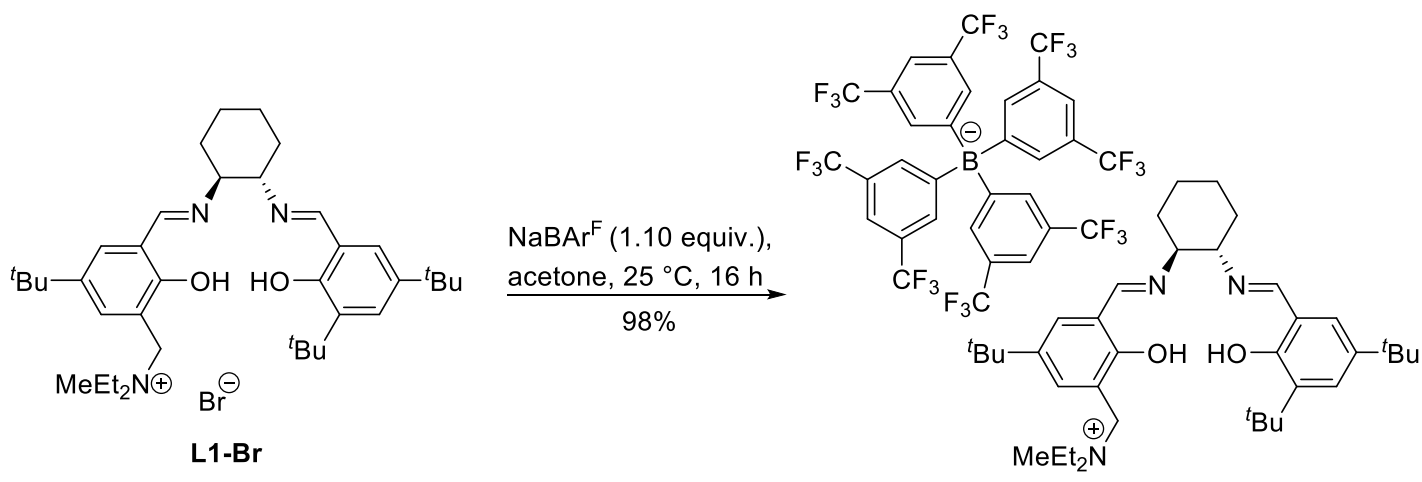

L1-BAr ${ }^{\mathrm{F}}$

The ligand L1-Br (31.0 mg, $46 \mu \mathrm{mol}, 1.00$ equiv.) was dissolved in dry acetone and sodium tetrakis[3,5bis(trifluoromethyl)phenyl]borate ( $45.0 \mathrm{mg}, 50 \mu \mathrm{mol}, 1.10$ equiv.) was added. The reaction solution was stirred at room temperature for $16 \mathrm{~h}$. Then, DCM was added and the reaction solution was filtrated over celite. The solvent of the filtrate was removed under reduced pressure. The ligand $\mathbf{L 1 - B A r ^ { \mathbf { F } }}(65.1 \mathrm{mg}$, $45 \mu \mathrm{mol}, 98 \%$ ) was obtained as a yellow solid.

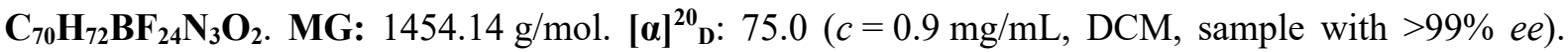
Smp.: $110{ }^{\circ} \mathrm{C} .{ }^{1} \mathbf{H}-\mathbf{N M R}\left(400 \mathrm{MHz}, \mathrm{CDCl}_{3}, 25^{\circ} \mathrm{C}\right): \delta=14.78$ (brs, $\left.1 \mathrm{H}, \mathrm{OH}\right), 13.54$ (brs $\left., 1 \mathrm{H}, \mathrm{OH}\right), 8.39$ $(s, 1 \mathrm{H}, \mathrm{C} H=\mathrm{N}), 8.31(s, 1 \mathrm{H}, \mathrm{C} H=\mathrm{N}), 7.75-7.67\left(m, 8 \mathrm{H}, \mathrm{BAr}^{\mathrm{F}} H_{\text {ar. }}\right), 7.59-7.50\left(m, 4 \mathrm{H}, \mathrm{BAr}^{\mathrm{F}} H_{\text {ar. }}\right)$, 7.38-7.34 ( $\left.m, 2 \mathrm{H}, H_{\text {ar. }}\right), 7.17-7.14\left(m, 1 \mathrm{H}, H_{\text {ar. }}\right), 7.04-7.00\left(m, 1 \mathrm{H}, H_{\text {ar. }}\right), 4.25-4.15\left(m, 2 \mathrm{H}, \mathrm{CH}_{2}\right), 3.54-$ $3.45(m, 1 \mathrm{H}, \mathrm{Cy} H), 3.36-3.27(m, 1 \mathrm{H}, \mathrm{Cy} H), 3.21-3.09\left(m, 2 \mathrm{H}, \mathrm{NCH}_{2} \mathrm{CH}_{3}\right), 3.09-2.98(m, 2 \mathrm{H}$, $\left.\mathrm{NCH}_{2} \mathrm{CH}_{3}\right), 2.67\left(s, 3 \mathrm{H}, \mathrm{NCH}_{3}\right), 2.08-1.86(m, 4 \mathrm{H}, \mathrm{Cy} H), 1.79-1.63(m, 2 \mathrm{H}, \mathrm{Cy} H), 1.52-1.46(m, 2 \mathrm{H}$, $\mathrm{Cy} H), 1.40\left(s, 9 \mathrm{H}, \mathrm{CH}_{3}\right), 1.28-1.19\left(m, 24 \mathrm{H}, \mathrm{CH}_{3}+\mathrm{NCH}_{2} \mathrm{CH}_{3}\right)$ ppm. ${ }^{13} \mathbf{C}-\mathbf{N M R}\left(100 \mathrm{MHz}, \mathrm{CDCl}_{3}\right.$, $\left.25^{\circ} \mathrm{C}\right): \delta=165.9,164.5,162.4,161.9,161.4,161.3,160.9,157.9,141.4,140.4,136.8,134.8,133.9$, 132.4, 129.1, 128.8, 128.6, 127.2, 125.9, 125.8, 123.2, 120.5, 118.6, 117.8, 117.5, 112.9, 72.0, 71.4, $61.0,56.1,56.0,46.7,35.0,34.1,33.9,33.5,32.3,31.4,31.0,30.9,30.7,29.3,24.2,24.1,7.8$ ppm. ${ }^{11} \mathbf{B}-\mathbf{N M R} \quad\left(125 \mathrm{MHz}, \quad \mathrm{CDCl}_{3}, \quad 25{ }^{\circ} \mathrm{C}\right): \quad \delta=-6.62 \mathrm{ppm} . \quad{ }^{19} \mathbf{F}-\mathrm{NMR} \quad\left(375 \mathrm{MHz}, \mathrm{CDCl}_{3}, \quad 25{ }^{\circ} \mathrm{C}\right)$ : $\delta=-62.35$ ppm. IR: $\tilde{v}=2961,2866,1632,1609,1354,1275,1123$. HRMS (ESI) $\mathbf{m} / z$ : calculated for $\mathrm{C}_{38} \mathrm{H}_{60} \mathrm{~N}_{3} \mathrm{O}_{2} \quad\left[\mathrm{M}^{+}-\mathrm{C}_{32} \mathrm{H}_{12} \mathrm{BF}_{24}\right]:$ 590.4680; found: 590.4654. calculated for $\mathrm{C}_{32} \mathrm{H}_{12} \mathrm{BF}_{24}$ $\left[\mathrm{M}^{-}-\mathrm{C}_{38} \mathrm{H}_{60} \mathrm{~N}_{3} \mathrm{O}_{2}\right]: 863.07$; found: 863.04. 


\section{Kinetic Experiments}

Continuous Reaction Monitoring of the Esterification of Pinacolborane with (R)-1-Phenylethanol by ${ }^{1} \mathrm{H}-\mathrm{NMR}$ spectroscopy

\section{Reaction Monitoring in the Absence of a Halide Source}
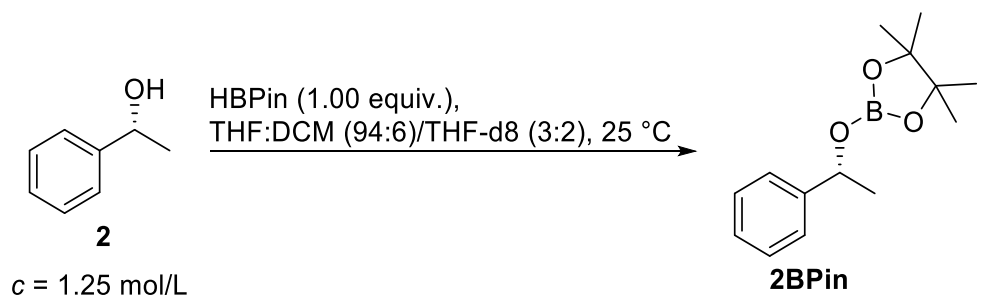

The continuous reaction monitoring was performed according to GP2 using $(R)$-1-phenylethanol 2 (61.1 mg, $60 \mu \mathrm{L}, 0.50 \mathrm{mmol}, 1.00$ equiv.), dry THF:DCM (94:6, $160 \mu \mathrm{L})$ and pinacolborane (64.0 mg, $73 \mu \mathrm{L}, 0.50 \mathrm{mmol}, 1.00$ equiv.).

The recorded data is in accordance with the literature. ${ }^{[4]}$

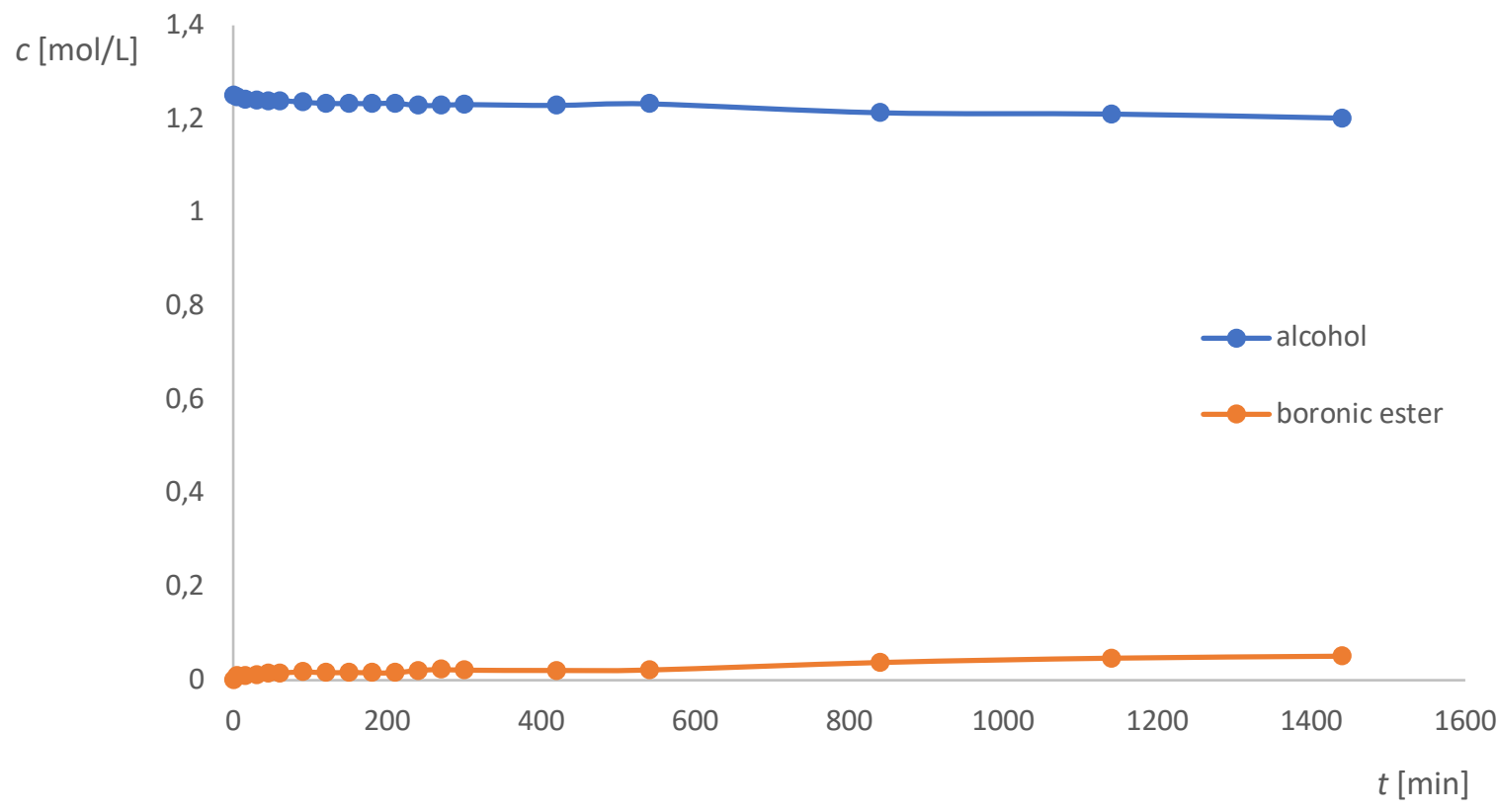

Figure S6: $\quad$ Reaction progress of the esterification of $\mathbf{2}$ in the absence of a halide source.

Under the chosen conditions only $4 \%$ of 2 BPin was formed after a reaction time of $24 \mathrm{~h}$. The concentrations of $\mathbf{2}$ and $\mathbf{2 B P i n}$ were almost constant. 
Table S2: Calculated concentration data for 2 and 2BPin for the reaction progress in the absence of a halide source.

\begin{tabular}{ccc}
\hline$t[\mathrm{~min}]$ & $c(\mathbf{2})[\mathrm{mol} / \mathrm{L}]$ & $c(\mathbf{2 B P i n})[\mathrm{mol} / \mathrm{L}]$ \\
\hline 0 & 1.25 & 0 \\
15 & 1.24 & 0.01 \\
30 & 1.24 & 0.02 \\
45 & 1.24 & 0.02 \\
60 & 1.24 & 0.02 \\
90 & 1.24 & 0.02 \\
120 & 1.23 & 0.02 \\
150 & 1.23 & 0.02 \\
180 & 1.23 & 0.02 \\
210 & 1.23 & 0.02 \\
240 & 1.23 & 0.02 \\
270 & 1.23 & 0.02 \\
300 & 1.23 & 0.02 \\
420 & 1.23 & 0.02 \\
540 & 1.23 & 0.02 \\
840 & 1.21 & 0.04 \\
1140 & 1.21 & 0.05 \\
1440 & 1.20 & 0.05 \\
\hline & &
\end{tabular}




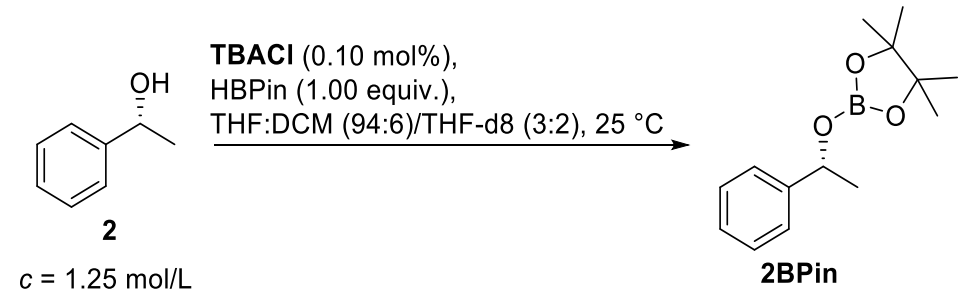

The continuous reaction monitoring was performed according to GP3 using $(R)$-1-phenylethanol 2 (61.1 mg, $60 \mu \mathrm{L}, 0.50 \mathrm{mmol}, 1.00$ equiv.), freshly prepared TBACl stock solution $(0.14 \mathrm{mg}$, $0.50 \mu \mathrm{moL}, 0.10 \mathrm{~mol} \%, 160 \mu \mathrm{L}, 3.13 \mu \mathrm{moL} / \mathrm{mL}$ in THF:DCM (94:6)) and pinacolborane (64.0 mg, $73 \mu \mathrm{L}, 0.50 \mathrm{mmol}, 1.00$ equiv.).

The recorded data is in accordance with the literature. ${ }^{[4]}$

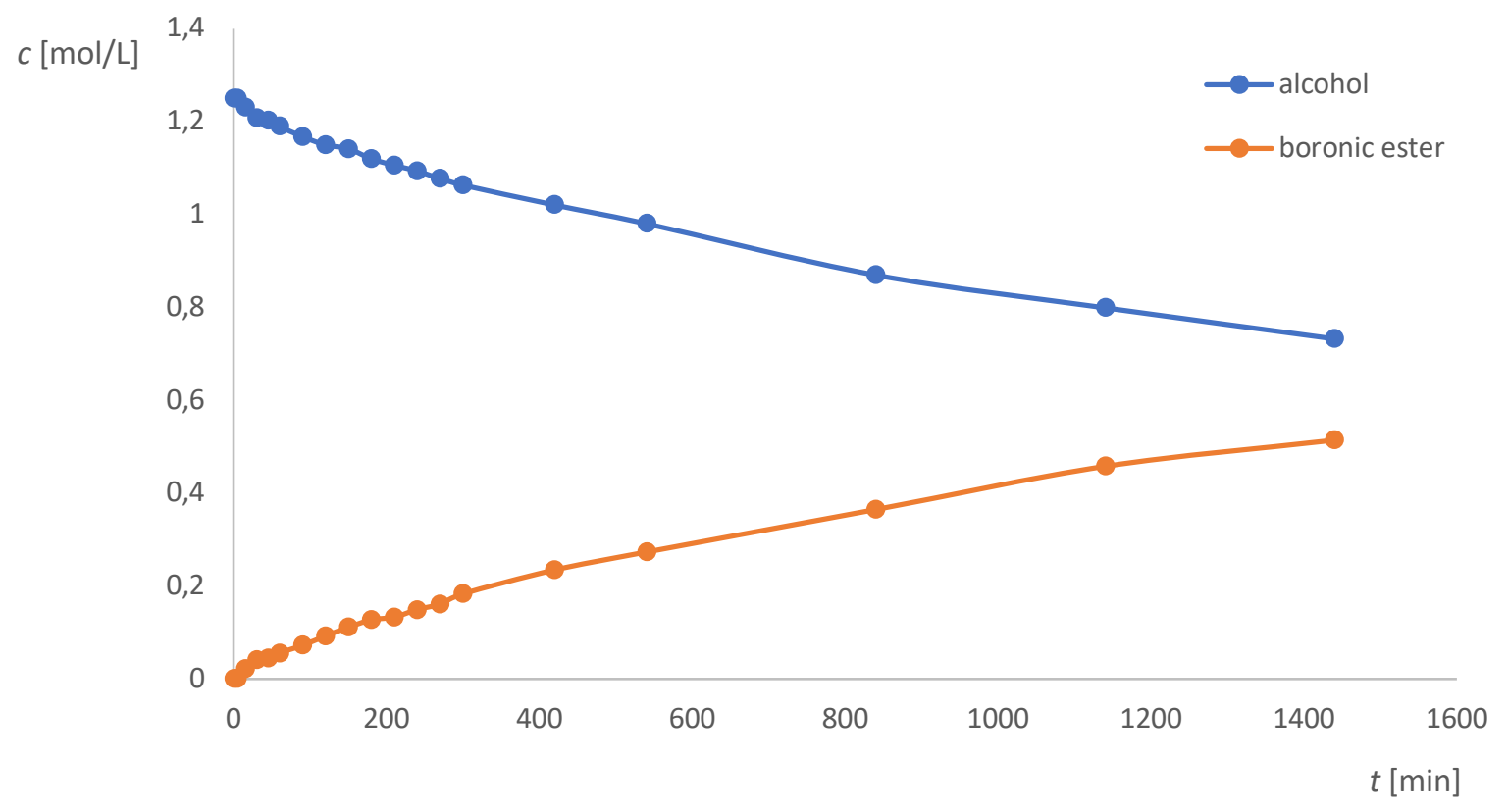

Figure S7: $\quad$ Reaction progress of the esterification of 2 with the addition of TBACl as chloride source.

By adding TBACl as chloride source, $41 \%$ of $\mathbf{2 B P i n}$ was formed after a reaction time of $24 \mathrm{~h}$. The esterification gets accelerated by the addition of chloride ions. 
Table S3: Calculated concentration data for $\mathbf{2}$ and 2BPin for the reaction progress with the addition of TBACI as chloride source.

\begin{tabular}{ccc}
\hline$t[\mathrm{~min}]$ & $c(\mathbf{2})[\mathrm{mol} / \mathrm{L}]$ & $c($ 2BPin $)[\mathrm{mol} / \mathrm{L}]$ \\
\hline 0 & 1.25 & 0 \\
15 & 1.23 & 0.02 \\
30 & 1.21 & 0.04 \\
45 & 1.20 & 0.04 \\
60 & 1.19 & 0.06 \\
90 & 1.17 & 0.07 \\
120 & 1.15 & 0.09 \\
150 & 1.14 & 0.11 \\
180 & 1.12 & 0.13 \\
210 & 1.11 & 0.13 \\
240 & 1.09 & 0.15 \\
270 & 1.08 & 0.16 \\
300 & 1.06 & 0.18 \\
420 & 1.02 & 0.23 \\
540 & 0.98 & 0.27 \\
840 & 0.87 & 0.36 \\
1140 & 0.80 & 0.46 \\
1440 & 0.73 & 0.51 \\
\hline
\end{tabular}




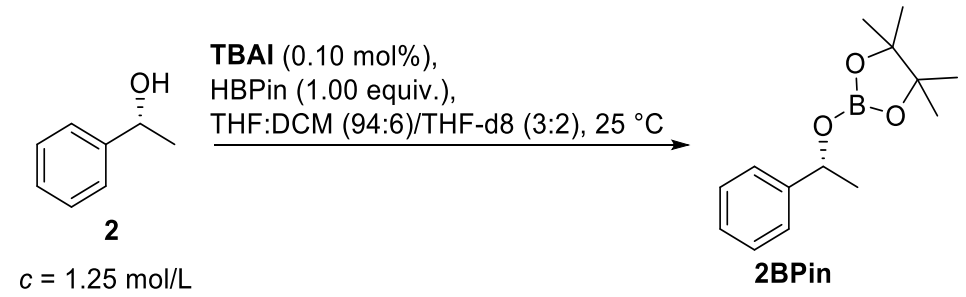

The continuous reaction monitoring was performed according to GP3 using $(R)$-1-phenylethanol 2 (61.1 mg, $60 \mu \mathrm{L}, 0.50 \mathrm{mmol}, 1.00$ equiv.), freshly prepared TBAI stock solution $(0.18 \mathrm{mg}, 0.50 \mu \mathrm{moL}$, $0.10 \mathrm{~mol} \%, 160 \mu \mathrm{L}, 3.13 \mu \mathrm{moL} / \mathrm{mL}$ in THF:DCM (94:6)) and pinacolborane (64.0 $\mathrm{mg}, 73 \mu \mathrm{L}$, $0.50 \mathrm{mmol}, 1.00$ equiv.).

The recorded data is in accordance with the literature. ${ }^{[4]}$

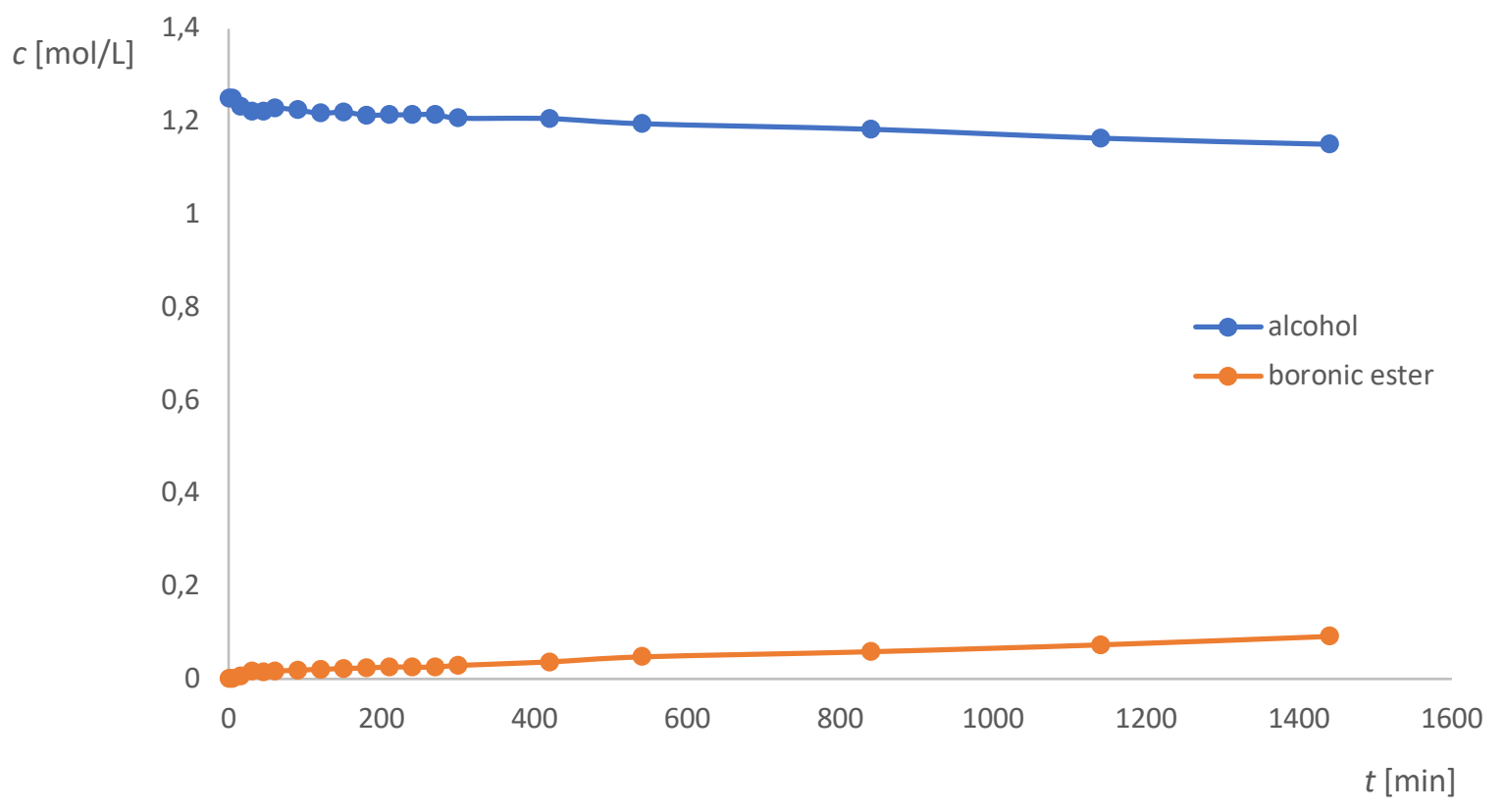

Figure S8: $\quad$ Reaction progress of the esterification of 2 with the addition of TBAI as Iodide source.

By adding TBAI as iodide source, $7 \%$ of $\mathbf{2 B P i n}$ was formed after a reaction time of $24 \mathrm{~h}$. There seems to be no significant accelerating effect with the addition of iodide ions. 
Table S4: Calculated concentration data for $\mathbf{2}$ and 2BPin for the reaction progress with the addition of TBAI as iodide source.

\begin{tabular}{ccc}
\hline$t[\mathrm{~min}]$ & $c(\mathbf{2})[\mathrm{mol} / \mathrm{L}]$ & $c($ 2BPin $)[\mathrm{mol} / \mathrm{L}]$ \\
\hline 0 & 1.25 & 0 \\
15 & 1.23 & 0.01 \\
30 & 1.22 & 0.02 \\
45 & 1.22 & 0.02 \\
60 & 1.23 & 0.02 \\
90 & 1.23 & 0.02 \\
120 & 1.22 & 0.02 \\
150 & 1.22 & 0.02 \\
180 & 1.21 & 0.02 \\
210 & 1.21 & 0.03 \\
240 & 1.22 & 0.03 \\
270 & 1.22 & 0.03 \\
300 & 1.21 & 0.03 \\
420 & 1.21 & 0.04 \\
540 & 1.20 & 0.05 \\
840 & 1.18 & 0.06 \\
1140 & 1.16 & 0.07 \\
1440 & 1.15 & 0.09 \\
\hline
\end{tabular}




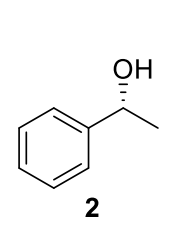

$c=1.25 \mathrm{~mol} / \mathrm{L}$
C1-CI $(0.10 \mathrm{~mol} \%)$

HBPin (1.00 equiv.),

$\stackrel{\text { THF:DCM }(94: 6) / T H F-d 8(3: 2), 25^{\circ} \mathrm{C}}{\longrightarrow}$

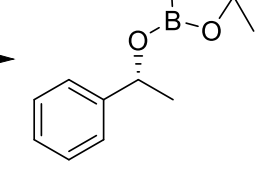

2BPin

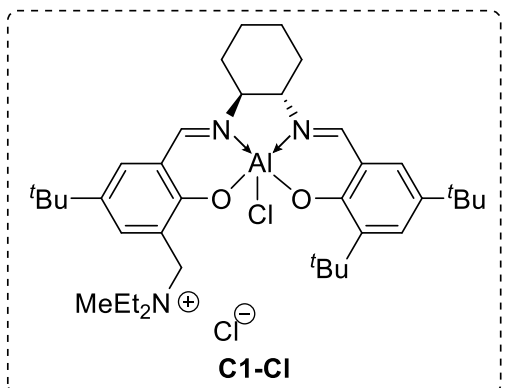

The continuous reaction monitoring was performed according to GP4 using ( $R$ )-1-phenylethanol 2 (61.1 mg, $60 \mu \mathrm{L}, 0.50 \mathrm{mmol}, 1.00$ equiv.), catalyst C1-Cl $(0.34 \mu \mathrm{g}, 0.50 \mu \mathrm{moL}, 0.10 \mathrm{~mol} \%, 120 \mu \mathrm{L}$, $4.17 \mu \mathrm{moL} / \mathrm{mL}$ in THF), dry THF $(30 \mu \mathrm{L})$, dry DCM $(10 \mu \mathrm{L})$ and pinacolborane $(64.0 \mathrm{mg}, 73 \mu \mathrm{L}$, $0.50 \mathrm{mmol}, 1.00$ equiv.).

The recorded data is in accordance with the literature. ${ }^{[4]}$

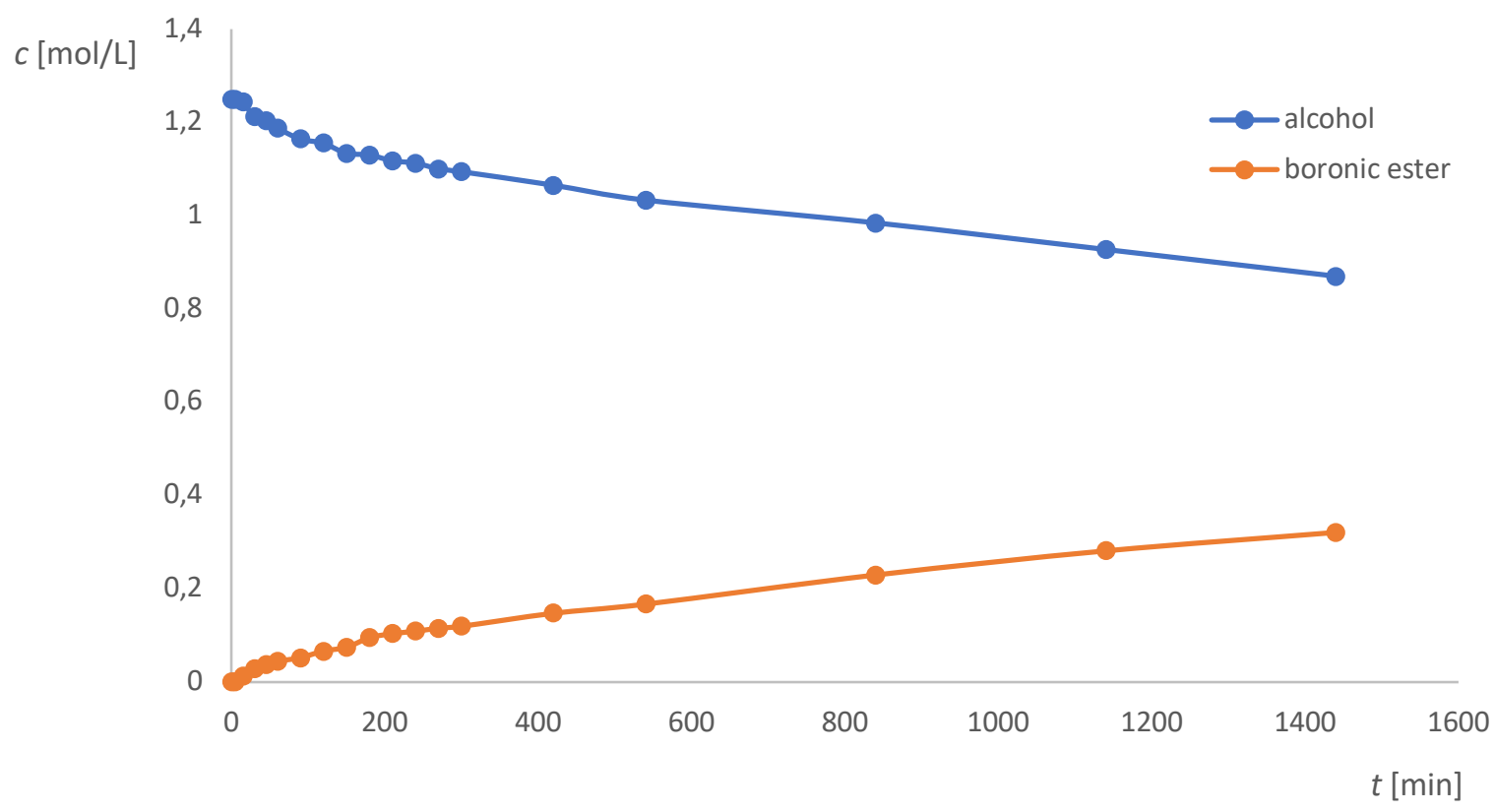

Figure S9: $\quad$ Reaction progress of the esterification of $\mathbf{2}$ with the addition of C1-Cl as halide source.

By adding C1-Cl as halide source, 26\% of 2BPin was formed after a reaction time of $24 \mathrm{~h}$. 
Table S5: Calculated concentration data for $\mathbf{2}$ and 2BPin for the reaction progress with the addition of $\mathbf{C 1 - C l}$ as halide source.

\begin{tabular}{ccc}
\hline$t[\mathrm{~min}]$ & $c(\mathbf{2})[\mathrm{mol} / \mathrm{L}]$ & $c(\mathbf{2 a B P i n})[\mathrm{mol} / \mathrm{L}]$ \\
\hline 0 & 1.25 & 0 \\
15 & 1.24 & 0.01 \\
30 & 1.21 & 0.03 \\
45 & 1.20 & 0.04 \\
60 & 1.19 & 0.04 \\
90 & 1.16 & 0.05 \\
120 & 1.15 & 0.07 \\
150 & 1.13 & 0.07 \\
180 & 1.13 & 0.10 \\
210 & 1.12 & 0.10 \\
240 & 1.11 & 0.11 \\
270 & 1.10 & 0.12 \\
300 & 1.09 & 0.12 \\
420 & 1.07 & 0.15 \\
540 & 1.03 & 0.17 \\
840 & 0.98 & 0.22 \\
1140 & 0.93 & 0.28 \\
1440 & 0.87 & 0.32 \\
\hline
\end{tabular}




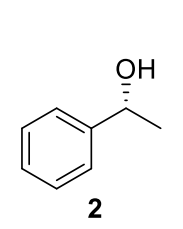

$c=1.25 \mathrm{~mol} / \mathrm{L}$
C1 $(0.10 \mathrm{~mol} \%)$

HBPin (1.00 equiv.),

$\stackrel{\text { THF:DCM }(94: 6) / T H F-d 8(3: 2), 25^{\circ} \mathrm{C}}{\longrightarrow}$

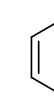

2BPin

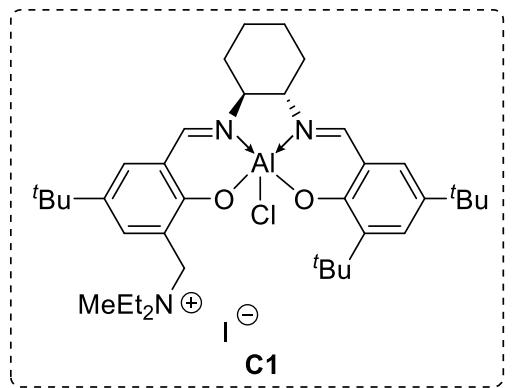

The continuous reaction monitoring was performed according to GP4 using ( $R$ )-1-phenylethanol 2 (61.1 mg, $60 \mu \mathrm{L}, 0.50 \mathrm{mmol}, 1.00$ equiv.), catalyst $\mathbf{C 1}(0.38 \mu \mathrm{g}, 0.50 \mu \mathrm{moL}, 0.10 \mathrm{~mol} \%, 120 \mu \mathrm{L}$, $4.17 \mu \mathrm{moL} / \mathrm{mL}$ in THF), dry THF $(30 \mu \mathrm{L})$, dry DCM $(10 \mu \mathrm{L})$ and pinacolborane $(64.0 \mathrm{mg}, 73 \mu \mathrm{L}$, 0.50 mmol, 1.00 equiv.).

The recorded analytical data is in accordance with the literature. ${ }^{[4]}$

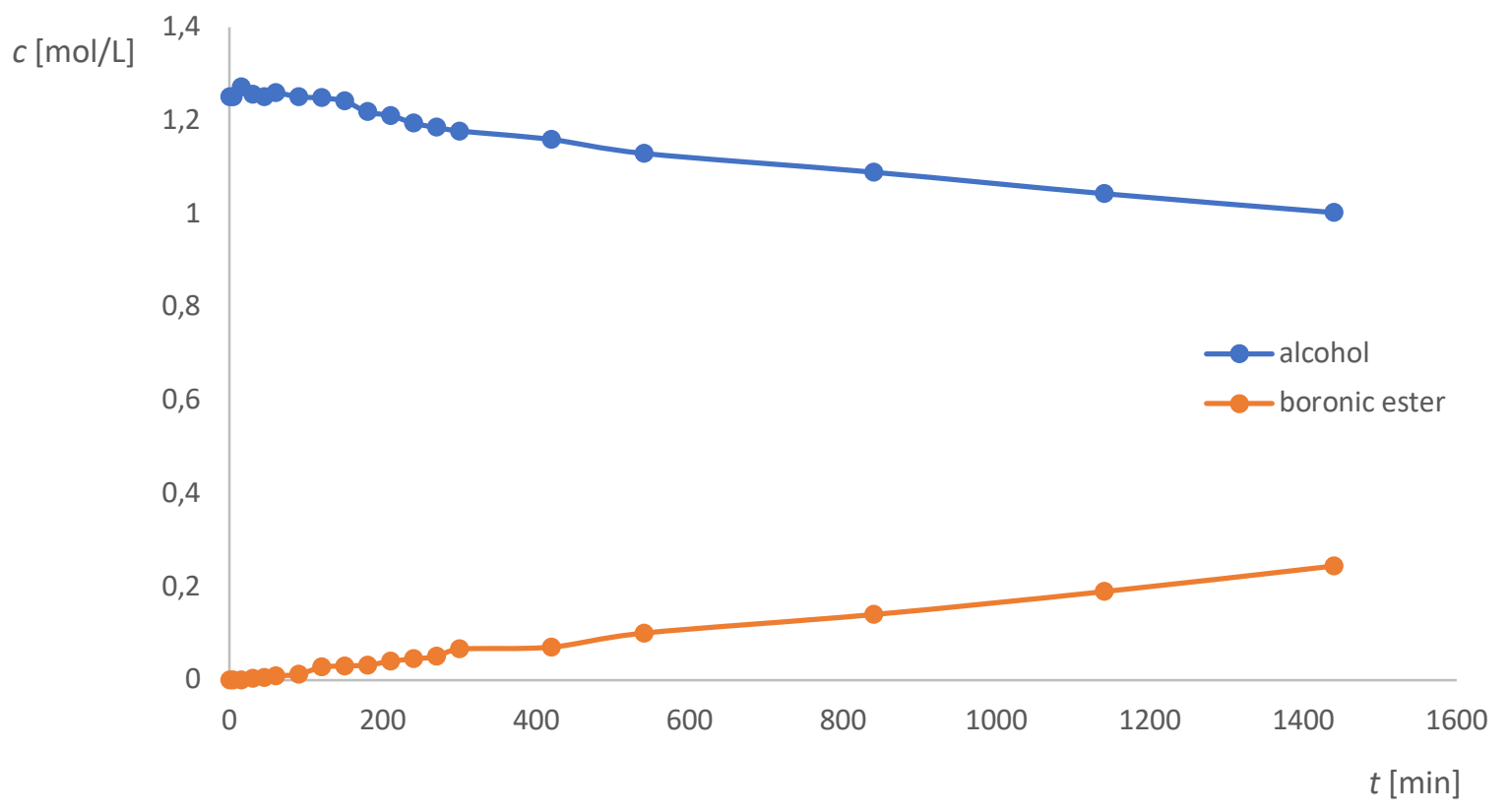

Figure S10: $\quad$ Reaction progress of the esterification of $\mathbf{2}$ with the addition of $\mathbf{C} 1$ as halide source.

By adding $\mathbf{C 1}$ as halide source, $20 \%$ of $\mathbf{2 B P i n}$ was formed after a reaction time of $24 \mathrm{~h}$. With the catalyst C1 the esterification is slower compared to the use of catalyst C1-CI (compare fig. S9-S10 and table S5-S6). 
Table S6: Calculated concentration data for $\mathbf{2}$ and 2BPin for the reaction progress with the addition of $\mathbf{C} 1$ as halide source.

\begin{tabular}{ccc}
\hline$t[\mathrm{~min}]$ & $c(\mathbf{2})[\mathrm{mol} / \mathrm{L}]$ & $c($ 2BPin $)[\mathrm{mol} / \mathrm{L}]$ \\
\hline 0 & 1.25 & 0 \\
15 & 1.27 & 0 \\
30 & 1.26 & 0 \\
45 & 1.25 & 0 \\
60 & 1.26 & 0.01 \\
90 & 1.25 & 0.01 \\
120 & 1.25 & 0.03 \\
150 & 1.24 & 0.03 \\
180 & 1.22 & 0.03 \\
210 & 1.21 & 0.04 \\
240 & 1.19 & 0.05 \\
270 & 1.18 & 0.05 \\
300 & 1.17 & 0.07 \\
420 & 1.16 & 0.07 \\
540 & 1.13 & 0.10 \\
840 & 1.09 & 0.14 \\
1140 & 1.04 & 0.19 \\
1440 & 1.00 & 0.24 \\
\hline
\end{tabular}




\section{Continuous Reaction Monitoring of the Esterification of Pinacolborane with Isopropanol by ${ }^{1} \mathrm{H}-\mathrm{NMR}$ Spectroscopy}

Reaction Monitoring in the Absence of a Halide Source
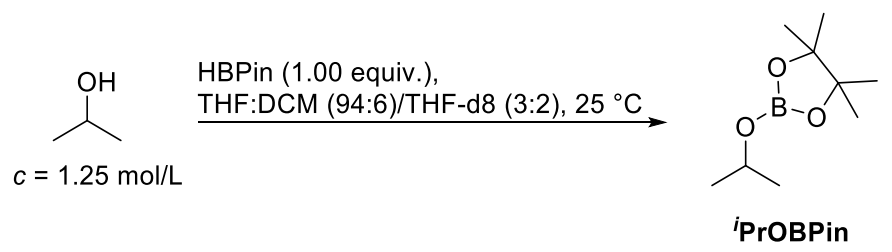

The continuous reaction monitoring was performed according to GP2 using isopropanol (30.1 mg, $38 \mu \mathrm{L}, 0.50 \mathrm{mmol}, 1.00$ equiv.), dry THF:DCM (94:6, $174 \mu \mathrm{L})$ and pinacolborane (64.0 $\mathrm{mg}, 73 \mu \mathrm{L}$, $0.50 \mathrm{mmol}, 1.00$ equiv.).

The recorded data is in accordance with the literature. ${ }^{[5]}$

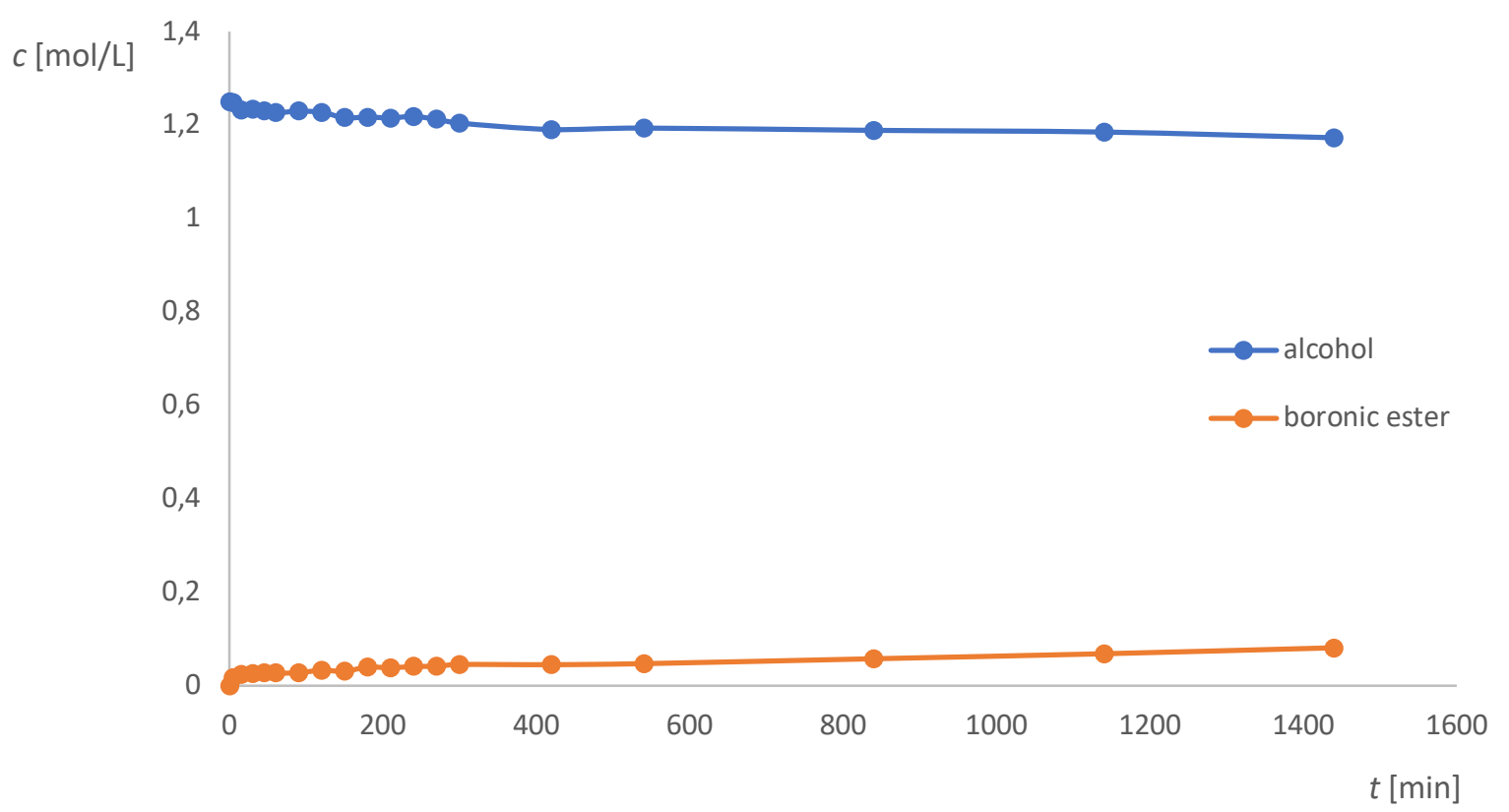

Figure S11: $\quad$ Reaction progress of the esterification of ${ }^{i} \mathrm{PrOH}$ in the absence of a halide source.

In the absence of halides, only $6 \%$ of ${ }^{i}$ PrOBPin was formed after a reaction time of $24 \mathrm{~h}$. 
Table S7: Calculated concentration data for ${ }^{i} \mathrm{PrOH}$ and ${ }^{i} \mathrm{PrOBPin}$ for the reaction progress in the absence of a halide source.

\begin{tabular}{ccc}
\hline$t[\mathrm{~min}]$ & $c\left({ }^{i} \mathrm{PrOH}\right)[\mathrm{mol} / \mathrm{L}]$ & $c($ PrOBPin $)[\mathrm{mol} / \mathrm{L}]$ \\
\hline 0 & 1.25 & 0 \\
15 & 1.23 & 0.02 \\
30 & 1.23 & 0.03 \\
45 & 1.23 & 0.03 \\
60 & 1.23 & 0.03 \\
90 & 1.23 & 0.03 \\
120 & 1.23 & 0.03 \\
150 & 1.22 & 0.03 \\
180 & 1.22 & 0.04 \\
210 & 1.22 & 0.04 \\
240 & 1.22 & 0.04 \\
270 & 1.21 & 0.04 \\
300 & 1.20 & 0.05 \\
420 & 1.19 & 0.05 \\
540 & 1.19 & 0.05 \\
840 & 1.19 & 0.06 \\
1140 & 1.18 & 0.07 \\
1440 & 1.17 & 0.08 \\
\hline
\end{tabular}




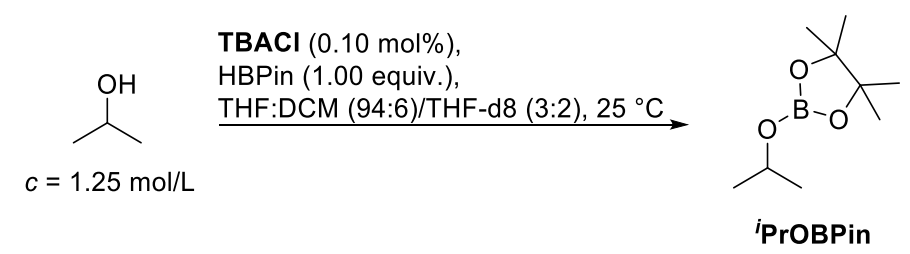

The continuous reaction monitoring was performed according to GP3 using isopropanol (30.1 mg, $38 \mu \mathrm{L}, 0.50 \mathrm{mmol}, 1.00$ equiv. $)$, freshly prepared TBACl stock solution $(0.14 \mathrm{mg}, 0.50 \mu \mathrm{moL}$, $0.10 \mathrm{~mol} \%, 160 \mu \mathrm{L}, 3.13 \mu \mathrm{moL} / \mathrm{mL}$ in THF:DCM (94:6)), dry THF:DCM (94:6, $14 \mu \mathrm{L}$ ) and pinacolborane (64.0 mg, $73 \mu \mathrm{L}, 0.50 \mathrm{mmol}, 1.00$ equiv.).

The recorded analytical data is in accordance with the literature. ${ }^{[5]}$

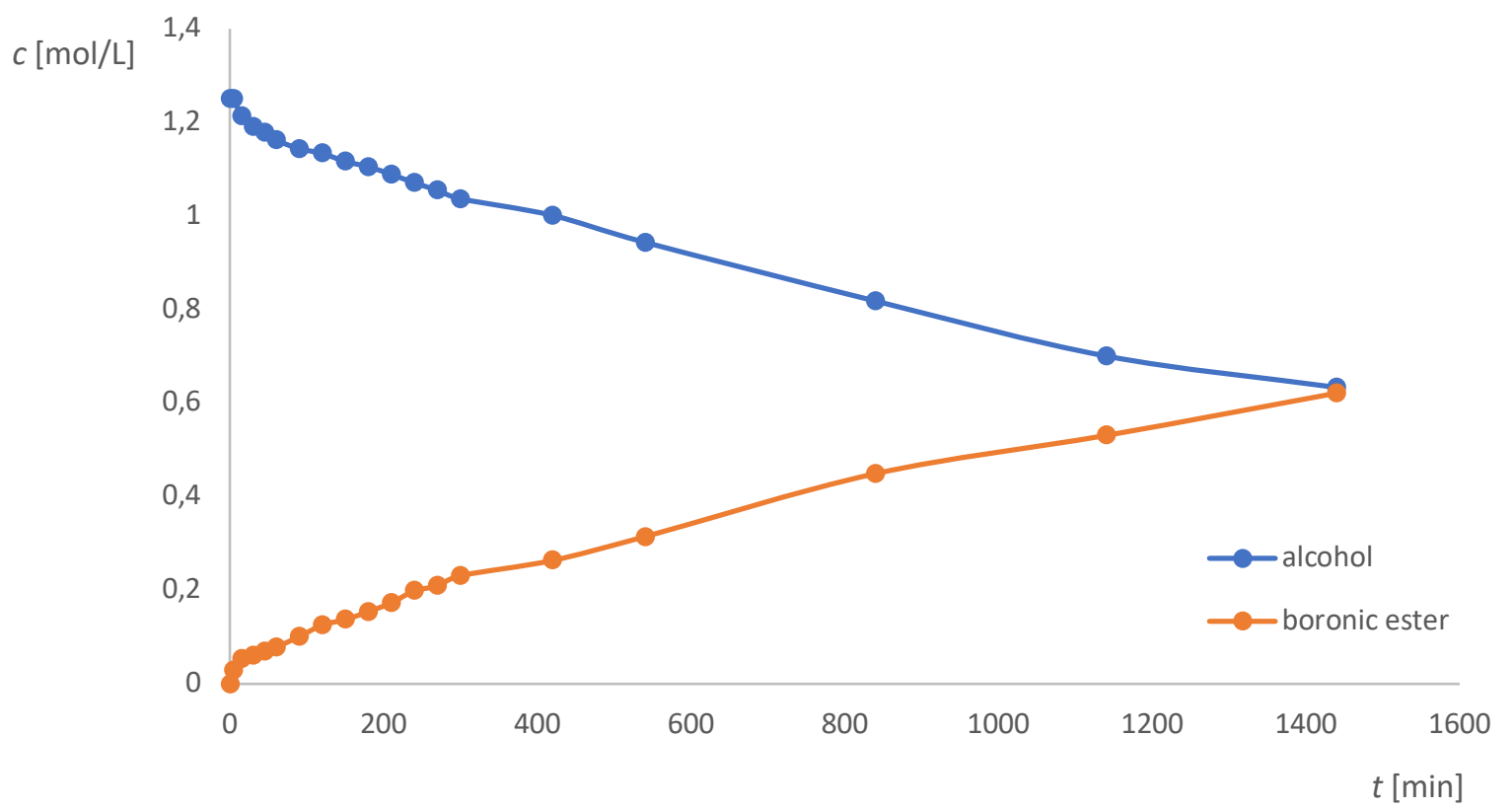

Figure S12: Reaction progress of the esterification of ${ }^{i} \mathrm{PrOH}$ with the addition of $\mathbf{T B A C l}$ as Chloride source.

By adding TBACl as chloride source, 50\% of ${ }^{i}$ PrOBPin was formed after a reaction time of $24 \mathrm{~h}$. The accelerating effect of a catalytical amount of chloride ions on the esterification can also be observed here. 
Table S8: Calculated concentration data for ${ }^{i} \mathrm{PrOH}$ and ${ }^{i} \mathrm{PrOBPin}$ for the reaction progress with the addition of TBACI as chloride source.

\begin{tabular}{ccc}
\hline$t[\mathrm{~min}]$ & $c\left({ }^{i} \mathrm{PrOH}\right)[\mathrm{mol} / \mathrm{L}]$ & $c\left({ }^{i}\right.$ PrOBPin $)[\mathrm{mol} / \mathrm{L}]$ \\
\hline 0 & 1.25 & 0 \\
15 & 1.21 & 0.05 \\
30 & 1.19 & 0.06 \\
45 & 1.18 & 0.07 \\
60 & 1.16 & 0.08 \\
90 & 1.14 & 0.10 \\
120 & 1.13 & 0.13 \\
150 & 1.11 & 0.14 \\
180 & 1.11 & 0.15 \\
210 & 1.08 & 0.17 \\
240 & 1.07 & 0.20 \\
270 & 1.05 & 0.21 \\
300 & 1.04 & 0.23 \\
420 & 1.00 & 0.23 \\
540 & 0.94 & 0.31 \\
840 & 0.82 & 0.45 \\
1140 & 0.70 & 0.53 \\
1440 & 0.63 & 0.62 \\
\hline
\end{tabular}


Reaction Monitoring with the Addition of TBAl as lodide Source

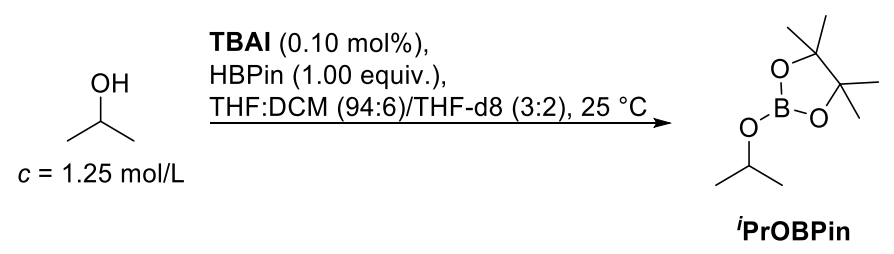

The continuous reaction monitoring was performed according to GP3 using isopropanol (30.1 mg, $38 \mu \mathrm{L}, 0.50 \mathrm{mmol}, 1.00$ equiv.), freshly prepared TBAI stock solution $(0.18 \mathrm{mg}, 0.50 \mu \mathrm{moL}$, $0.10 \mathrm{~mol} \%, \quad 160 \mu \mathrm{L}, 3.13 \mu \mathrm{moL} / \mathrm{mL}$ in THF:DCM (94:6)), dry THF:DCM (94:6, $14 \mu \mathrm{L}$ ) and pinacolborane (64.0 mg, $73 \mu \mathrm{L}, 0.50 \mathrm{mmol}, 1.00$ equiv.).

The analytical data is in accordance with the literature. ${ }^{[5]}$

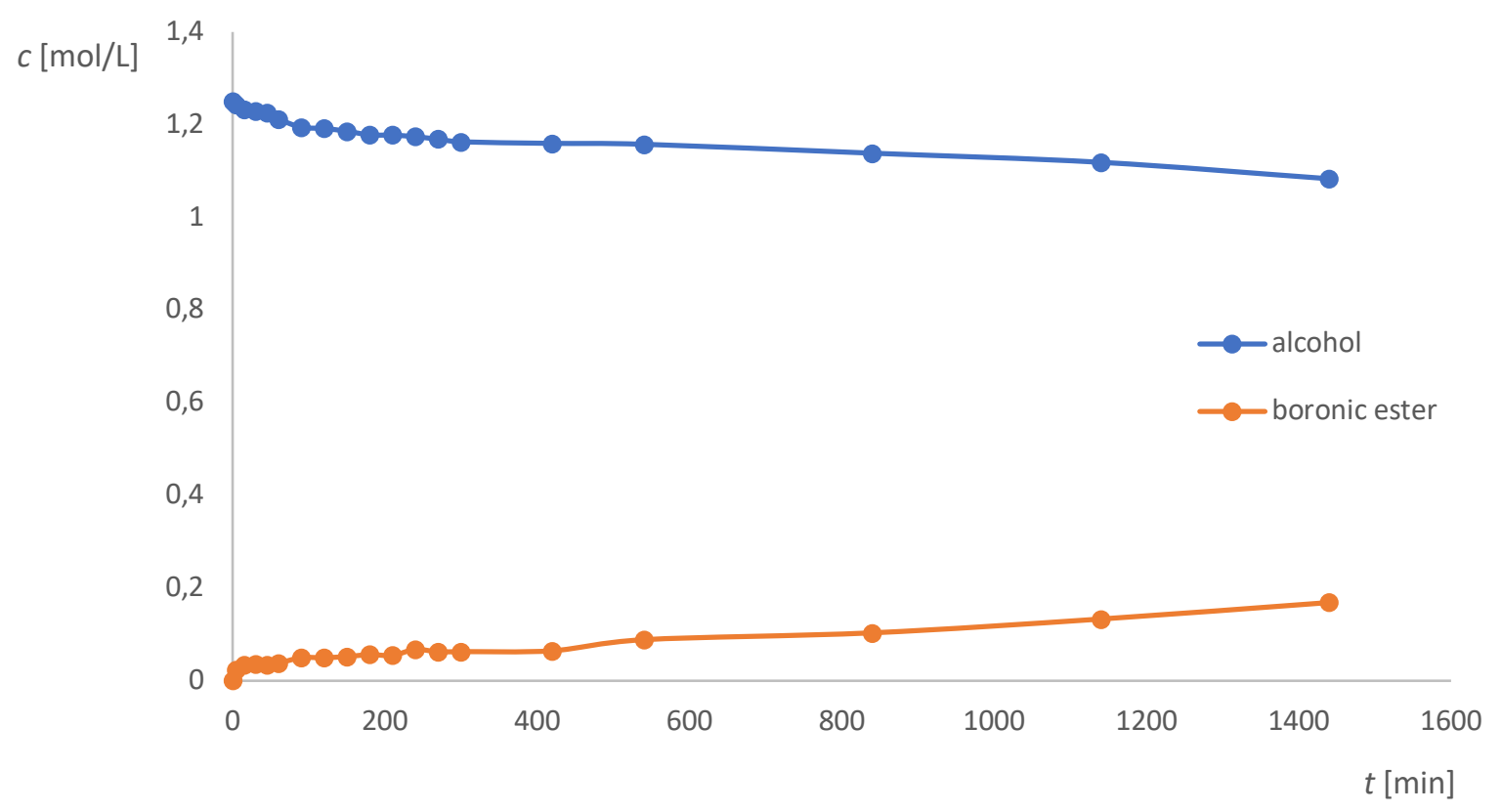

Figure S13: $\quad$ Reaction progress of the esterification of ${ }^{i} \mathrm{PrOH}$ with the addition of TBAI as iodide source.

By adding TBAI as iodide source, $14 \%$ of ${ }^{i}$ PrOBPin was formed after a reaction time of $24 \mathrm{~h}$. 
Table S9: Calculated concentration data for ${ }^{i} \mathrm{PrOH}$ and ${ }^{i} \mathrm{PrOBPin}$ for the reaction progress with the addition of TBAI as iodide source.

\begin{tabular}{ccc}
\hline$t[\mathrm{~min}]$ & $c\left({ }^{i} \mathrm{PrOH}\right)[\mathrm{mol} / \mathrm{L}]$ & $c\left({ }^{i}\right.$ PrOBPin $)[\mathrm{mol} / \mathrm{L}]$ \\
\hline 0 & 1.25 & 0 \\
15 & 1.23 & 0.03 \\
30 & 1.23 & 0.04 \\
45 & 1.23 & 0.03 \\
60 & 1.21 & 0.04 \\
90 & 1.19 & 0.05 \\
120 & 1.19 & 0.05 \\
150 & 1.19 & 0.05 \\
180 & 1.18 & 0.06 \\
210 & 1.18 & 0.05 \\
240 & 1.17 & 0.07 \\
270 & 1.17 & 0.06 \\
300 & 1.16 & 0.06 \\
420 & 1.16 & 0.06 \\
540 & 1.16 & 0.09 \\
840 & 1.14 & 0.10 \\
1140 & 1.12 & 0.13 \\
1440 & 1.08 & 0.17 \\
\hline
\end{tabular}



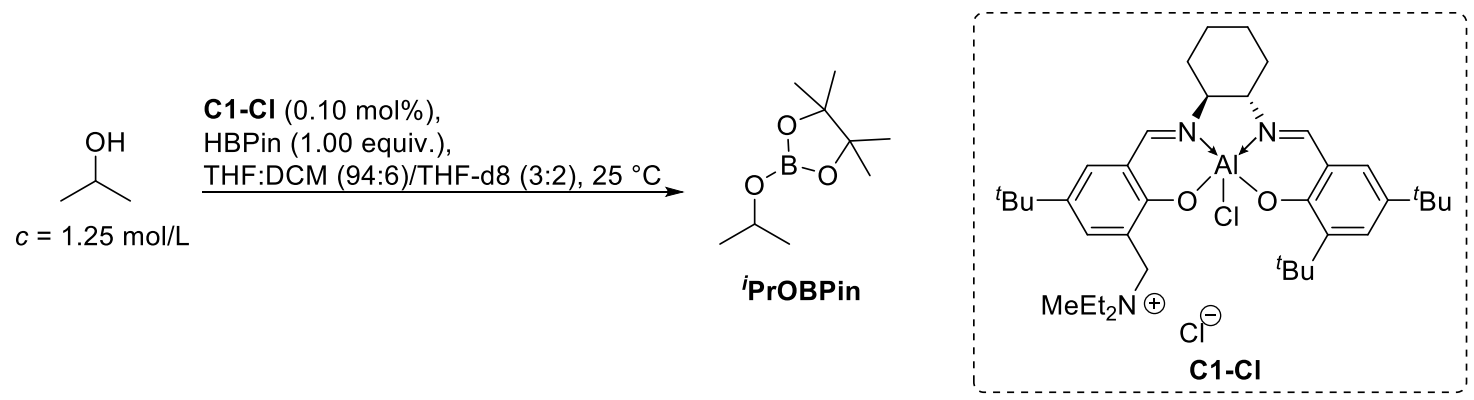

The continuous reaction monitoring was performed according to GP4 using isopropanol (30.1 mg, $38 \mu \mathrm{L}, \quad 0.50 \mathrm{mmol}, 1.00$ equiv. $)$ catalyst C1-Cl $(0.34 \mu \mathrm{g}, 0.50 \mu \mathrm{moL}, 0.10 \mathrm{~mol} \%, 120 \mu \mathrm{L}$, $4.17 \mu \mathrm{moL} / \mathrm{mL}$ in THF), dry THF $(44 \mu \mathrm{L})$, dry DCM $(10 \mu \mathrm{L})$ and pinacolborane $(64.0 \mathrm{mg}, 73 \mu \mathrm{L}$, $0.50 \mathrm{mmol}, 1.00$ equiv.).

The recorded data is in accordance with the literature. ${ }^{[5]}$

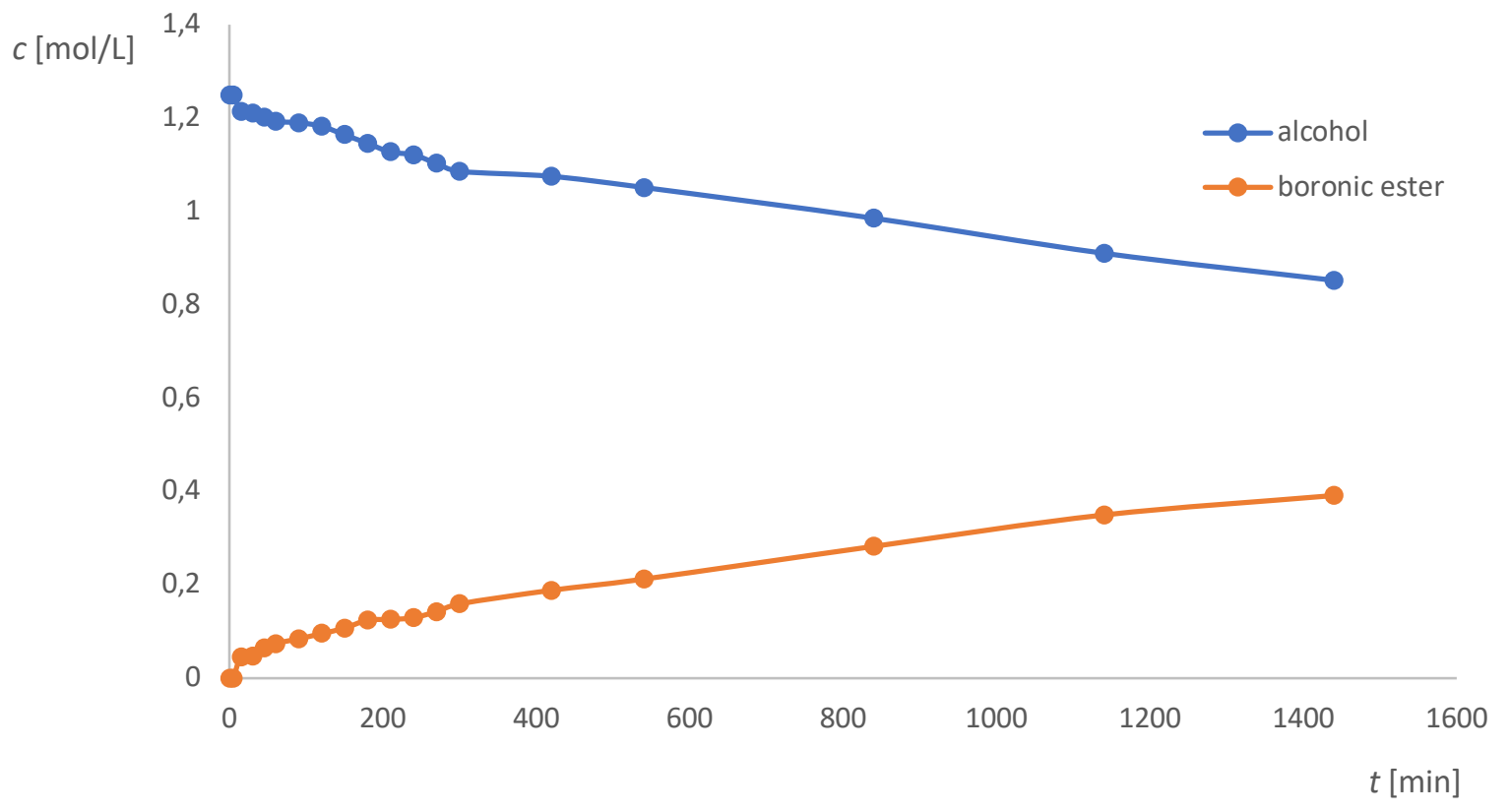

Figure S14: Reaction progress of the esterification of ${ }^{i} \mathrm{PrOH}$ with the addition of $\mathbf{C 1}-\mathbf{C l}$ as halide source.

By adding C1-Cl as halide source, $31 \%$ of ${ }^{i}$ PrOBPin was formed after a reaction time of $24 \mathrm{~h}$. 
Table S10: $\quad$ Calculated concentration data for ${ }^{i} \mathrm{PrOH}$ and ${ }^{i} \mathrm{PrOBPin}$ for the reaction progress with the addition of $\mathbf{C 1 - C l}$ as halide source.

\begin{tabular}{ccc}
\hline$t[\mathrm{~min}]$ & $c\left({ }^{i} \mathrm{PrOH}\right)[\mathrm{mol} / \mathrm{L}]$ & $c\left({ }^{i}\right.$ PrOBPin $)[\mathrm{mol} / \mathrm{L}]$ \\
\hline 0 & 1.25 & 0 \\
15 & 1.21 & 0.05 \\
30 & 1.21 & 0.05 \\
45 & 1.20 & 0.06 \\
60 & 1.19 & 0.07 \\
90 & 1.19 & 0.08 \\
120 & 1.18 & 0.10 \\
150 & 1.16 & 0.10 \\
180 & 1.15 & 0.12 \\
210 & 1.13 & 0.13 \\
240 & 1.12 & 0.13 \\
270 & 1.10 & 0.14 \\
300 & 1.09 & 0.16 \\
420 & 1.08 & 0.19 \\
540 & 1.05 & 0.21 \\
840 & 0.98 & 0.28 \\
1140 & 0.91 & 0.35 \\
1440 & 0.85 & 0.39 \\
\hline
\end{tabular}



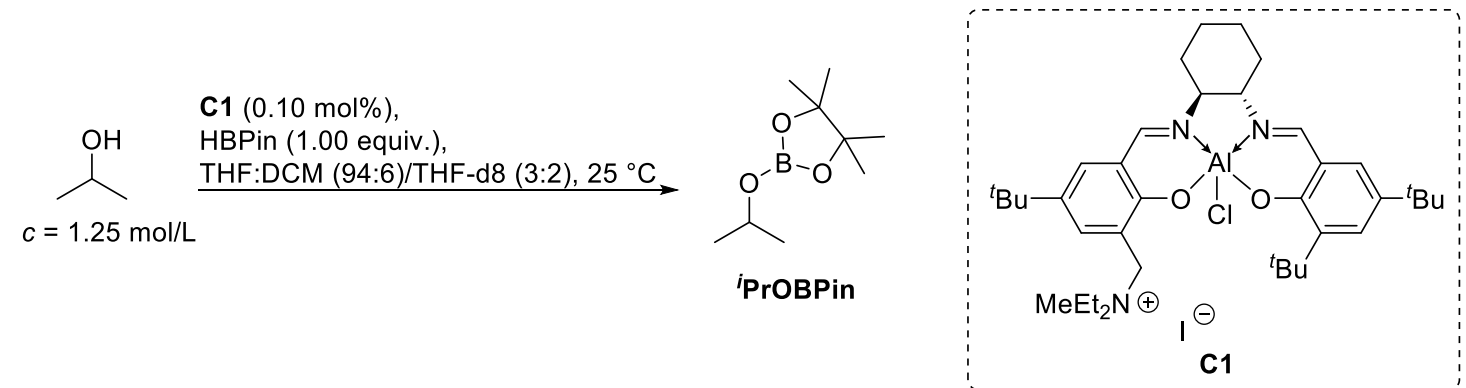

The continuous reaction monitoring was performed according to GP4 using isopropanol (30.1 mg, $38 \mu \mathrm{L}, 0.50 \mathrm{mmol}, 1.00$ equiv.), catalyst $\mathbf{C 1}(0.38 \mu \mathrm{g}, 0.50 \mu \mathrm{moL}, 0.10 \mathrm{~mol} \%, 120 \mu \mathrm{L}, 4.17 \mu \mathrm{moL} / \mathrm{mL}$ in THF), dry THF $(44 \mu \mathrm{L})$, dry DCM $(10 \mu \mathrm{L})$ and pinacolborane $(64.0 \mathrm{mg}, 73 \mu \mathrm{L}, 0.50 \mathrm{mmol}$, 1.00 equiv.).

The recorded data is in accordance with the literature. ${ }^{[5]}$

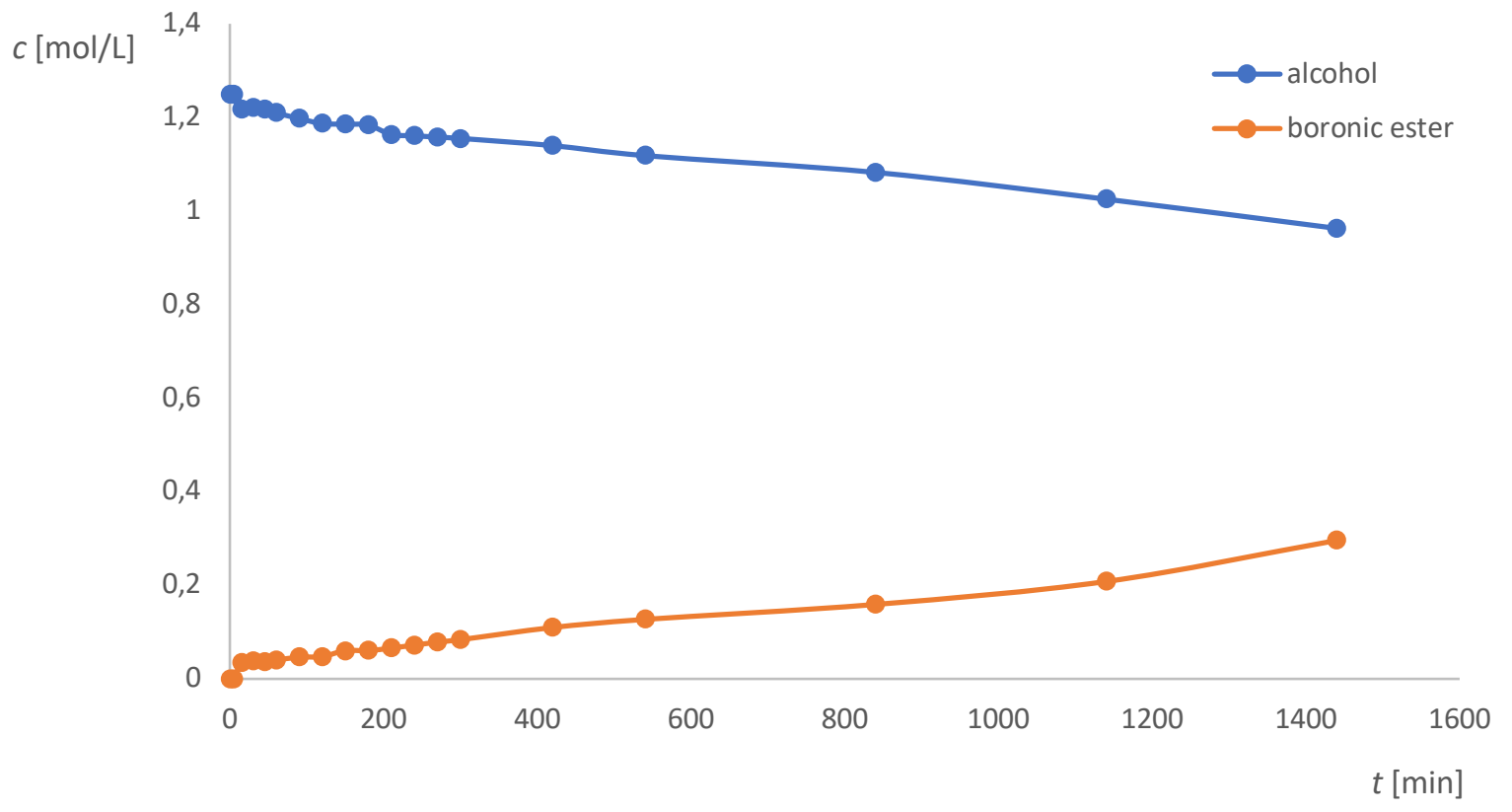

Figure S15: $\quad$ Reaction progress of the esterification of ${ }^{i} \mathrm{PrOH}$ with the addition of $\mathbf{C 1}$ as halide source.

By adding $\mathbf{C 1}$ as halide source, $24 \%$ of ${ }^{i}$ PrOBPin was formed after a reaction time of $24 \mathrm{~h}$. The reaction proceeds slower with the use of catalyst $\mathbf{C 1}$ compared to the use of $\mathbf{C 1 - C l}$ as halide source (compare fig. S14-S15 and table S10-S11). 
Table S11: $\quad$ Calculated concentration data for ${ }^{i} \mathrm{PrOH}$ and ${ }^{i} \mathrm{PrOBPin}$ for the reaction progress with the addition of $\mathbf{C 1}$ as halide source.

\begin{tabular}{|c|c|c|}
\hline$t[\min ]$ & $c\left({ }^{i} \mathrm{PrOH}\right)[\mathrm{mol} / \mathrm{L}]$ & $c\left({ }^{i}\right.$ PrOBPin $)[\mathrm{mol} / \mathrm{L}]$ \\
\hline 0 & 1.25 & 0 \\
\hline 15 & 1.22 & 0.03 \\
\hline 30 & 1.22 & 0.04 \\
\hline 45 & 1.22 & 0.04 \\
\hline 60 & 1.21 & 0.04 \\
\hline 90 & 1.20 & 0.05 \\
\hline 120 & 1.19 & 0.05 \\
\hline 150 & 1.19 & 0.06 \\
\hline 180 & 1.18 & 0.06 \\
\hline 210 & 1.16 & 0.07 \\
\hline 240 & 1.16 & 0.07 \\
\hline 270 & 1.16 & 0.08 \\
\hline 300 & 1.16 & 0.08 \\
\hline 420 & 1.14 & 0.11 \\
\hline 540 & 1.12 & 0.13 \\
\hline 840 & 1.08 & 0.16 \\
\hline 1140 & 1.03 & 0.21 \\
\hline 1440 & 0.96 & 0.30 \\
\hline
\end{tabular}




\section{Continuous Reaction Monitoring of the Asymmetric Reduction of Acetophenone with Pinacolborane and $\mathrm{C} 1-\mathrm{Cl}$ by ${ }^{1} \mathrm{H}-\mathrm{NMR}$ Spectroscopy}
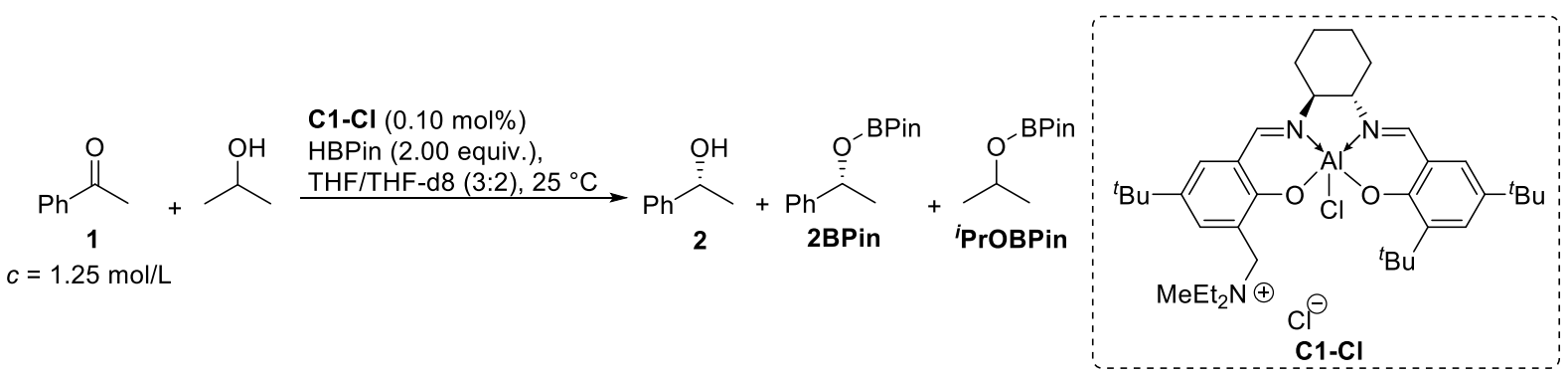

The continuous reaction monitoring followed a literature protocol ${ }^{[2]}$ using acetophenone $1(60.1 \mathrm{mg}$, $58 \mu \mathrm{L}, \quad 0.50 \mathrm{mmol}, \quad 1.00$ equiv. $)$, catalyst $\mathbf{C 1}-\mathrm{Cl} \quad(0.38 \mu \mathrm{g}, \quad 0.50 \mu \mathrm{moL}, \quad 0.10 \mathrm{~mol} \%, \quad 120 \mu \mathrm{L}$ $4.17 \mu \mathrm{moL} / \mathrm{mL}$ in THF), pinacolborane (128.0 mg, $145 \mu \mathrm{L}, 1.00 \mathrm{mmol}, 2.00$ equiv.) and isopropanol (30.1 mg, $38 \mu \mathrm{L}, 0.50 \mathrm{mmol}, 1.00$ equiv.). All reagents were added directly to a graduated Young-NMR vial. Subsequently, the glass wall was rinsed with dry THF-d8 making it a $1.25 \mathrm{~mol} / \mathrm{L}$ solution in terms of $\mathbf{1}$. The sample was then continuously monitored by ${ }^{1} \mathrm{H}-\mathrm{NMR}$ spectroscopy.

The calculated data was then compared to the monitoring data using catalyst $\mathbf{C 1} .^{[2]}$ In the first $2 \mathrm{~h}$ of the reaction, the catalysts $\mathbf{C 1 - C l}$ or $\mathbf{C 1}$ seem to act almost equally fast. After $2 \mathrm{~h}$ the reaction gets faster using the catalyst $\mathbf{C 1}$ (see fig. S16).

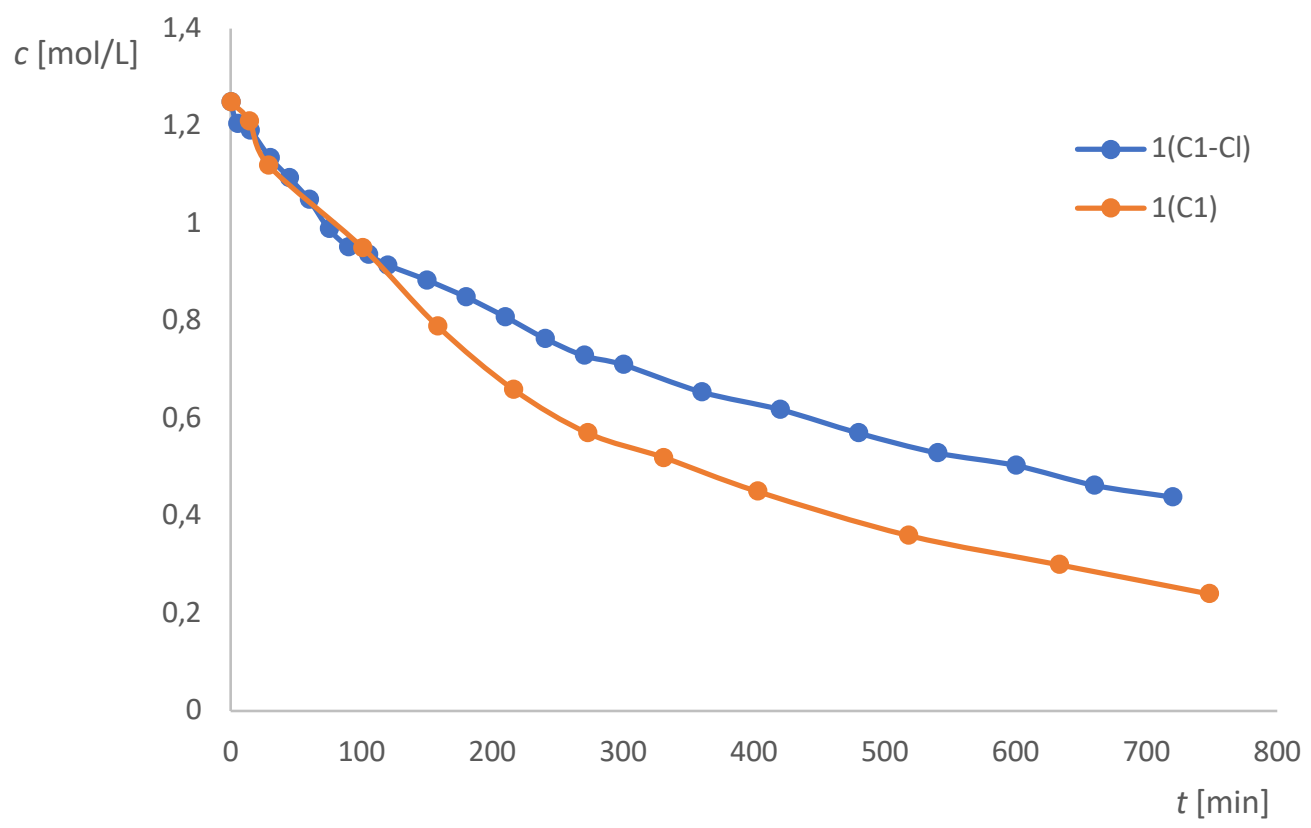

Figure S16: $\quad$ Conversion of 1: comparison of $\mathbf{C 1 - C l}$ and $\mathbf{C 1}$ as catalysts. 
The formation of 2 seems to be equally fast in the first $60 \mathrm{~min}$ of reaction time. After $60 \mathrm{~min}$, the formation of $\mathbf{2}$ proceeds faster using the catalyst $\mathbf{C 1}$ (see fig. S17).

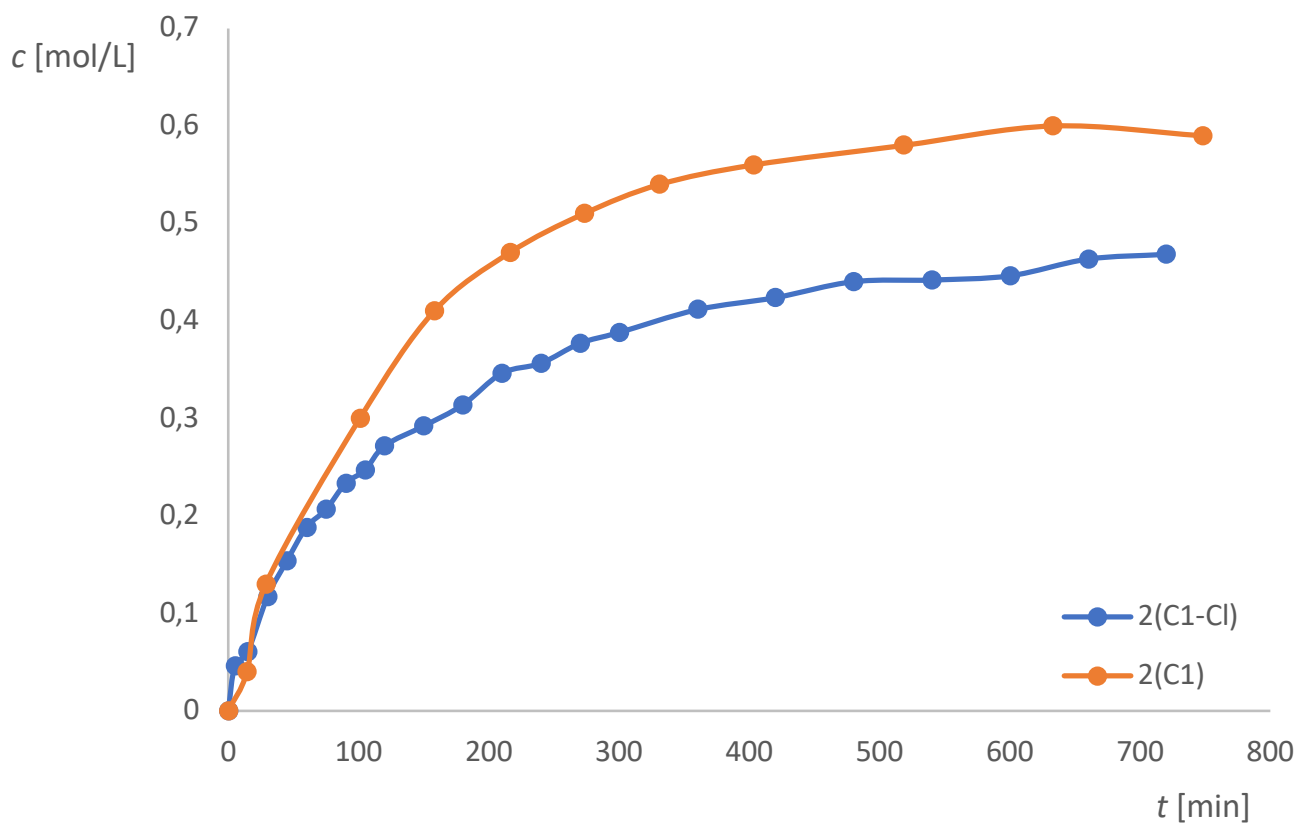

Figure S17: Formation of 2: comparison of $\mathbf{C 1}-\mathbf{C l}$ and $\mathbf{C 1}$ as catalysts.

While the boronic ester 2BPin is formed right from the beginning of the reaction using the catalyst C1-Cl, the formation of 2BPin starts after approx. $1.75 \mathrm{~h}$ using the catalyst C1 (see fig. S18).

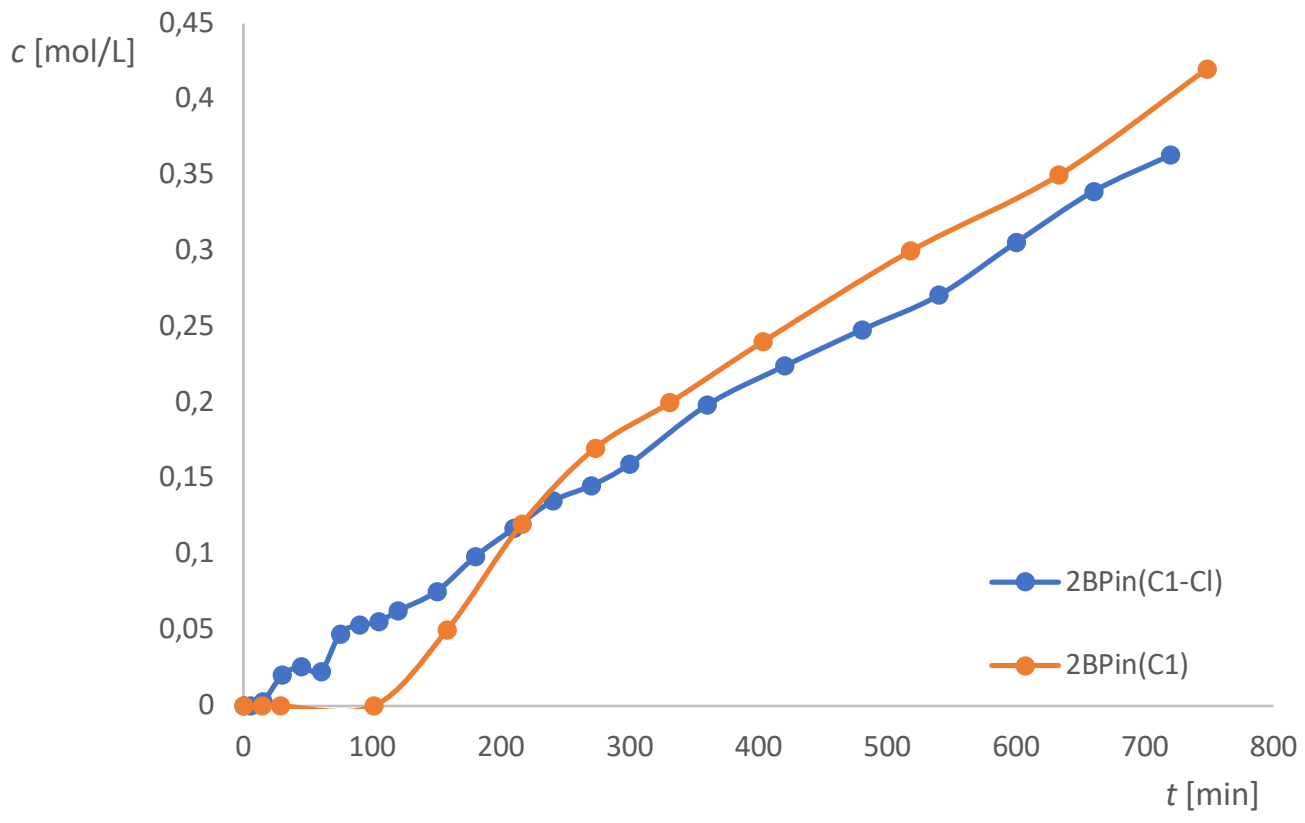

Figure S18: Formation of 2BPin: comparison of $\mathbf{C 1}-\mathbf{C l}$ and $\mathbf{C 1}$ as catalysts. 
Also, the conversion of isopropanol proceeds faster using the catalyst $\mathbf{C 1 - C l}$ compared to $\mathbf{C 1}$ (see fig. S19).

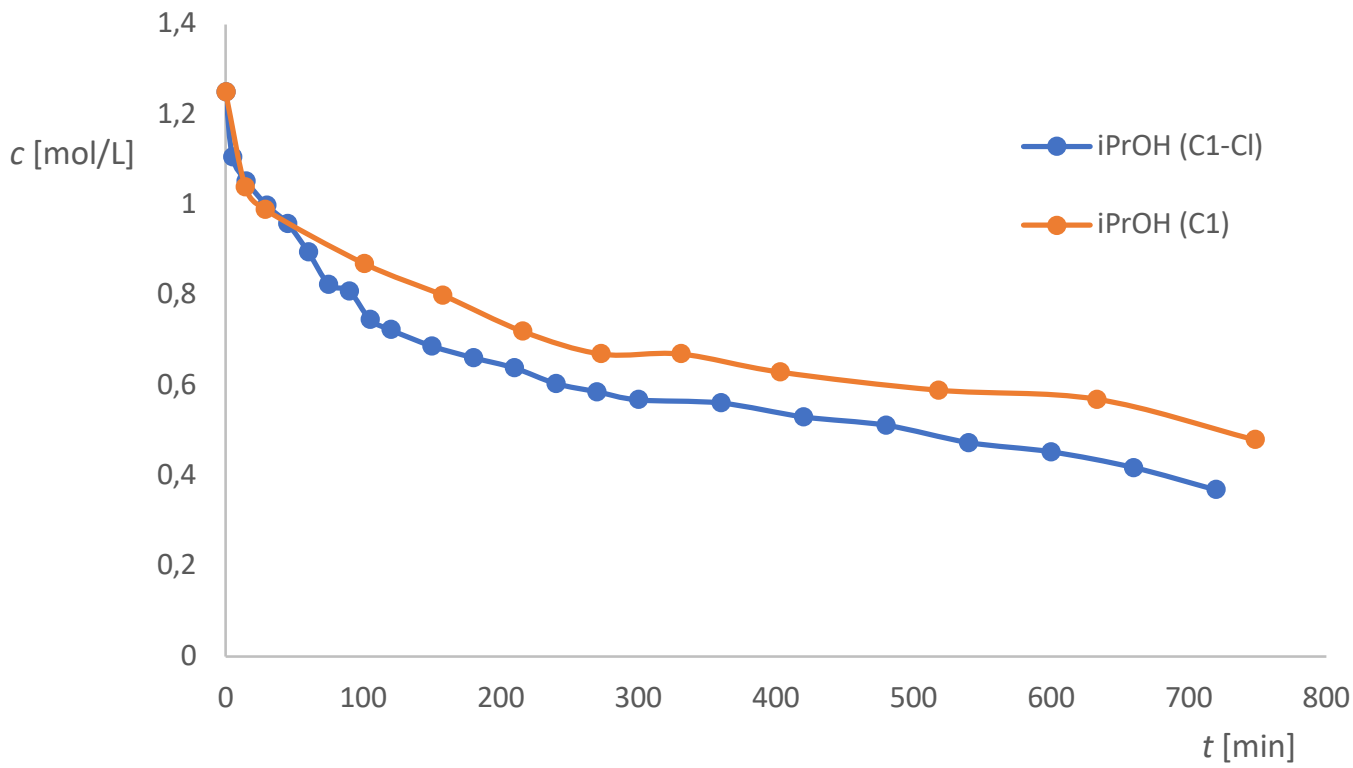

Figure S19: Conversion of ${ }^{i}$ isopropanol: comparison of $\mathbf{C 1 - C l}$ and $\mathbf{C} 1$ as catalysts.

The formation of ${ }^{i}$ PrOBPin proceeds faster using the catalyst C1-Cl (see fig. S20).

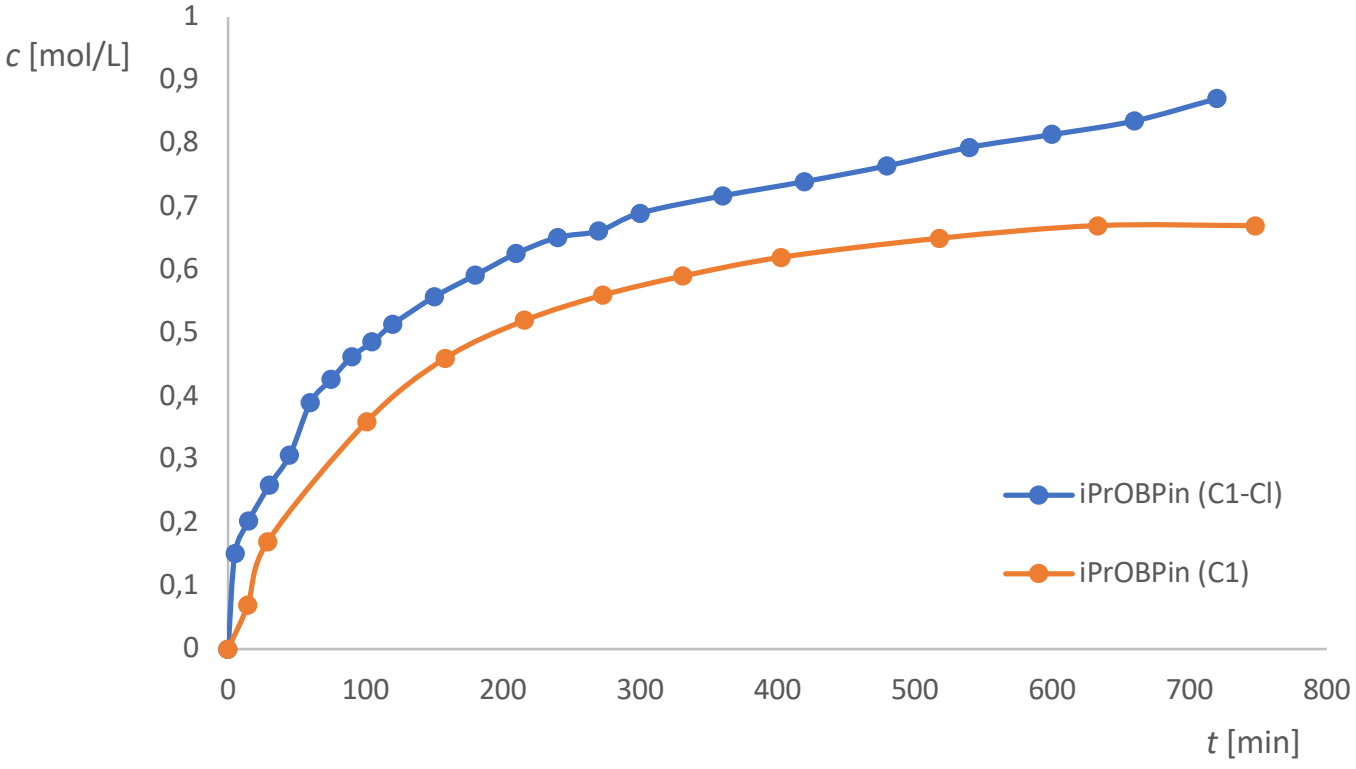

Figure S20: $\quad$ Formation of ${ }^{i}$ PrOBPin: comparison of $\mathbf{C 1 - C l}$ and $\mathbf{C 1}$ as catalysts. 
Also, the conversion of HBPin proceeds faster using the catalyst C1-Cl compared to C1 (see fig. S21).

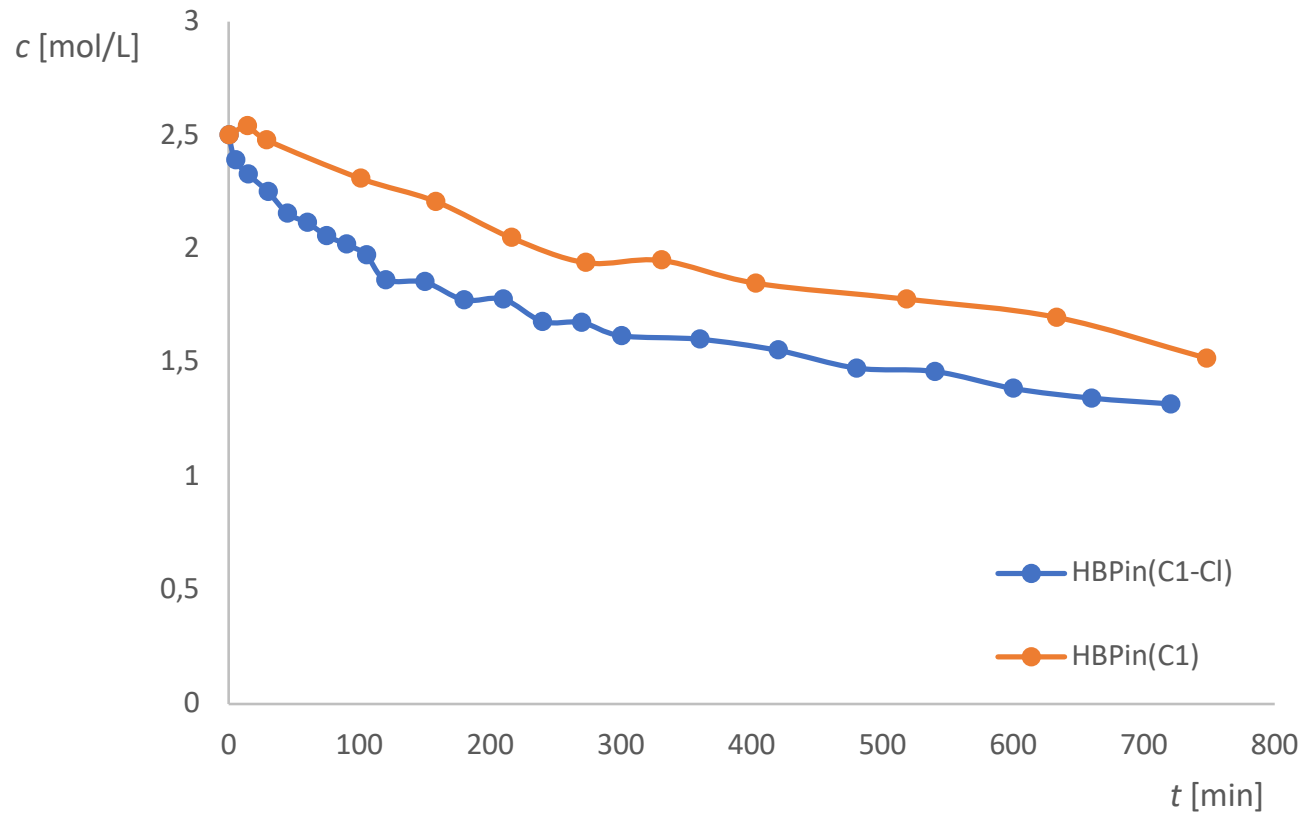

Figure S21: Conversion of HBPin: comparison of $\mathbf{C 1 - C l}$ and $\mathbf{C 1}$ as catalysts. 
Table S12: $\quad$ Calculated concentration data for the reaction progress using $\mathbf{C 1 - C l}$ as catalyst.

\begin{tabular}{|c|c|c|c|c|c|c|}
\hline $\begin{array}{c}t \\
{[\mathrm{~min}]}\end{array}$ & $\begin{array}{c}c(\mathbf{1}) \\
{[\mathrm{mol} / \mathrm{L}]}\end{array}$ & $\begin{array}{c}c(\mathbf{2}) \\
{[\mathrm{mol} / \mathrm{L}]}\end{array}$ & $\begin{array}{c}c \text { (2BPin) } \\
{[\mathrm{mol} / \mathrm{L}]}\end{array}$ & $\begin{array}{c}c\left({ }^{i} \mathrm{PrOH}\right) \\
{[\mathrm{mol} / \mathrm{L}]}\end{array}$ & $\begin{array}{c}c\left({ }^{i} \text { PrOBPin }\right) \\
{[\mathrm{mol} / \mathrm{L}]}\end{array}$ & $\begin{array}{c}c \text { (HBPin) } \\
{[\mathrm{mol} / \mathrm{L}]}\end{array}$ \\
\hline 0 & 1.25 & 0 & 0 & 1.25 & 0 & 2.5 \\
\hline 15 & 1.19 & 0.06 & 0 & 1.05 & 0.20 & 2.33 \\
\hline 30 & 1.14 & 0.12 & 0.02 & 1.00 & 0.26 & 2.25 \\
\hline 45 & 1.09 & 0.15 & 0.03 & 0.96 & 0.31 & 2.16 \\
\hline 60 & 1.05 & 0.19 & 0.02 & 0.90 & 0.39 & 2.12 \\
\hline 75 & 0.99 & 0.21 & 0.05 & 0.82 & 0.43 & 2.06 \\
\hline 90 & 0.95 & 0.23 & 0.05 & 0.81 & 0.46 & 2.02 \\
\hline 105 & 0.94 & 0.25 & 0.06 & 0.75 & 0.49 & 1.98 \\
\hline 120 & 0.91 & 0.27 & 0.06 & 0.72 & 0.51 & 1.86 \\
\hline 150 & 0.88 & 0.29 & 0.08 & 0.69 & 0.56 & 1.85 \\
\hline 180 & 0.85 & 0.31 & 0.10 & 0.66 & 0.59 & 1.78 \\
\hline 210 & 0.81 & 0.35 & 0.12 & 0.64 & 0.63 & 1.78 \\
\hline 240 & 0.76 & 0.36 & 0.14 & 0.60 & 0.65 & 1.68 \\
\hline 270 & 0.73 & 0.38 & 0.15 & 0.59 & 0.66 & 1.68 \\
\hline 300 & 0.71 & 0.39 & 0.16 & 0.57 & 0.69 & 1.62 \\
\hline 360 & 0.65 & 0.41 & 0.20 & 0.56 & 0.72 & 1.60 \\
\hline 420 & 0.62 & 0.42 & 0.22 & 0.53 & 0.74 & 1.55 \\
\hline 480 & 0.57 & 0.44 & 0.25 & 0.51 & 0.76 & 1.48 \\
\hline 540 & 0.53 & 0.44 & 0.27 & 0.47 & 0.79 & 1.46 \\
\hline 600 & 0.50 & 0.45 & 0.31 & 0.45 & 0.81 & 1.39 \\
\hline 660 & 0.46 & 0.46 & 0.34 & 0.42 & 0.84 & 1.34 \\
\hline 720 & 0.44 & 0.47 & 0.36 & 0.37 & 0.87 & 1.32 \\
\hline
\end{tabular}



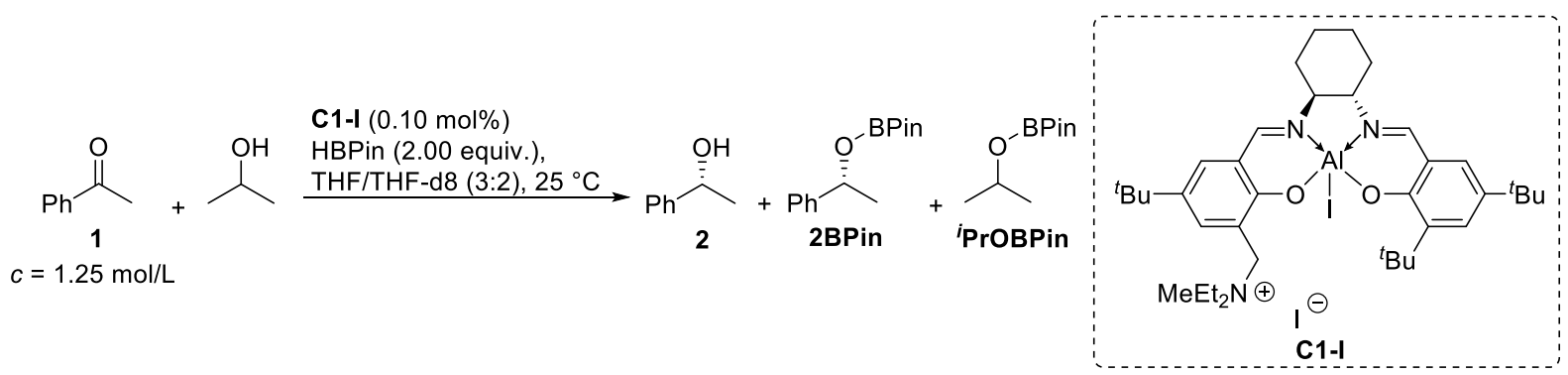

The continuous reaction monitoring followed a literature protocol ${ }^{[2]}$ using acetophenone $1(60.1 \mathrm{mg}$, $58 \mu \mathrm{L}, 0.50 \mathrm{mmol}, 1.00$ equiv. $)$, catalyst C1-I ( $0.43 \mu \mathrm{g}, 0.50 \mu \mathrm{moL}, 0.10 \mathrm{~mol} \%, 120 \mu \mathrm{L} 4.17 \mu \mathrm{moL} / \mathrm{mL}$ in THF), pinacolborane (128.0 mg, $145 \mu \mathrm{L}, 1.00 \mathrm{mmol}, 2.00$ equiv.) and isopropanol (30.1 mg, $38 \mu \mathrm{L}$, $0.50 \mathrm{mmol}, 1.00$ equiv.). All reagents were added directly to a graduated Young-NMR vial. Subsequently, the glass wall was rinsed with dry THF-d8 making it a $1.25 \mathrm{~mol} / \mathrm{L}$ solution in terms of $\mathbf{1}$. The sample was then continuously monitored by ${ }^{1} \mathrm{H}-\mathrm{NMR}$ spectroscopy.

The calculated data was then compared to the monitoring data using catalyst $\mathbf{C 1}^{[2]}$ and $\mathbf{C 1 - C l}$.

Using the standard catalyst $\mathbf{C 1}$, the catalytic reduction of acetophenone $\mathbf{1}$ proceeds fastest, followed by C1-Cl. The catalytic reduction proceeds slowest using the catalyst C1-I with aluminum iodide center and iodide counter ion (see fig. S22).

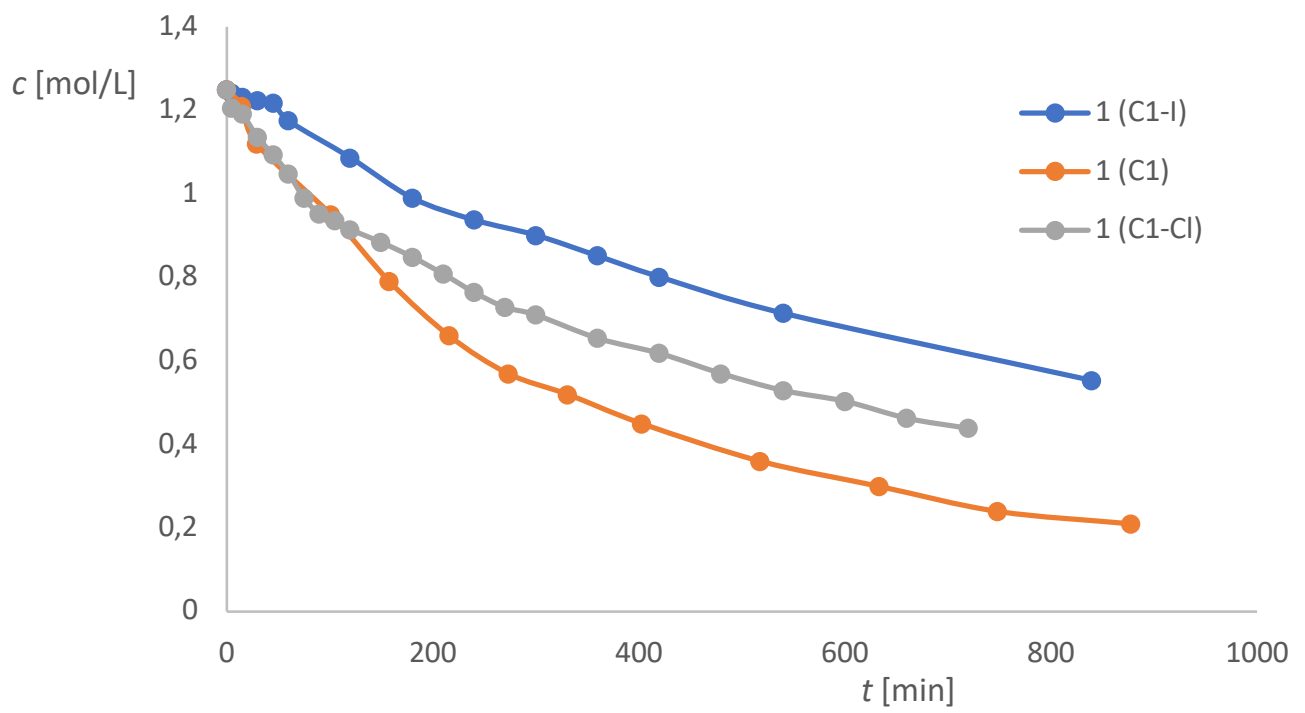

Figure S22: Conversion of 1: comparison of C1-I, C1-Cl and $\mathbf{C 1}$ as catalysts.

While after approx. $12 \mathrm{~h}$ reaction time almost the same amount of free product alcohol 2 was present in the reaction solutions using the catalysts C1-Cl and C1-I (see fig. S23), however, the concentration of the esterified product alcohol 2BPin was found to be considerably higher (see fig. S24). Considering the total concentration of product alcohol $\mathbf{2}$ and $\mathbf{2 B P i n}$ together in the reaction solution, it becomes clear 
that chloride ions are necessary for the high activity of the catalytic reaction and at the same time are responsible for the faster esterification of the product alcohol 2.

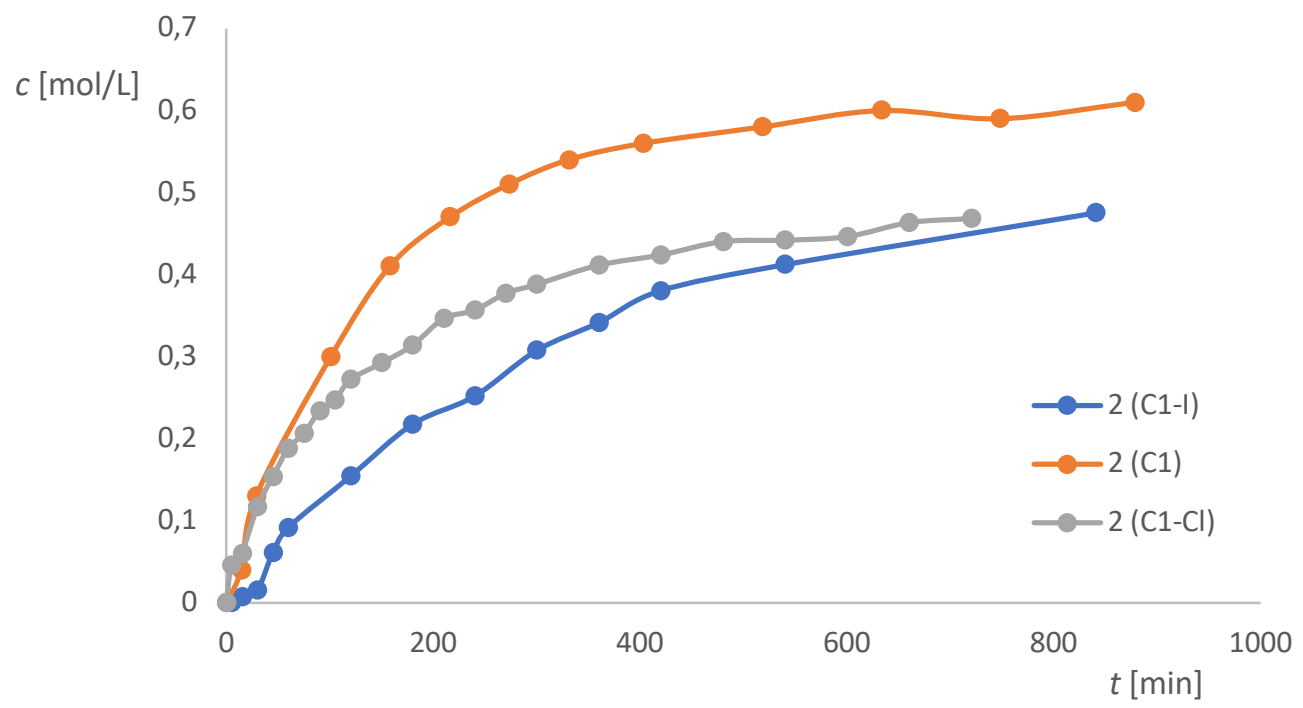

Figure S23: Formation of 2: comparison of C1-I, C1-Cl and C1 as catalysts.

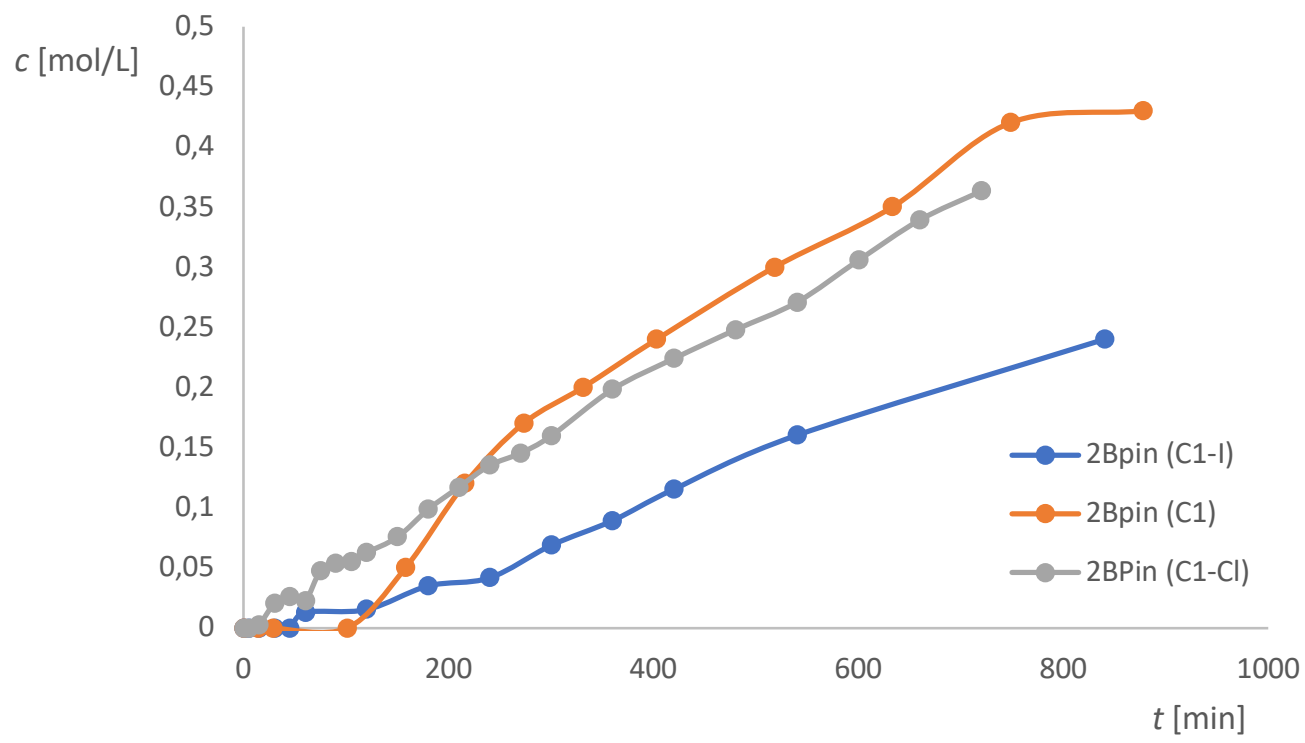

Figure S24: Formation of 2BPin: comparison of C1-I, C1-Cl and $\mathbf{C 1}$ as catalysts. 
The conversion of isopropanol proceeds slower using the catalyst C1-I compared to C1 and C1-CI (see fig. S25).

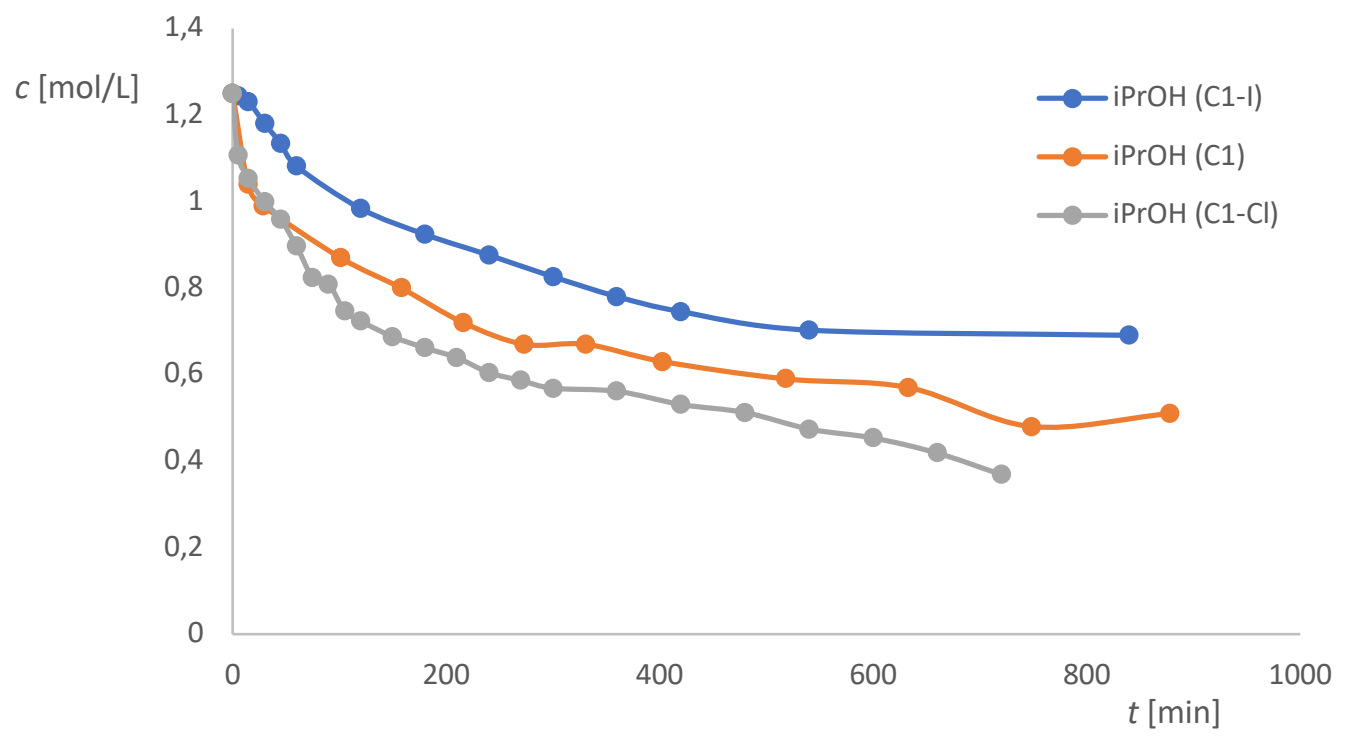

Figure S25: $\quad$ Conversion of isopropanol: comparison of C1-I, C1-Cl and C1 as catalysts.

The formation of ${ }^{i}$ PrOBPin proceeds slower using the catalyst C1-I (see fig. S26).

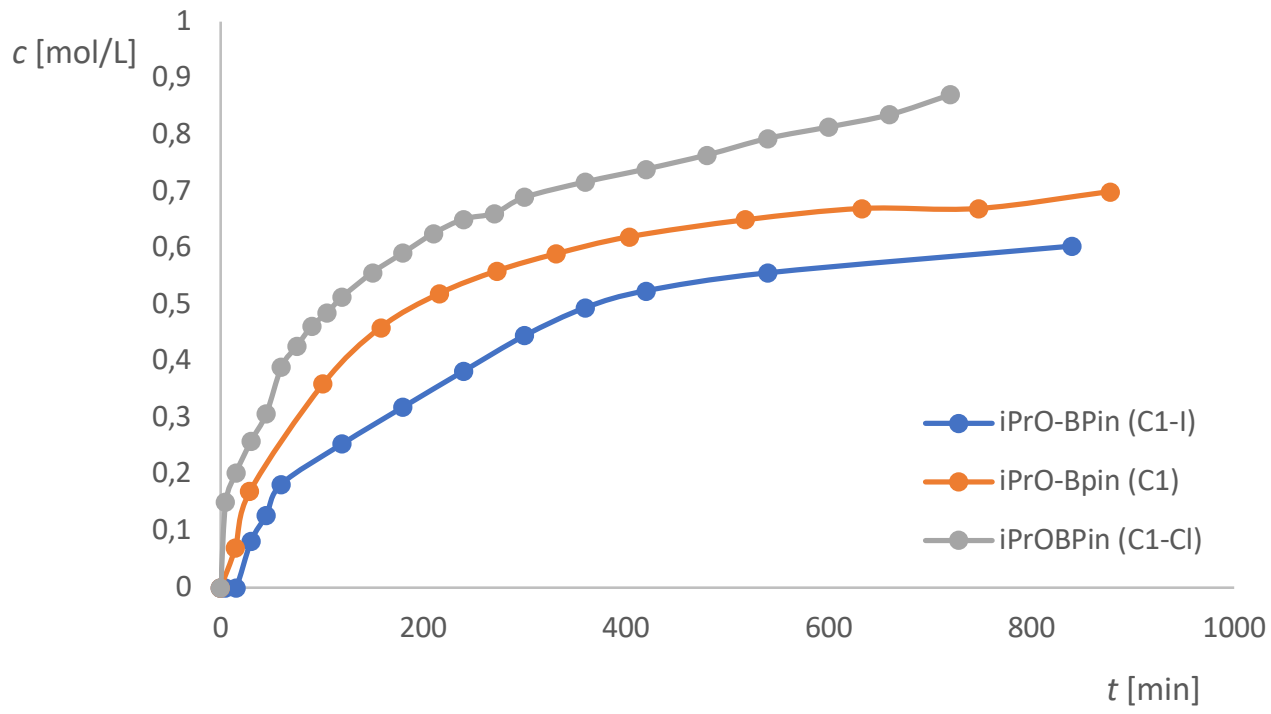

Figure S26: $\quad$ Formation of ${ }^{i}$ PrOBPin: comparison of $\mathbf{C 1}-\mathbf{I}, \mathbf{C} 1-\mathrm{Cl}$ and $\mathbf{C 1}$ as catalysts. 
Also, the conversion of HBPin proceeds slower using the catalyst C1-I compared to C1 and C1-CI (see fig. S27).

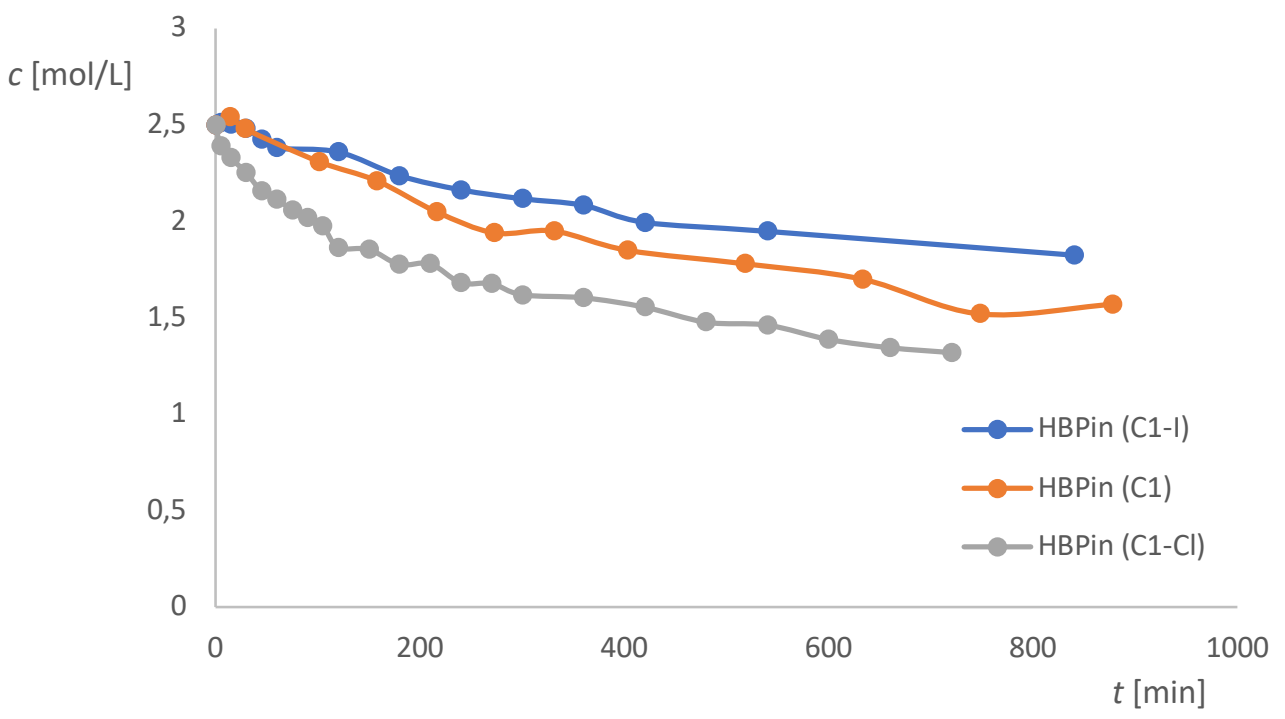

Figure S27: Conversion of HBPin: comparison of C1-I, C1-Cl and C1 as catalysts.

Table S13: $\quad$ Calculated concentration data for the reaction progress using $\mathbf{C 1}-\mathbf{I}$ as catalyst.

\begin{tabular}{ccccccc}
\hline $\begin{array}{c}t \\
{[\mathrm{~min}]}\end{array}$ & $\begin{array}{c}c(\mathbf{1}) \\
{[\mathrm{mol} / \mathrm{L}]}\end{array}$ & $\begin{array}{c}c(\mathbf{2}) \\
{[\mathrm{mol} / \mathrm{L}]}\end{array}$ & $\begin{array}{c}c(\mathbf{2 B P i n}) \\
{[\mathrm{mol} / \mathrm{L}]}\end{array}$ & $\begin{array}{c}c(\text { PrOH }) \\
{[\mathrm{mol} / \mathrm{L}]}\end{array}$ & $\begin{array}{c}c(\text { PrOBPin }) \\
{[\mathrm{mol} / \mathrm{L}]}\end{array}$ & $\begin{array}{c}c(\mathbf{H B P i n}) \\
{[\mathrm{mol} / \mathrm{L}]}\end{array}$ \\
\hline 0 & 1.25 & 0 & 0 & 1.25 & 0 & 2.5 \\
5 & 1.24 & 0 & 0 & 1.24 & 0 & 2.51 \\
15 & 1.23 & 0.01 & 0 & 1.23 & 0 & 2.50 \\
30 & 1.22 & 0.02 & 0 & 1.181 .13 & 0.08 & 2.48 \\
45 & 1.22 & 0.06 & 0 & 1.08 & 0.13 & 2.43 \\
60 & 1.17 & 0.09 & 0.01 & 0.98 & 0.18 & 2.37 \\
120 & 1.09 & 0.15 & 0.02 & 0.92 & 0.25 & 2.36 \\
180 & 0.99 & 0.22 & 0.04 & 0.88 & 0.32 & 2.24 \\
240 & 0.94 & 0.25 & 0.04 & 0.83 & 0.38 & 2.16 \\
300 & 0.90 & 0.31 & 0.07 & 0.78 & 0.44 & 2.11 \\
360 & 0.85 & 0.34 & 0.09 & 0.75 & 0.49 & 2.08 \\
420 & 0.80 & 0.38 & 0.12 & 0.70 & 0.52 & 1.99 \\
540 & 0.71 & 0.41 & 0.16 & 0.69 & 0.56 & 1.94 \\
840 & 0.55 & 0.48 & 0.24 & 0.63 & 0.60 & 1.82 \\
\hline
\end{tabular}



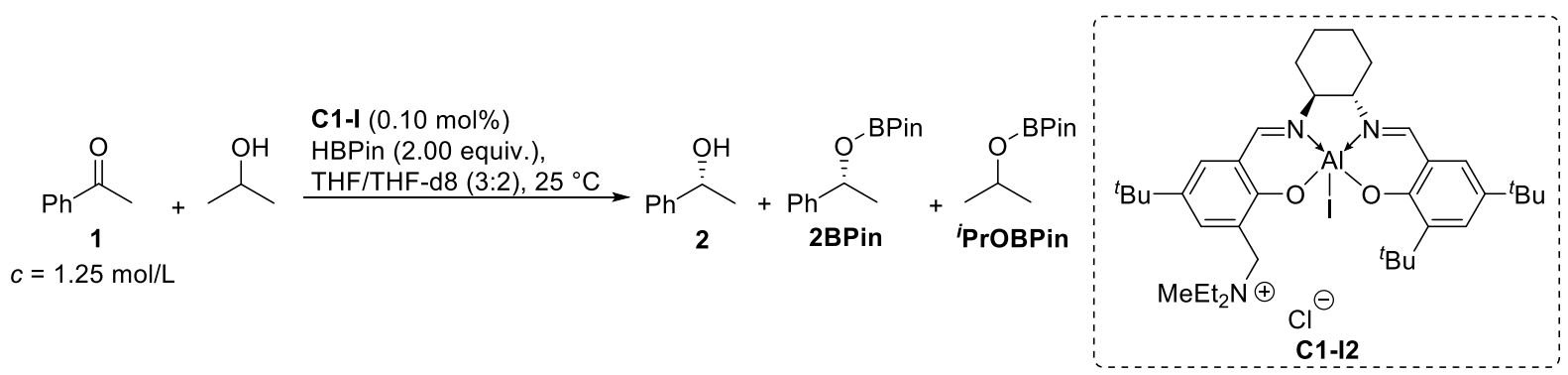

The continuous reaction monitoring followed a literature protocol ${ }^{[2]}$ using acetophenone 1 (60.1 mg, $58 \mu \mathrm{L}, \quad 0.50 \mathrm{mmol}, \quad 1.00$ equiv. $)$ catalyst $\mathbf{C 1 - I 2}(0.38 \mu \mathrm{g}, \quad 0.50 \mu \mathrm{moL}, \quad 0.10 \mathrm{~mol} \%, \quad 120 \mu \mathrm{L}$ $4.17 \mu \mathrm{moL} / \mathrm{mL}$ in THF), pinacolborane (128.0 mg, $145 \mu \mathrm{L}, 1.00 \mathrm{mmol}, 2.00$ equiv.) and isopropanol (30.1 mg, $38 \mu \mathrm{L}, 0.50 \mathrm{mmol}, 1.00$ equiv.). All reagents were added directly to a graduated Young-NMR vial. Subsequently, the glass wall was rinsed with dry THF-d8 making it a $1.25 \mathrm{~mol} / \mathrm{L}$ solution in terms of $\mathbf{1}$. The sample was then continuously monitored by ${ }^{1} \mathrm{H}-\mathrm{NMR}$ spectroscopy.

The calculated data was then compared to the monitoring data using catalyst $\mathbf{C 1} .^{[2]}$

Using the catalyst C1-I2, acetophenone is converted just as quickly as using the standard catalyst $\mathbf{C 1}$ (see fig. S28). Here, only the positions of the halides on the catalyst have been exchanged. While $\mathbf{C 1}$ has an aluminum chloride metal center and an ammonium iodide unit, the catalyst C1-I2 conversely has an aluminum iodide metal center and an ammonium chloride unit.

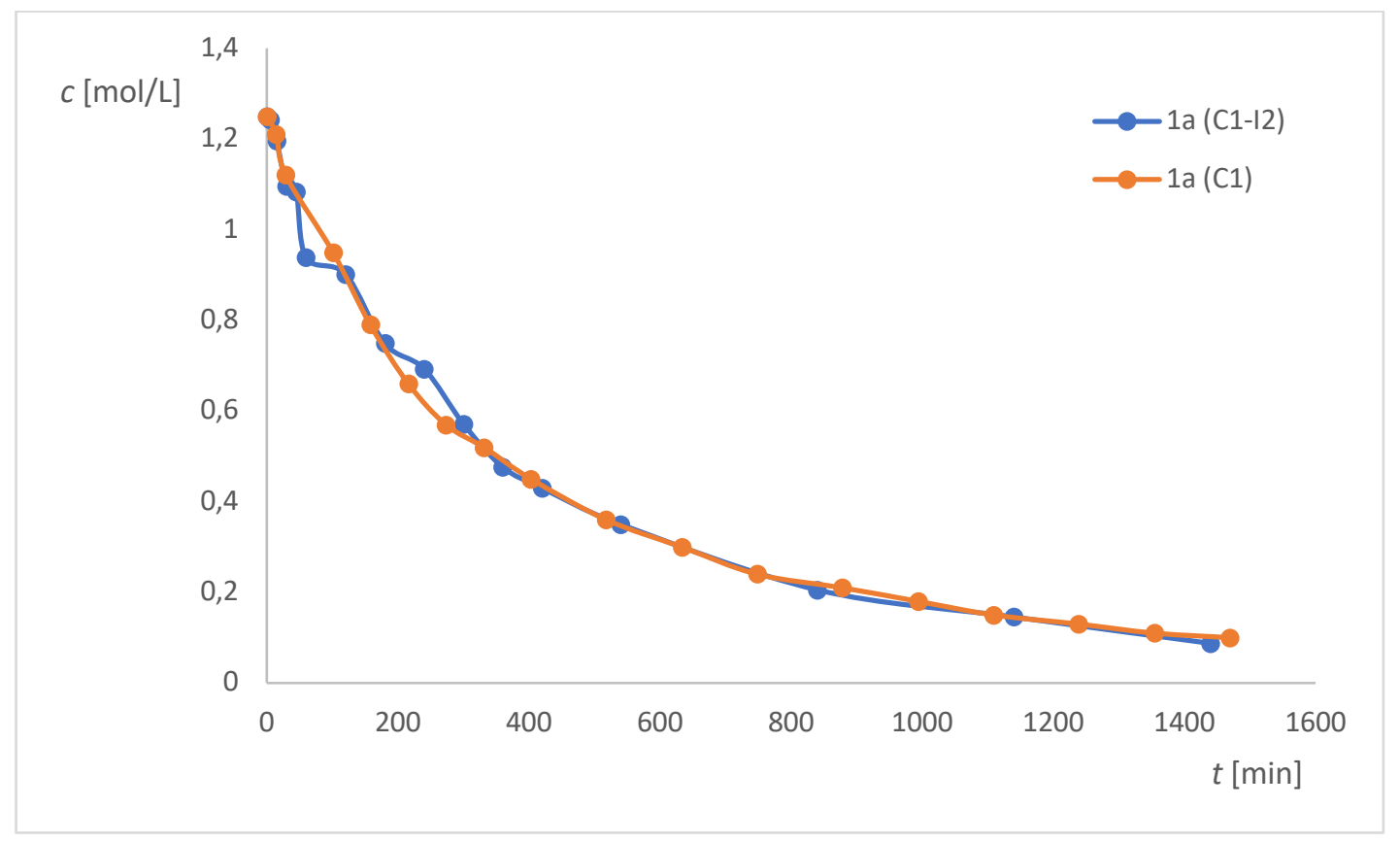

Figure S28: $\quad$ Conversion of 1: comparison of C1-I2 and C1 as catalysts. 
Table S14: $\quad$ Calculated concentration data for the reaction progress using C1-I2 as catalyst.

\begin{tabular}{cc}
\hline $\begin{array}{c}t \\
{[\mathrm{~min}]}\end{array}$ & $\begin{array}{c}c(\mathbf{1}) \\
{[\mathrm{mol} / \mathrm{L}]}\end{array}$ \\
\hline 0 & 1.25 \\
5 & 1.24 \\
15 & 1.19 \\
30 & 1.10 \\
45 & 1.08 \\
60 & 0.94 \\
120 & 0.90 \\
180 & 0.75 \\
240 & 0.69 \\
300 & 0.57 \\
360 & 0.47 \\
420 & 0.43 \\
540 & 0.34 \\
840 & 0.21 \\
1140 & 0.15 \\
1440 & 0.09 \\
\hline
\end{tabular}




\section{Continuous Reaction Monitoring of the Asymmetric Reduction of Acetophenone with Pinacolborane, $\mathrm{C} 1$ and 2 as Proton Source by ${ }^{1} \mathrm{H}-\mathrm{NMR}$ Spectroscopy}

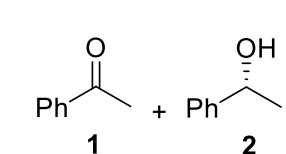

$c=1.25 \mathrm{~mol} / \mathrm{L}$

2
C1 $(0.10 \mathrm{~mol} \%)$

HBPin (2.00 equiv.), THF/THF-d8 (3:2), $25^{\circ} \mathrm{C}$

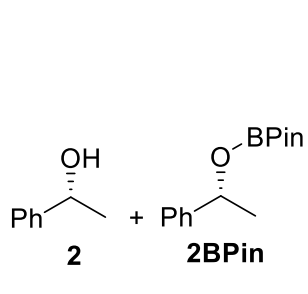

2BPin

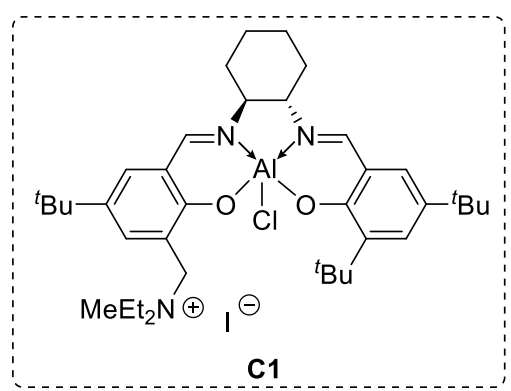

The continuous reaction monitoring followed a literature protocol ${ }^{[2]}$ using acetophenone 1 (60.1 $\mathrm{mg}$, $58 \mu \mathrm{L}, 0.50 \mathrm{mmol}, 1.00$ equiv.), catalyst $\mathbf{C 1}(0.38 \mu \mathrm{g}, 0.50 \mu \mathrm{moL}, 0.10 \mathrm{~mol} \%, 120 \mu \mathrm{L} 4.17 \mu \mathrm{moL} / \mathrm{mL}$ in THF), pinacolborane (128.0 mg, $145 \mu \mathrm{L}, 1.00 \mathrm{mmol}, 2.00$ equiv.) and $2(61.0 \mathrm{mg}, 60 \mu \mathrm{L}, 0.50 \mathrm{mmol}$, 1.00 equiv.). All reagents were added directly to a graduated Young-NMR vial. Subsequently, the glass wall was rinsed with dry THF-d8 making it a $1.25 \mathrm{~mol} / \mathrm{L}$ solution in terms of $\mathbf{1}$. The sample was then continuously monitored by ${ }^{1} \mathrm{H}-\mathrm{NMR}$ spectroscopy.

The calculated data was then compared to the monitoring data using catalyst $\mathbf{C 1} \mathbf{1}^{[2]}$

Using the product alcohol $\mathbf{2}$ as a proton source instead of isopropanol, acetophenone $\mathbf{1}$ is converted at the same rate (see fig. S29). At the same time, the experiment shows that the product alcohol 2 serves as a proton source in the reaction.

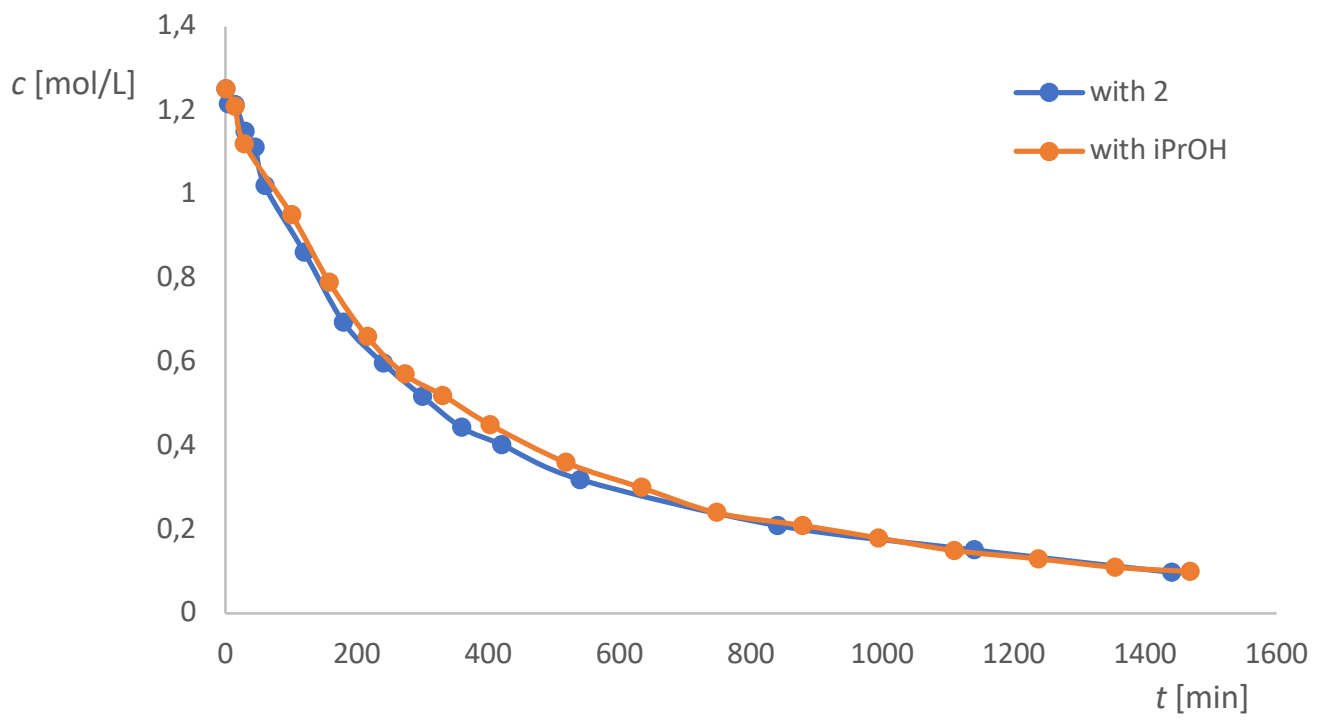

Figure S29: $\quad$ Conversion of $\mathbf{1}$ with catalyst $\mathbf{C 1}$ : comparison of isopropanol and $\mathbf{2}$ as proton sources.

During the reaction, the concentration of $\mathbf{2}$ is decreasing (see fig S30) because of the increasing esterification of $\mathbf{2}$ to $\mathbf{2 B P i n}$ (see fig. S31). 


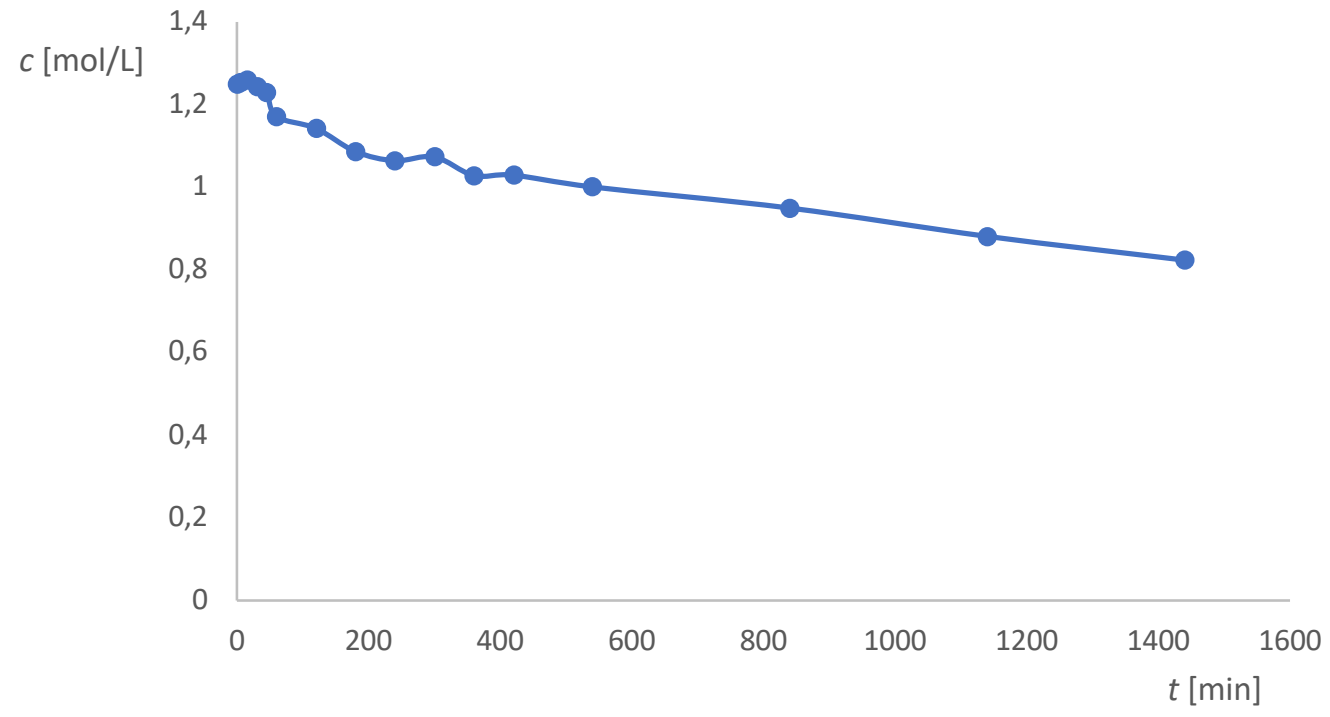

Figure S30: $\quad$ Conversion of 2.

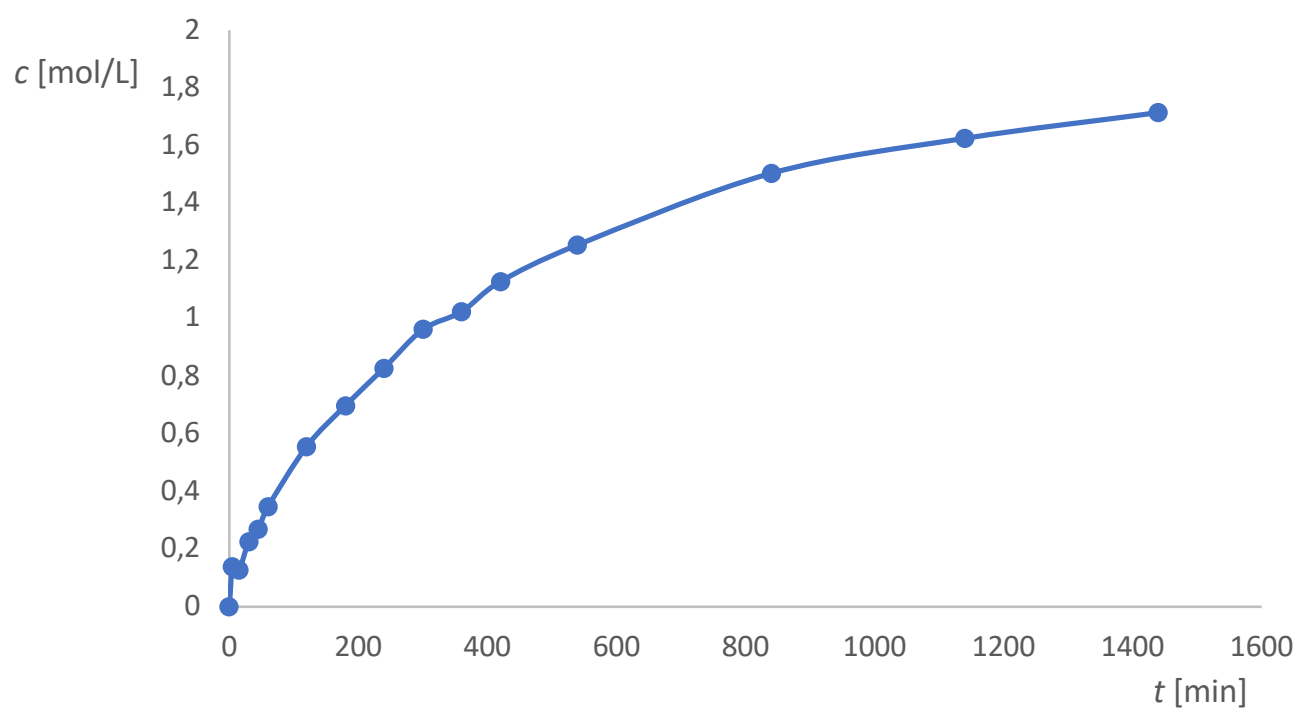

Figure S31: $\quad$ Formation of 2BPin. 
Table S15: $\quad$ Calculated concentration data for the reaction progress using $\mathbf{C} \mathbf{1}$ as catalyst and $\mathbf{2}$ as proton source.

\begin{tabular}{cccc}
\hline $\begin{array}{c}t \\
{[\mathrm{~min}]}\end{array}$ & $\begin{array}{c}c(\mathbf{1}) \\
{[\mathrm{mol} / \mathrm{L}]}\end{array}$ & $\begin{array}{c}c(\mathbf{2}) \\
{[\mathrm{mol} / \mathrm{L}]}\end{array}$ & $\begin{array}{c}c(\mathbf{2 B P i n}) \\
{[\mathrm{mol} / \mathrm{L}]}\end{array}$ \\
\hline 0 & 1.25 & 1.25 & 0 \\
5 & 1.22 & 1.25 & 0.14 \\
15 & 1.21 & 1.26 & 0.13 \\
30 & 1.15 & 1.24 & 0.23 \\
45 & 1.11 & 1.23 & 0.27 \\
60 & 1.02 & 1.17 & 0.35 \\
120 & 0.86 & 1.14 & 0.56 \\
180 & 0.69 & 1.09 & 0.70 \\
240 & 0.60 & 1.06 & 0.83 \\
300 & 0.52 & 1.07 & 0.96 \\
360 & 0.44 & 1.03 & 1.02 \\
420 & 0.40 & 1.03 & 1.13 \\
540 & 0.32 & 1.00 & 1.25 \\
840 & 0.21 & 0.95 & 1.50 \\
1140 & 0.15 & 0.88 & 1.63 \\
1440 & 0.10 & 0.82 & 1.71 \\
\hline & & &
\end{tabular}




\section{Continuous Reaction Monitoring of the Asymmetric Reduction of Acetophenone with Pinacolborane and $\mathrm{C} 1$ by ${ }^{1} \mathrm{H}-\mathrm{NMR}$ Spectroscopy with Extended Reaction Time}
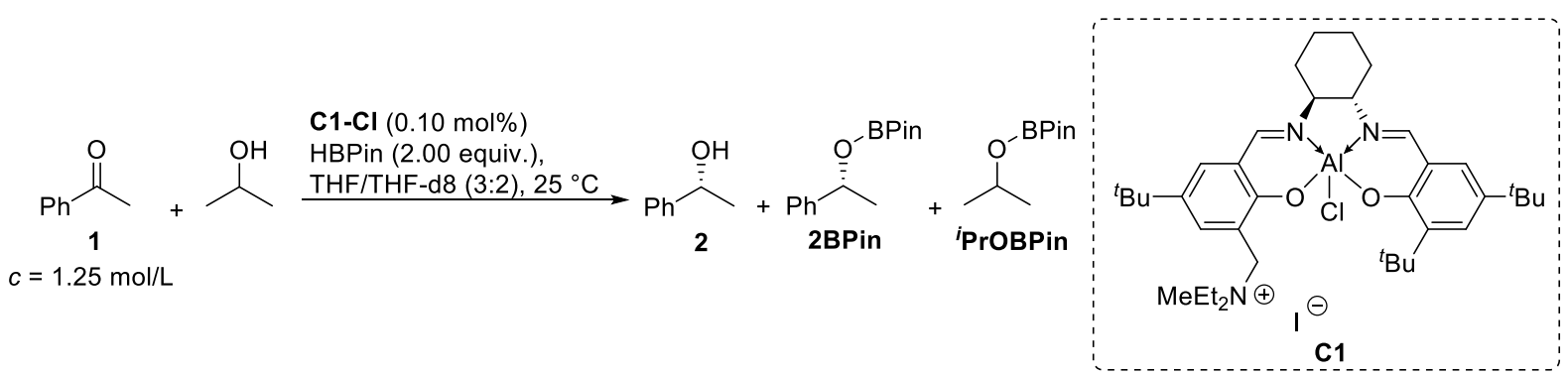

The continuous reaction monitoring followed a literature protocol ${ }^{[2]}$ using acetophenone $1(60.1 \mathrm{mg}$, $58 \mu \mathrm{L}, \quad 0.50 \mathrm{mmol}, \quad 1.00$ equiv. $)$ catalyst $\mathbf{C 1 - I 2} \quad(0.38 \mu \mathrm{g}, \quad 0.50 \mu \mathrm{moL}, \quad 0.10 \mathrm{~mol} \%, \quad 120 \mu \mathrm{L}$ $4.17 \mu \mathrm{moL} / \mathrm{mL}$ in THF), pinacolborane (128.0 mg, $145 \mu \mathrm{L}, 1.00 \mathrm{mmol}, 2.00$ equiv.) and isopropanol ( $30.1 \mathrm{mg}, 38 \mu \mathrm{L}, 0.50 \mathrm{mmol}, 1.00$ equiv.). All reagents were added directly to a graduated Young-NMR vial. Subsequently, the glass wall was rinsed with dry THF-d8 making it a $1.25 \mathrm{~mol} / \mathrm{L}$ solution in terms of $\mathbf{1}$. The sample was then continuously monitored by ${ }^{1} \mathrm{H}-\mathrm{NMR}$ spectroscopy for $90 \mathrm{~h}$ (see fig. S32).

After approx. $40 \mathrm{~h}$ of reaction time acetophenone 1 was completely converted. From $60 \mathrm{~h}$ of reaction time onwards, the concentrations of the reactants became nearly constant. The concentrations of 2BPin and ${ }^{i}$ PrOBPin seemed to align. But still after $90 \mathrm{~h}$ of reaction time the concentration of ${ }^{i}$ PrOBPin remained higher than the concentration of 2BPin (see fig. S32).

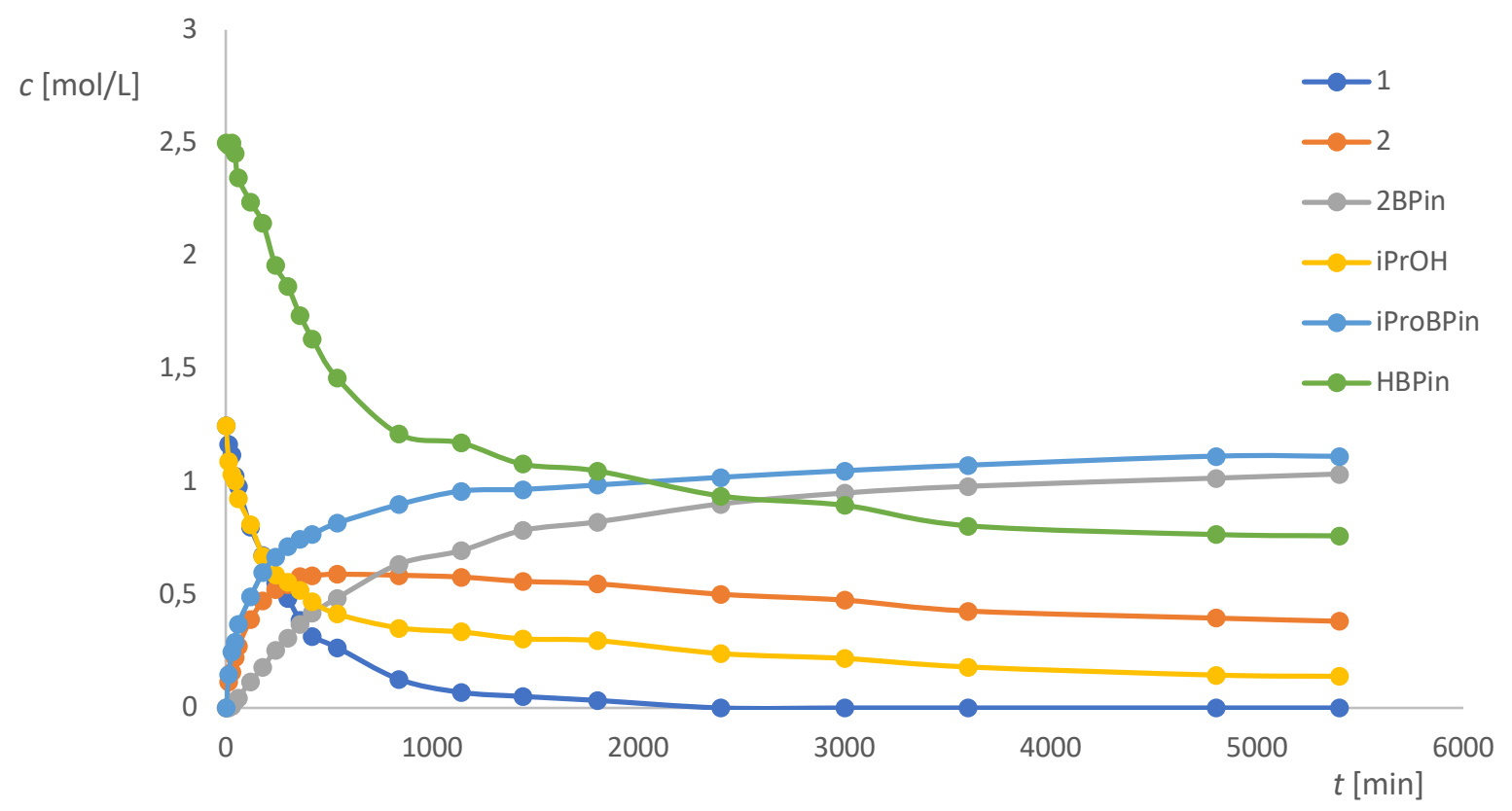

Figure S32: Continuous monitoring of the catalytic reduction of acetophenone 1 by ${ }^{1} \mathrm{H}-\mathrm{NMR}$ spectroscopy over a reaction time of $90 \mathrm{~h}$. 
Table S16: Calculated concentration data for the reaction progress with extended reaction time using catalyst C1.

\begin{tabular}{|c|c|c|c|c|c|c|}
\hline $\begin{array}{c}t \\
{[\mathrm{~min}]}\end{array}$ & $\begin{array}{c}c(\mathbf{1}) \\
{[\mathrm{mol} / \mathrm{L}]}\end{array}$ & $\begin{array}{c}c(\mathbf{2}) \\
{[\mathrm{mol} / \mathrm{L}]}\end{array}$ & $\begin{array}{c}c \text { (2BPin) } \\
{[\mathrm{mol} / \mathrm{L}]}\end{array}$ & $\begin{array}{c}c\left({ }^{i} \mathrm{PrOH}\right) \\
{[\mathrm{mol} / \mathrm{L}]}\end{array}$ & $\begin{array}{c}c\left({ }^{i} \text { PrOBPin }\right) \\
{[\mathrm{mol} / \mathrm{L}]}\end{array}$ & $\begin{array}{c}c \text { (HBPin) } \\
{[\mathrm{mol} / \mathrm{L}]}\end{array}$ \\
\hline 0 & 1.25 & 0 & 0 & 1.25 & 0 & 2.5 \\
\hline 15 & 1.17 & 0.12 & 0 & 1.09 & 0.15 & 2.49 \\
\hline 30 & 1.12 & 0.16 & 0.01 & 1.04 & 0.25 & 2.50 \\
\hline 45 & 1.03 & 0.22 & 0.03 & 1.00 & 0.29 & 2.45 \\
\hline 60 & 0.98 & 0.27 & 0.04 & 0.93 & 0.37 & 2.35 \\
\hline 5120 & 0.80 & 0.39 & 0.12 & 0.81 & 0.49 & 2.24 \\
\hline 180 & 0.68 & 0.47 & 0.18 & 0.67 & 0.0 & 2.14 \\
\hline 240 & 0.55 & 0.52 & 0.25 & 0.59 & 0.67 & 1.96 \\
\hline 300 & 0.48 & 0.55 & 0.31 & 0.56 & 0.71 & 1.87 \\
\hline 360 & 0.39 & 0.58 & 0.37 & 0.52 & 0.75 & 1.74 \\
\hline 420 & 0.32 & 0.58 & 0.42 & 0.47 & 0.77 & 1.63 \\
\hline 540 & 0.27 & 0.59 & 0.49 & 0.42 & 0.82 & 1.45 \\
\hline 840 & 0.13 & 0.59 & 0.64 & 0.35 & 0.90 & 1.21 \\
\hline 1140 & 0.07 & 0.58 & 0.69 & 0.34 & 0.96 & 1.17 \\
\hline 1440 & 0.05 & 0.56 & 0.79 & 0.31 & 0.97 & 1.08 \\
\hline 1800 & 0.03 & 0.55 & 0.82 & 0.30 & 0.99 & 1.05 \\
\hline 2400 & 0 & 0.50 & 0.90 & 0.24 & 1.02 & 0.94 \\
\hline 3000 & 0 & 0.48 & 0.95 & 0.22 & 1.05 & 0.90 \\
\hline 3600 & 0 & 0.43 & 0.98 & 0.18 & 1.07 & 0.80 \\
\hline 4800 & 0 & 0.40 & 1.02 & 0.15 & 1.11 & 0.77 \\
\hline 5400 & 0 & 0.38 & 1.03 & 0.14 & 1.11 & 0.76 \\
\hline
\end{tabular}




\section{Continuous Reaction Monitoring of the Esterification of Isopropanol with Pinacolborane and $\mathrm{C} 1$ by ${ }^{1} \mathrm{H}-\mathrm{NMR}$ under Standard Conditions}
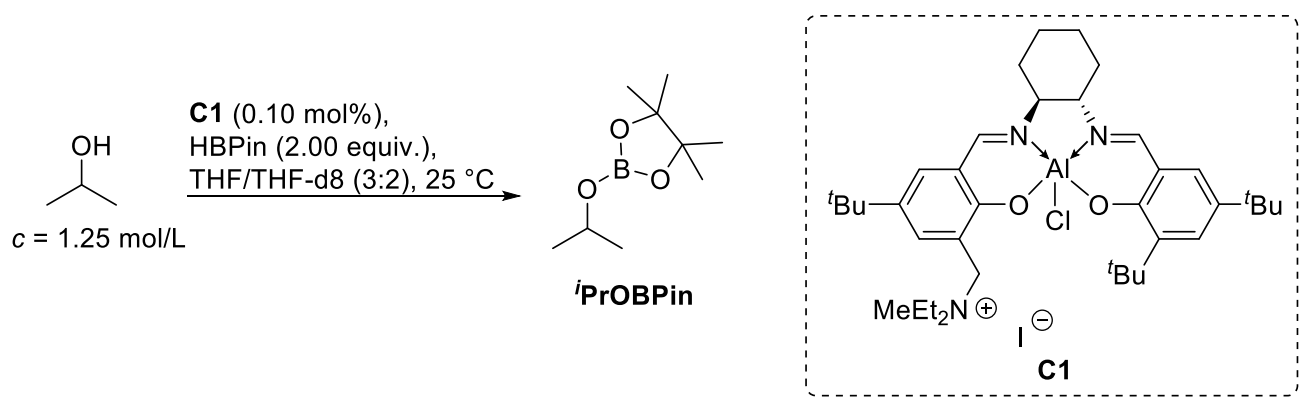

The continuous reaction monitoring was performed according to GP4 using isopropanol (30.1 $\mathrm{mg}$, $38 \mu \mathrm{L}, 0.50 \mathrm{mmol}, 1.00$ equiv.), catalyst $\mathbf{C 1}(0.38 \mu \mathrm{g}, 0.50 \mu \mathrm{moL}, 0.10 \mathrm{~mol} \%, 120 \mu \mathrm{L}, 4.17 \mu \mathrm{moL} / \mathrm{mL}$ in THF) and pinacolborane (128.0 mg, $145 \mu \mathrm{L}, 1.00 \mathrm{mmol}, 2.00$ equiv.).

The recorded data is in accordance with the literature. ${ }^{[5]}$

The concentration profile of HBPin for the esterification of isopropanol is compared with the concentration profile of the catalytic reduction of acetophenone 1 under standard conditions ${ }^{[2]}$ (see fig. S33).

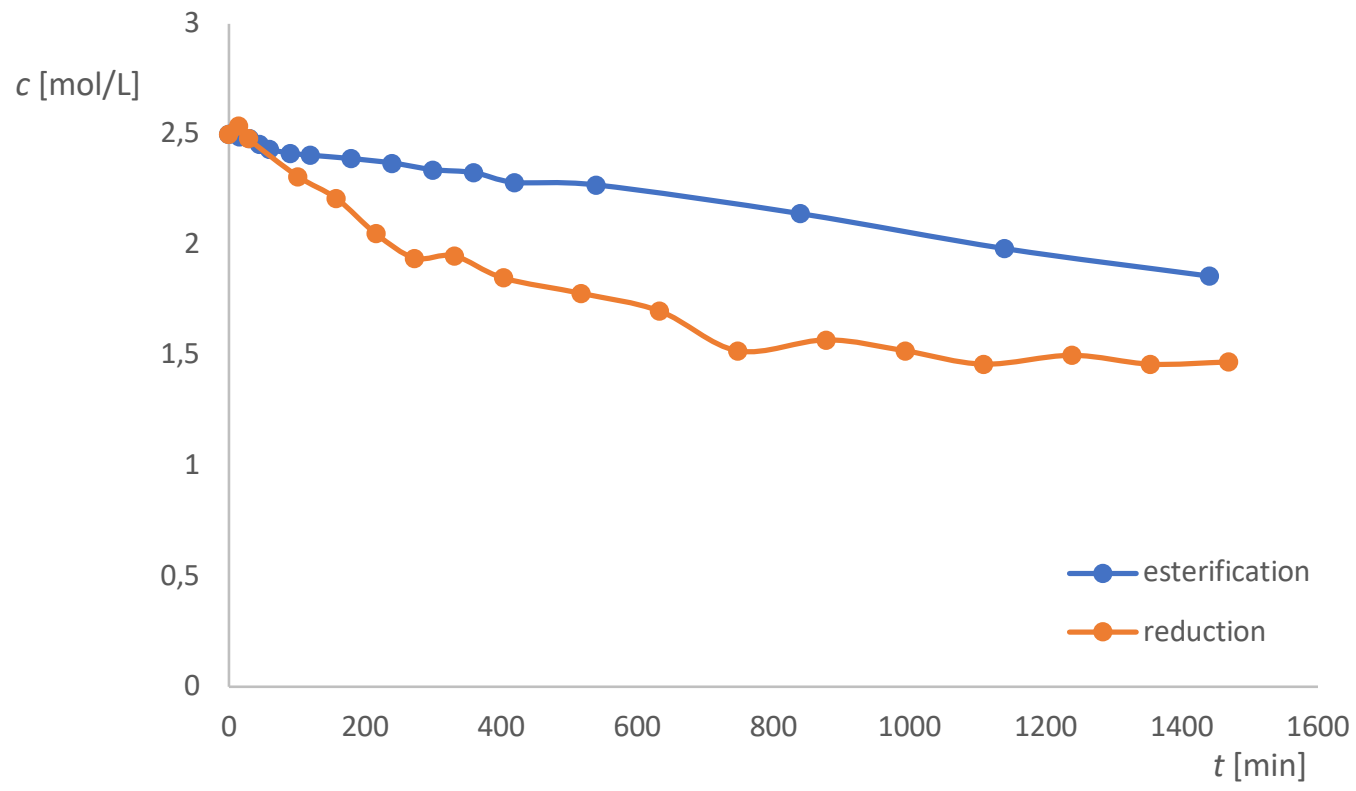

Figure S33: Conversion of HBPin: comparison of the conversion during the esterification and asymmetric reduction. 
The amount of consumed HBPin seems to be low at the beginning with 5\% conversion after $4 \mathrm{~h}$ of reaction time. After $24 \mathrm{~h}$ of reaction time, however, $26 \%$ of the HBPin has already been consumed due to the side reaction. Considering that the product alcohol 2 also consumes HBPin via the side reaction and that $20 \%$ ester $\mathbf{2 B P i n}$ is formed after $24 \mathrm{~h}$ (compare fig. S10), a non-negligible amount of HBPin is consumed over the course of the catalytic reaction.

Table S17: Calculated concentration data for the progressing esterification of isopropanol using $\mathbf{C 1}$ as catalyst under standard conditions.

\begin{tabular}{cc}
\hline $\begin{array}{c}t \\
{[\mathrm{~min}]}\end{array}$ & $\begin{array}{c}c \text { (2BPin) } \\
{[\mathrm{mol} / \mathrm{L}]}\end{array}$ \\
\hline 0 & 2.50 \\
5 & 2.50 \\
15 & 2.49 \\
30 & 2.48 \\
45 & 2.46 \\
60 & 2.43 \\
90 & 2.42 \\
120 & 2.41 \\
180 & 2.39 \\
240 & 2.37 \\
300 & 2.34 \\
360 & 2.33 \\
420 & 2.28 \\
540 & 2.27 \\
840 & 2.14 \\
1140 & 1.98 \\
1440 & 1.86 \\
\hline
\end{tabular}




\section{NMR Spectra}

1-(5-(tert-Butyl)-3-((E)-(((1S,2S)-2-(((E)-3,5-di-tert-butyl-2-

hydroxybenzylidene)amino)cyclohexyl)imino)methyl)-2-hydroxybenzyl)- $N, N$-diethyl-Nmethylmethanammonium Triflate (L1-OTf)
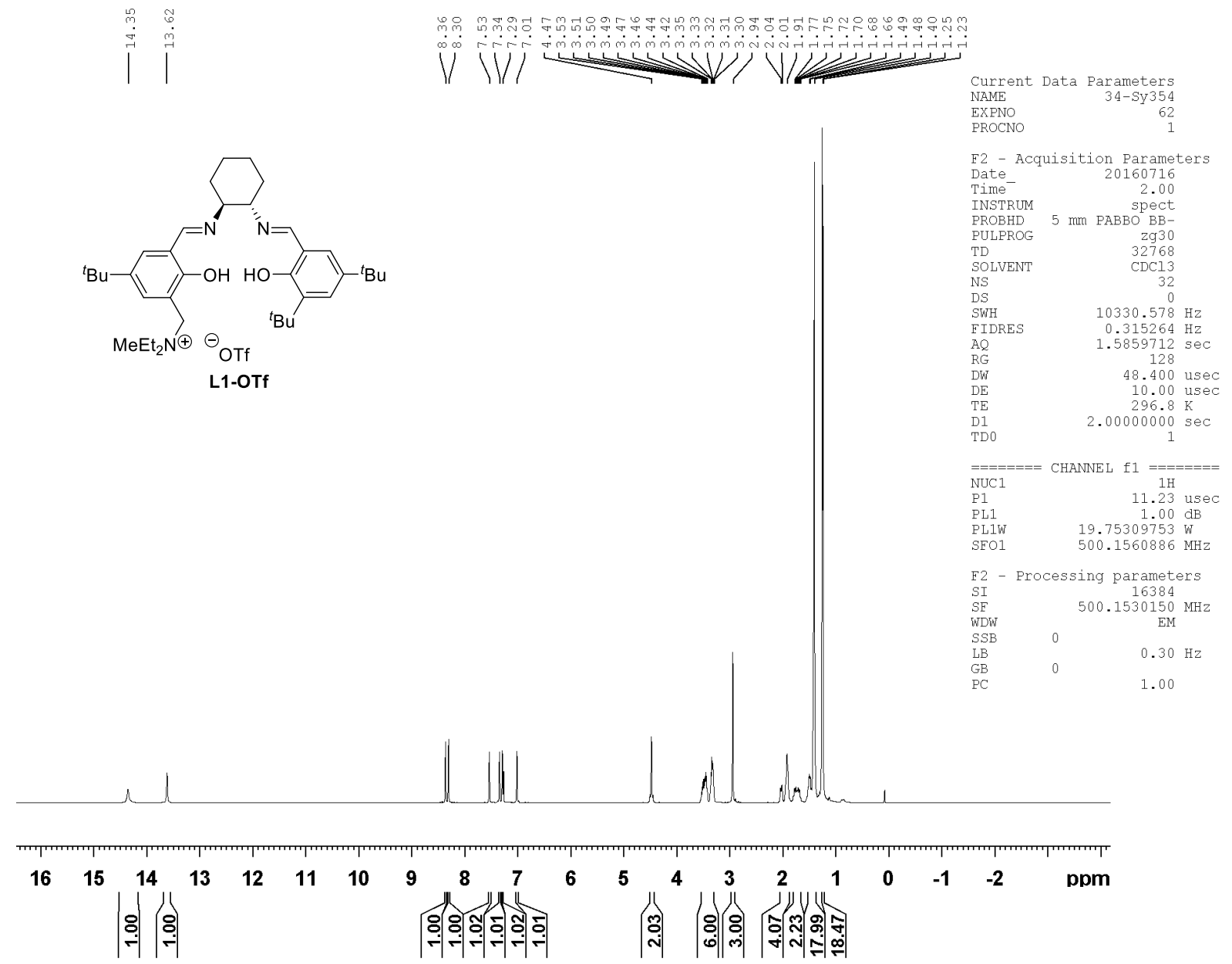

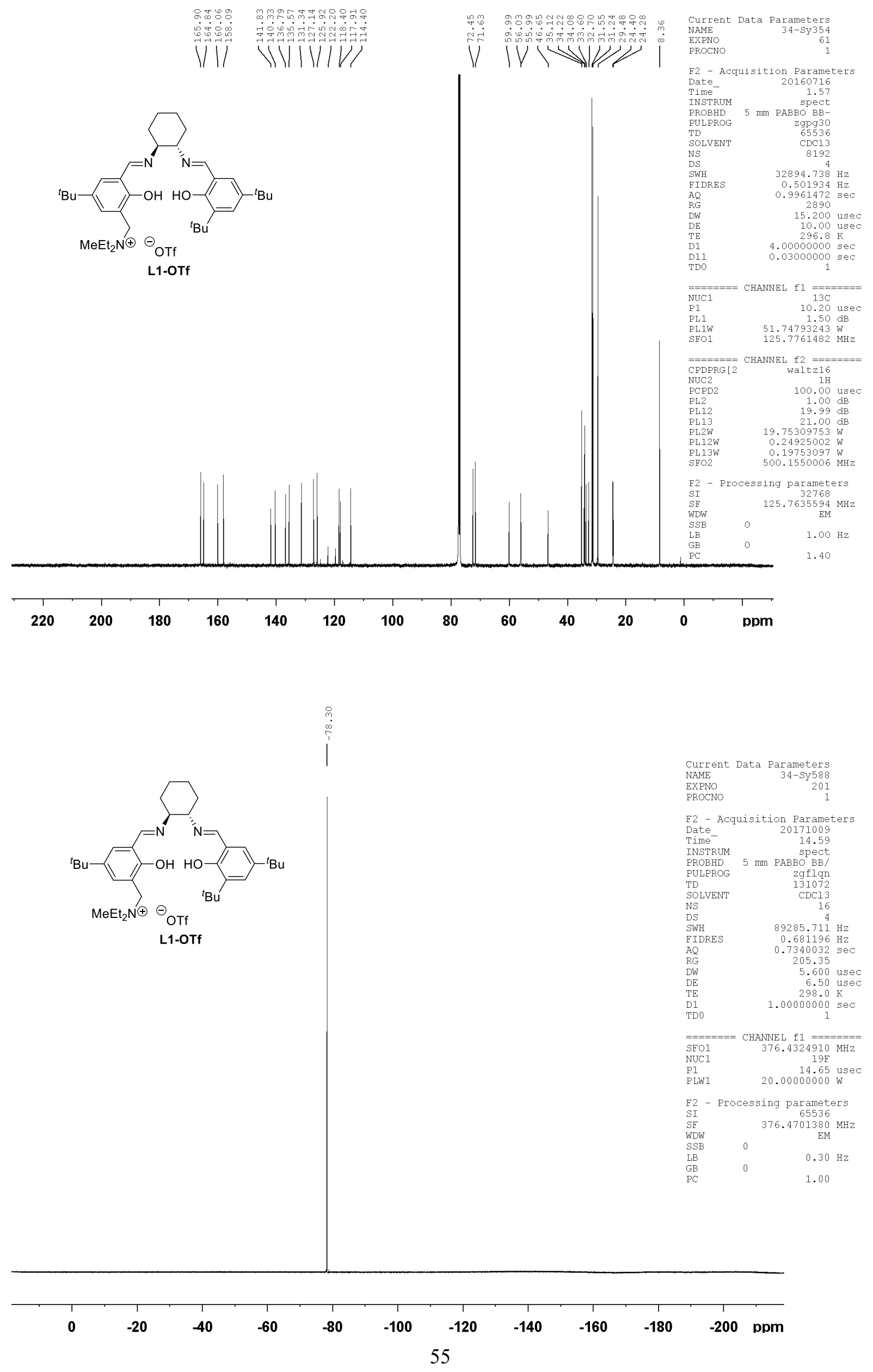
$N$-(5-(tert-Butyl)-3-((E)-(((1S,2S)-2-(((E)-3,5-di-tert-butyl-2-hydroxybenzylidene)amino)cyclohexyl)imino)methyl)-2-hydroxybenzyl)-N-diethyl-N-

methylmethanammonium Tetrakis[3,5-bis(trifluoromethyl)phenyl]borate (L1-BArF)
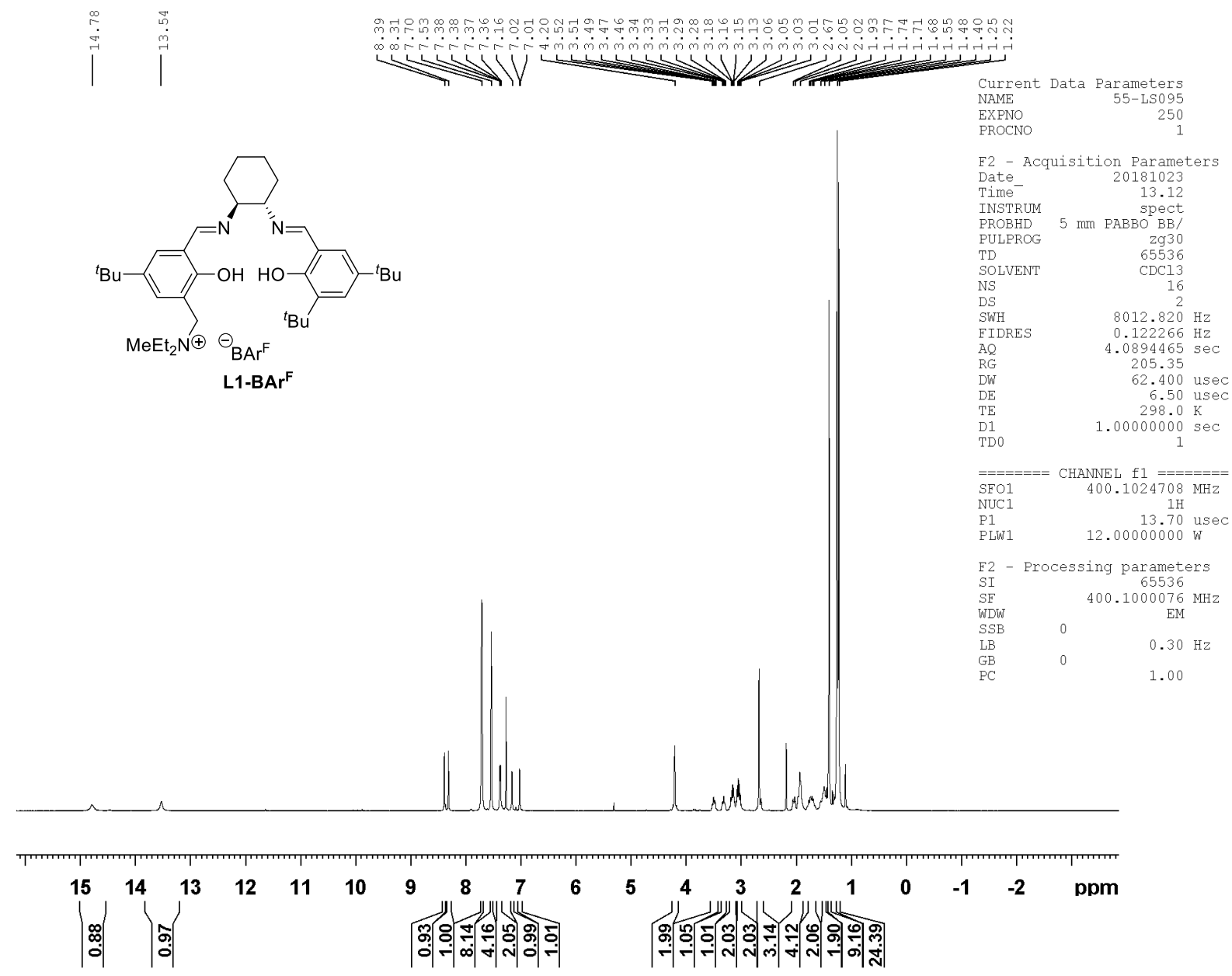

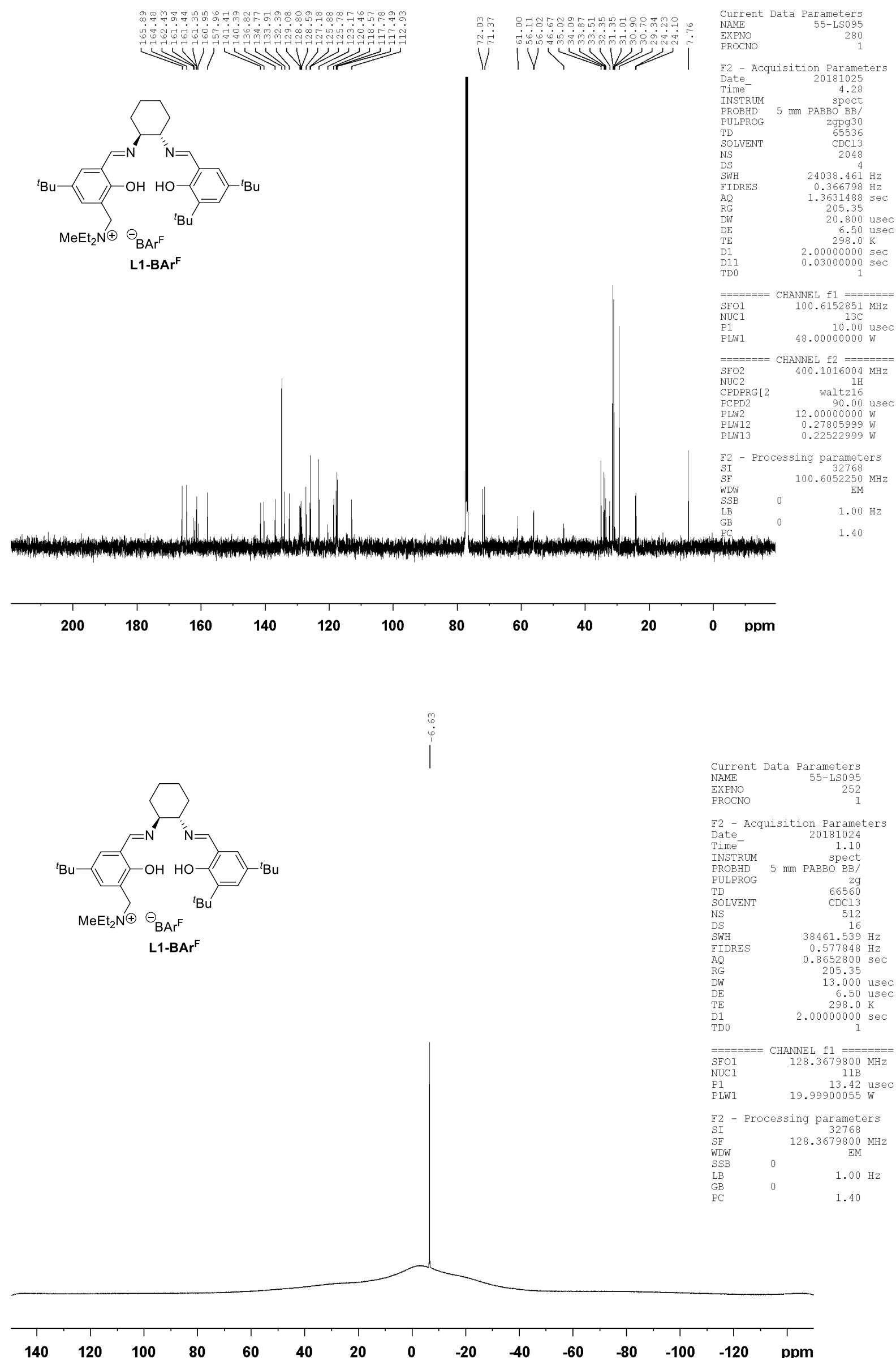


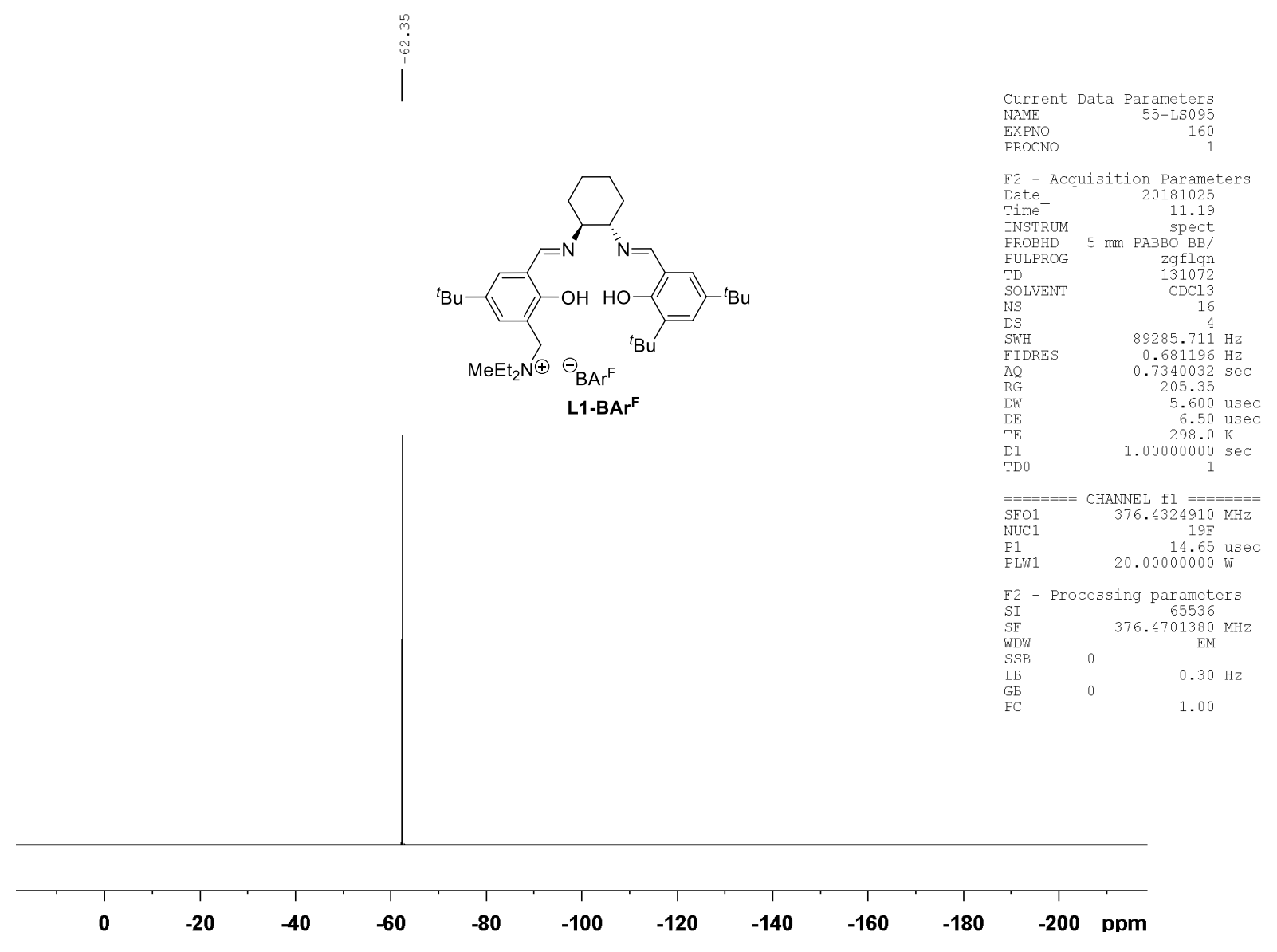




\section{Quantum Chemical Investigations}

\section{Reliability of gas-phase structures}

Benchmark calculations have been performed for SR7Cl in order to test the reliability of gas-phase structures in the present ionic reactions. Herein, the same computational details as described in the manuscript have been applied for SR7CI_GAS. For the values SR7CI_COSMO additionally the COSMO approach has been implemented in the geometry optimization. The results in Table S18 show that this has a negligible effect on the Gibbs free energies and that the gas-phase structures are reliable for the present ionic reactions.

Table S18: $\quad$ Benchmark studies on the reliability of gas phase structures exemplary on the reaction SR7CI.

\begin{tabular}{cc}
\hline Reaction & $\Delta \mathrm{G}\left[\mathrm{kJ} \mathrm{mol}^{-1}\right]$ \\
\hline SR7Cl_GAS & 98.8 \\
SR7Cl_COSMO & 100.1
\end{tabular}

\section{Molecular Geometries of the states calculated by DFT}

In the following all cartesian coordinates for all geometries are listed in xyz format:

\section{Main Catalytic Cycle}

\section{Cat}
Al $0.9562460 .736474-2.049635$
O $1.590928-0.872373-1.503780$
$\mathrm{N} \quad 1.7997161 .622276-0.493815$
C $1.4164503 .029728-0.305510$
H $\quad 0.4960043 .0190980 .309590$
O $\quad-0.653168-0.030978-2.328602$
N $\quad 0.0929892 .541785-2.213250$
C $0.9953433 .560945-1.689845$
H $\quad 1.8866413 .554473-2.344455$
C $\quad 0.4526074 .977891-1.586792$
H $\quad-0.4509684 .970251-0.952439$
H $\quad 0.1648335 .347439-2.583494$
$\mathrm{N} \quad-2.599201-2.098630-0.504385$
C $1.5124985 .888697-0.966815$
H $\quad 1.1248206 .914429-0.887237$
H $2.3920965 .930574-1.631892$
C $\quad 1.9372905 .3739320 .406551$
H 1.0694905 .4065211 .085802 

H $\quad 2.7080586 .0272020 .840200$
C 2.4576473 .9358880 .340684
H $3.3956113 .884417-0.239450$
H 2.6852403 .5971561 .361409
C 2.6515631 .0558750 .289433
H 3.1223291 .6574281 .076202
C $3.079659-0.3229590 .249887$
C $\quad 2.549920-1.235382-0.69994$
C $3.083385-2.560283-0.770105$
C $4.071850-2.9073590 .144125$
H $\quad 4.492468-3.9124380 .115250$
C $4.574317-2.0151011 .108488$
C $4.083913-0.7270331 .149105$
H $4.476574-0.0002981 .864309$
C $-1.1120122 .800708-2.558356$
H $\quad-1.4622243 .840665-2.584832$
C $\quad-2.1199531 .793040-2.827250$
C $\quad-1.8507960 .428341-2.545854$
C $\quad-2.948080-0.463871-2.450969$
C $-4.228852-0.023594-2.783743$
H $\quad-5.059524-0.734021-2.759817$
C $-4.4782261 .301889-3.142233$
C $\quad-3.4241242 .204912-3.122027$
H $\quad-3.6091693 .265621-3.307476$
C $\quad-2.687935-1.871852-2.019340$
H $\quad-3.486970-2.536774-2.370535$
H $\quad-1.723906-2.224291-2.410153$
C $\quad-3.765922-1.4760570 .222619$
H $\quad-3.749991-0.408906-0.044467$
$\mathrm{H} \quad-3.515064-1.5174061 .290356$
C $\quad-2.535455-3.590268-0.318609$
H $\quad-1.650718-3.916923-0.882673$
H $\quad-3.420630-4.004744-0.818404$
C $\quad-2.463824-4.0699331 .118470$
H $\quad-1.536873-3.7645911 .618901$
H $\quad-2.482412-5.1677861 .107813$
H $\quad-3.319993-3.7312811 .717254$ 

C $\quad-1.356498-1.4669800 .046744$
H $\quad-1.276935-1.7427351 .102935$
H $\quad-1.460857-0.375308-0.014537$
$\mathrm{H} \quad-0.488816-1.807950-0.527787$
C $\quad-5.106578-2.127920-0.049095$
H $\quad-5.880512-1.5145050 .430746$
H $\quad-5.180769-3.1413510 .369750$
H $\quad-5.348556-2.173717-1.118997$
H $\quad-5.4873091 .627622-3.391472$
C $2.614937-3.515507-1.874944$
H $5.352278-2.3405191 .799196$
I $\quad-2.2177302 .1622020 .813494$
C $3.003836-2.924778-3.243296$
C $1.088919-3.723234-1.817376$
C $3.274649-4.892588-1.745736$
H $4.369222-4.829168-1.829839$
H $\quad 2.917670-5.542411-2.557956$
H $\quad 3.027067-5.377522-0.788749$
H $4.098914-2.846054-3.323454$
H $\quad 2.572599-1.925718-3.392622$
H $\quad 2.650144-3.582916-4.052862$
H $\quad 0.785544-4.048437-0.807704$
H $\quad 0.794140-4.506550-2.533841$
H $\quad 0.567589-2.792387-2.074665$
O $4.8823561 .478537-1.351668$
C $4.9939802 .559779-2.263492$
C $5.6609222 .005750-3.531471$
C $6.2996180 .709545-3.027432$
C $5.2716310 .272440-1.992108$
H $7.2662480 .911138-2.540138$
H $6.455582-0.033446-3.820562$
H $4.402374-0.196623-2.488411$
H $5.656942-0.415694-1.225779$
H $5.5964443 .352565-1.788478$
H $3.9928262 .966610-2.486768$
H $\quad 6.3796412 .708378-3.973505$
H $4.8914991 .773802-4.280617$ 


\section{$1 \mathbf{a}$}

H $\quad 1.057238-0.9566322 .031941$

C $0.493802-0.6100121 .164044$

C $\quad-0.890818-0.4649031 .240558$

H $\quad-1.411410-0.6992602 .170714$

C $-1.611709-0.0205270 .128952$

$\mathrm{H} \quad-2.6951110 .0929550 .191164$

C $\quad-0.9468440 .277108-1.056224$

H $\quad-1.4814770 .625535-1.941154$

C $0.4434240 .133583-1.140165$

C $1.1115370 .469749-2.445420$

C $1.160029-0.311743-0.023446$

H $\quad 2.243165-0.429219-0.073236$

O $\quad 0.4605150 .851662-3.388021$

C $2.6133490 .315848-2.538799$

H $3.1122840 .955234-1.796357$

H $2.9335240 .599725-3.547152$

H $\quad 2.907652-0.723423-2.333122$

\section{HBPin}

C $\quad-2.5692630 .745323-0.049755$

C $\quad-1.0072250 .7433400 .082293$

C $-3.0368300 .705602-1.502300$

C $\quad-3.2693421 .8663940 .698948$

O $\quad-2.926029-0.5179720 .542698$

C $\quad-0.2731801 .420032-1.062520$

O $\quad-0.703484-0.6644750 .077302$

C $\quad-0.5285771 .2966091 .422044$

B $-1.829381-1.3257850 .472661$

H $\quad-2.9370092 .8460220 .323931$

H $\quad-3.0723431 .8120761 .776178$

H $\quad-4.3539941 .7871350 .544915$

$\mathrm{H} \quad-2.8571731 .664351-2.008339$

H $\quad-4.1141960 .493144-1.519537$

H $\quad-2.520552-0.089700-2.058525$

H $\quad-0.4821890 .926191-2.019111$ 

H $\quad 0.8094501 .373661-0.882678$
H $\quad-0.5672882 .477716-1.135906$
H $\quad-0.6657622 .3852011 .480784$
H $\quad 0.5396671 .0681391 .535235$
H $\quad-1.0701780 .8268542 .255536$
H $\quad-1.852402-2.4936500 .731510$

\section{$2 \mathbf{a}$}

H $\quad 1.767624-1.945569-0.040863$

C $1.168570-1.033425-0.042728$

C $1.7936250 .214617-0.071276$

H $2.8825110 .282969-0.083212$

C $1.0159511 .369657-0.094514$

H $\quad 1.4943642 .350170-0.129880$

C $\quad-0.3775271 .280793-0.085696$

H $\quad-0.9856092 .184191-0.138873$

C $\quad-1.0114790 .037492-0.035869$

C $\quad-0.220948-1.119497-0.021318$

H $\quad-0.695553-2.103821-0.003269$

C $-2.531540-0.063271-0.012876$

O $\quad-3.1558141 .197060-0.057262$

C $\quad-3.031339-0.8645831 .186789$

H $\quad-2.848168-0.572019-0.938061$

H $\quad-2.720529-0.3688642 .120791$

H $\quad-2.625471-1.8846531 .200439$

H $\quad-4.127866-0.9212371 .162524$

H $\quad-3.0178871 .6233350 .797540$

\section{iPrOH}

H 1.9331331 .7808360 .557196

C $1.1047711 .365854-0.032129$

H $1.2817911 .606854-1.090698$

H 1.0942570 .2739530 .087562

C $\quad-0.2102401 .9760740 .415859$

$\mathrm{H} \quad-0.3720461 .7164371 .481124$

O $\quad-0.0758943 .3754310 .275094$

$\mathrm{H} \quad-0.9033693 .7857630 .547670$

C $-1.3898441 .456692-0.395951$ 


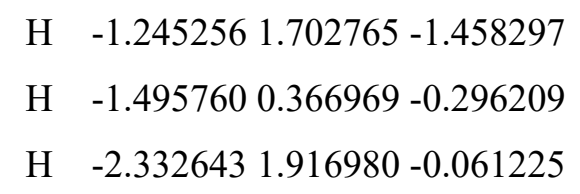

\section{iPrOBPin}

H $\quad-6.5989220 .7714254 .937163$

B $\quad-3.6569670 .4222352 .211011$

O $\quad-2.972615-0.6128422 .795174$

O $\quad-4.7568170 .8171352 .942112$

C $\quad-3.790982-1.0999443 .868051$

C -4.6683490 .1553094 .213460$

C $\quad-2.898613-1.5799154 .999488$

C $\quad-4.622685-2.2556973 .316906$

$\mathrm{H} \quad-2.330778-2.4599254 .668050$

H $\quad-2.182375-0.8043295 .296280$

H $\quad-3.500835-1.8660585 .874605$

C $-6.066812-0.1635884 .712920$

H $\quad-6.021296-0.7642525 .633482$

H $\quad-6.642555-0.7115773 .957481$

H $\quad-5.231014-2.7284714 .100591$

H $\quad-5.289071-1.9078372 .514340$

$\mathrm{H} \quad-3.941770-3.0075272 .895576$

C $\quad-3.9635701 .1129385 .171117$

H $\quad-4.5251042 .0569235 .201492$

$\mathrm{H} \quad-2.9424181 .3289064 .824100$

H $\quad-3.9094410 .7034396 .189466$

H $\quad-4.0892151 .307654-1.428963$

C $\quad-3.7574672 .226304-0.927074$

H $\quad-2.6838112 .358932-1.124201$

H $\quad-4.3027363 .079769-1.353221$

C $\quad-3.9994762 .1300310 .567274$

H $\quad-5.0750681 .9784800 .759522$

O $\quad-3.2889570 .9888731 .043121$

C $\quad-3.5366253 .3691261 .318147$

H $\quad-2.4578703 .5193641 .163833$

H $\quad-4.0708944 .2620120 .963986$

H $\quad-3.7310033 .2534132 .393687$

\section{2aOBPin}



H $\quad-6.6090340 .6690805 .133071$
B $\quad-3.6343330 .7070212 .414282$
O $\quad-3.013897-0.4543722 .792188$
O $\quad-4.7264611 .0097443 .201790$
C $-3.876351-1.0991583 .740263$
C $\quad-4.6974050 .1076234 .319632$
C $-3.029414-1.8381154 .761935$
C $\quad-4.756038-2.0774632 .964741$
H $\quad-2.498627-2.6636954 .268003$
H $\quad-2.280913-1.1736425 .210315$
$\mathrm{H} \quad-3.660555-2.2588625 .558976$
C $-6.122672-0.2276974 .724562$
H $\quad-6.134615-1.0103205 .497615$
H $\quad-6.707084-0.5692033 .861931$
H $\quad-5.411316-2.6522813 .633609$
H $\quad-5.379917-1.5438732 .233065$
H $\quad-4.108771-2.7766602 .418627$
C $\quad-3.9670610 .8167215 .457690$
H $\quad-4.4896191 .7564205 .685692$
$\mathrm{H} \quad-2.9339681 .0593335 .167820$
H $\quad-3.9451610 .2017456 .368164$
H $\quad-4.4525152 .082190-0.875572$
C $\quad-3.8730442 .891515-0.412332$
H $\quad-2.8531402 .847311-0.818169$
H $\quad-4.3259743 .855297-0.681783$
C $\quad-3.8592552 .7057251 .092892$
O $\quad-3.2272491 .4547281 .366224$
C $\quad-3.1521323 .8072101 .867108$
C -3.4866284 .0032493 .213521$
$\mathrm{H} \quad-4.2712183 .3854903 .655409$
C -2.8291364 .9639233 .979093$
H $\quad-3.1038905 .1064525 .025877$
C $\quad-1.8277945 .7482413 .405803$
H $\quad-1.3144336 .5053824 .000685$
C $\quad-1.4918205 .5646782 .065670$
H $\quad-0.7121736 .1767261 .609348$
C $\quad-2.1499044 .6001531 .301565$ 

H $\quad-1.8765394 .4730970 .253224$
H $\quad-4.8967262 .6586561 .461308$

\section{TSuncat}

C $\quad 2.265406-3.7679110 .910200$

H $\quad 3.199497-3.3753211 .337987$

H $\quad 1.878509-4.5520231 .574717$

H $\quad 2.482447-4.212199-0.069956$

C $1.242991-2.6522810 .786532$

C $\quad 0.987172-1.9588682 .109717$

O $1.760700-1.688465-0.172454$

H $\quad 0.193856-1.629384-1.691657$

B $\quad 0.754522-0.757444-0.866853$

O $\quad-0.225935-0.174509-0.03477$

O $1.4525120 .244991-1.575374$

C $0.0397621 .231745-0.015384$

C $0.7144901 .453495-1.411789$

C 1.0087701 .5245581 .130922

H $\quad 1.2115832 .6008871 .225860$

$\mathrm{H} \quad 0.5662501 .1728812 .073553$

H 1.9616260 .9972360 .973784

C $\quad-1.2668931 .9806300 .186627$

$\mathrm{H} \quad-1.6566811 .7774201 .194107$

H $\quad-1.1129043 .0658530 .088352$

$\mathrm{H} \quad-2.0221031 .658879-0.540955$

C $\quad 1.6711172 .633162-1.475384$

H $2.0741482 .724296-2.493815$

H $1.1541773 .571503-1.223221$

H $\quad 2.5143502 .490899-0.788734$

C $\quad-0.3196431 .547819-2.534990$

H $\quad-0.8729572 .497254-2.503802$

$\mathrm{H} \quad 0.2009401 .478818-3.500674$

$\mathrm{H} \quad-1.0392500 .717996-2.465515$

H $\quad 0.192379-1.2126212 .013244$

H $1.909369-1.4671952 .453595$

H $\quad 0.691510-2.7077922 .857862$

H $\quad 0.298977-3.0480100 .371982$

H $\quad-3.050741-6.375282-2.093980$ 

C $\quad-2.271567-5.621514-2.217469$
C $-2.603244-4.340994-2.666512$
H $\quad-3.641962-4.091148-2.888427$
C $\quad-1.611328-3.377676-2.824853$
H $\quad-1.880449-2.370899-3.151019$
C $\quad-0.277911-3.684045-2.529416$
C $0.839647-2.678127-2.688182$
C $0.048877-4.966008-2.077728$
H $\quad 1.094090-5.190629-1.861870$
C $\quad-0.944735-5.932676-1.924977$
H $\quad-0.681110-6.933233-1.577943$
C $\quad 0.816626-1.774190-3.897919$
H $2.083828-2.264824-1.028273$
O $1.965385-2.965820-2.183892$
H $\quad 1.168806-2.375968-4.750444$
H $1.509847-0.942019-3.728266$
H $\quad-0.183325-1.388424-4.127417$

\section{TS1}

Al $1.4448991 .527065-1.399167$

O $2.264107-0.034821-1.031498$

N $2.8589842 .482207-0.299201$

C 2.5078373 .8401450 .109611

$\mathrm{H} \quad 1.8257753 .7215730 .971074$

O $\quad-0.2286830 .923436-1.134772$

$\mathrm{N} \quad 0.6811873 .408501-1.365660$

C $1.6800644 .425613-1.044380$

H $2.3687644 .498389-1.907428$

C $1.1632455 .820919-0.718716$

H $\quad 0.4497165 .7577390 .121391$

H $0.6184546 .238538-1.578863$

N $\quad-2.380754-1.807631-0.819178$

C $2.3232476 .741480-0.340420$

H $1.9386847 .739080-0.085397$

H $2.9843856 .870633-1.214044$

C 3.1268346 .1644470 .822014

H 2.4831996 .1084841 .715762

H 3.9649526 .8281181 .078028 

C 3.6546054 .7657640 .499533
H $4.3787304 .819388-0.332742$
$\mathrm{H} \quad 4.1895624 .3686881 .374244$
C 3.9939231 .9667770 .010835
$\mathrm{H} \quad 4.7379622 .5864630 .529330$
C $4.3993990 .601619-0.214376$
C $3.465594-0.378703-0.653738$
C $3.871393-1.753289-0.654739$
C $5.193475-2.037943-0.331750$
H $5.528153-3.074336-0.353139$
C $6.132344-1.0594690 .040348$
C 5.7217050 .2504850 .126032
$\mathrm{H} \quad 6.4064351 .0330880 .462869$
C $\quad-0.5669593 .706152-1.522035$
$\mathrm{H} \quad-0.8798974 .758470-1.482378$
C $-1.6102912 .754453-1.768756$
C $\quad-1.3574581 .364880-1.615786$
C $\quad-2.3840720 .458656-1.995080$
C $\quad-3.6120610 .952117-2.412456$
H $\quad-4.3898490 .243773-2.710630$
C $\quad-3.8911502 .325327-2.468680$
C $-2.8870453 .214389-2.154171$
$\mathrm{H} \quad-3.0651034 .291190-2.208391$
C $\quad-2.053259-0.998274-2.062827$
H $\quad-2.582820-1.477902-2.894845$
H $\quad-0.974657-1.102763-2.248718$
C $\quad-3.865907-1.898108-0.583360$
H $\quad-4.223999-0.860672-0.493387$
$\mathrm{H} \quad-3.989011-2.3313960 .418408$
C $\quad-1.746366-3.152097-1.031020$
H $\quad-0.677503-2.946854-1.171957$
H $\quad-2.133773-3.530476-1.986310$
C $\quad-1.963421-4.1564930 .083681$
H $\quad-1.525512-3.8242121 .034595$
H $\quad-1.460078-5.090798-0.200382$
$\mathrm{H} \quad-3.025559-4.3880220 .242756$
C $-1.785034-1.1312560 .371126$ 

H $\quad-1.919887-1.7679271 .252585$
H $\quad-2.334063-0.1919490 .534491$
H $\quad-0.727356-0.9355830 .168449$
C $\quad-4.639810-2.688941-1.618089$
H $\quad-5.703817-2.618738-1.355760$
H $\quad-4.372346-3.755145-1.635358$
H $\quad-4.530018-2.285435-2.634043$
$\mathrm{H} \quad-4.8822612 .674262-2.753377$
C $2.861204-2.867929-0.948178$
H $7.154651-1.3469170 .285519$
I $\quad-4.7337631 .3419181 .230014$
C $\quad 2.278682-2.730239-2.363405$
C $1.742074-2.7864180 .105064$
C $3.502025-4.256190-0.834532$
H $4.308861-4.394966-1.569378$
H $2.736611-5.019644-1.036048$
H $3.907897-4.4447640 .170841$
H $\quad 3.079627-2.811437-3.115310$
H $\quad 1.751466-1.780305-2.527497$
H $\quad 1.570446-3.554580-2.552515$
H $\quad 2.159432-2.8674551 .120851$
H $\quad 1.037119-3.622726-0.031285$
O 0.9610151 .4924411 .436353
C $\quad-0.1242841 .4801731 .989765$
C -1.0841132 .6259861 .862564$
H $\quad-0.6051213 .4413111 .306378$
H -1.4082022 .9813662 .851445$
$\mathrm{H} \quad-2.0083152 .3037101 .343282$
C $\quad-0.5398910 .2851302 .791309$
C $\quad-1.8196690 .1821433 .348936$
$\mathrm{H} \quad-2.5573130 .9776463 .223114$
C $\quad-2.195764-0.9900244 .007739$
H $\quad-3.204709-1.0710964 .414937$
C $-1.295708-2.0488634 .120124$
H $\quad-1.592120-2.9635624 .637683$
C $\quad-0.011725-1.9443713 .570682$
H $\quad 0.690976-2.7747453 .660655$ 

C $0.364119-0.7809622 .908114$
H $1.350234-0.6755422 .451833$
H $\quad 1.199378-1.8346010 .024981$
O $2.4379492 .083062-2.997706$
C $1.8484582 .872389-4.071287$
C $2.8802442 .803265-5.180842$
C $3.3896621 .370499-5.045656$
C $3.4411021 .168607-3.539457$
H $\quad 4.3665251 .206073-5.517822$
H $2.6461640 .673764-5.454678$
H $3.1522150 .151924-3.252482$
H $4.4039701 .454241-3.089027$
H $\quad 1.6763223 .885413-3.689848$
H $\quad 0.9059092 .383599-4.352312$
H $3.6882503 .530691-5.005569$
H $2.4314213 .011198-6.160426$
Cl $0.5061400 .004156-3.902123$

\section{A}

Al $1.0790651 .082919-0.830929$

O $1.766825-0.542094-0.408872$

N $2.6844351 .993969-0.080765$

C 2.5014973 .4417290 .059754

H 1.8468043 .5880810 .940021

O $\quad-0.4467090 .450045-1.570841$

N $\quad 0.5788092 .966212-1.309359$

C $1.6938913 .901408-1.168825$

H $2.3479043 .741072-2.049305$

C $1.3449865 .381720-1.086047$

H $\quad 0.6561875 .544536-0.238294$

H $\quad 0.8205625 .703220-1.997705$

N $\quad-2.857890-1.889924-0.70988$

C $2.6107866 .218729-0.897277$

H $\quad 2.3423767 .280276-0.809174$

H $3.2424246 .127412-1.796804$

C 3.4027595 .7661720 .326214

$\mathrm{H} \quad 2.8055575 .9457141 .235841$

H 4.3198876 .3615330 .432160 

C 3.7599484 .2804740 .247248
H $4.4449924 .099982-0.600259$
$\mathrm{H} \quad 4.2883583 .9839101 .164642$
C 3.7514571 .3904580 .318830
H 4.5792701 .9864930 .726690
C $3.988000-0.0317650 .273815$
C $2.968685-0.956301-0.104453$
C $3.288096-2.349163-0.165972$
C $4.586005-2.7313210 .158509$
H $4.854327-3.7859000 .109230$
C $5.586217-1.8241630 .551091$
C $5.282022-0.4837660 .611128$
H $\quad 6.0379130 .2465780 .909947$
C $-0.6147363 .340848-1.620818$
H $\quad-0.8293794 .410651-1.749627$
C $-1.7290002 .456267-1.853913$
C $\quad-1.5871171 .039903-1.819321$
C $\quad-2.7281330 .245652-2.102983$
C $\quad-3.9326250 .858179-2.428418$
H $\quad-4.7995960 .234316-2.660735$
C $\quad-4.0758962 .248582-2.451028$
C $-2.9788353 .031470-2.154280$
H $\quad-3.0691014 .120183-2.152391$
C $\quad-2.593013-1.244742-2.064092$
H $\quad-3.287540-1.721044-2.766647$
H $\quad-1.566750-1.537493-2.322553$
C $\quad-4.270326-1.632607-0.236163$
H $\quad-4.359218-0.537497-0.133874$
$\mathrm{H} \quad-4.309438-2.0265130 .788232$
C $\quad-2.565541-3.356408-0.881656$
H $\quad-1.498663-3.408359-1.141976$
H $\quad-3.138232-3.692049-1.756660$
C $\quad-2.865717-4.2295780 .320924$
H $\quad-2.295591-3.9312141 .210378$
H $\quad-2.569034-5.2573330 .071736$
H $\quad-3.934291-4.2473220 .571971$
C $-1.939545-1.2998500 .315100$ 

H $\quad-2.060447-1.8561811 .251537$
$\mathrm{H} \quad-2.253016-0.2547010 .482612$
H $\quad-0.910239-1.363221-0.056474$
C $\quad-5.355602-2.251572-1.093036$
H $\quad-6.323415-1.965343-0.660295$
H $\quad-5.318523-3.350015-1.111166$
H $\quad-5.349219-1.886509-2.128877$
H $\quad-5.0389222 .700866-2.681454$
C $\quad 2.217417-3.377880-0.556388$
H $\quad 6.583300-2.1850960 .801083$
$\mathrm{Cl}-3.6429521 .5672260 .919086$
C $1.569902-3.024096-1.909800$
C $1.148761-3.4171170 .548650$
C $2.808528-4.786503-0.686929$
H $3.592132-4.830804-1.458000$
H $\quad 2.012525-5.487397-0.977155$
H $3.231678-5.1455820 .262159$
H $2.337995-2.947804-2.696114$
H $1.015819-2.076928-1.865353$
H $\quad 0.881740-3.831953-2.207272$
H $\quad 1.593870-3.7514671 .497935$
H $\quad 0.350815-4.1309360 .282959$
O $\quad 0.2368361 .3148200 .878529$
C $\quad-0.4766001 .5673051 .854706$
C $\quad-0.9511172 .9495232 .123451$
H $\quad-0.4111063 .6692641 .496962$
H $\quad-0.8730313 .2025073 .188249$
$\mathrm{H} \quad-2.0241252 .9386551 .831579$
C $\quad-0.8225360 .4566142 .766938$
C $\quad-1.9959290 .4883943 .532626$
H $\quad-2.6944401 .3183183 .421823$
C $\quad-2.312118-0.6039894 .337035$
H $\quad-3.235631-0.5973354 .916900$
C $-1.456197-1.7061534 .395516$
H $\quad-1.705974-2.5523185 .038393$
C $\quad-0.280705-1.7318353 .639263$
H $\quad 0.389273-2.5910423 .694995$ 

C $\quad 0.031413-0.6550152 .814705$
H $\quad 0.935098-0.6585202 .200281$
H $\quad 0.703102-2.4269750 .704797$
O $1.9393171 .009776-2.655827$
C $1.1482451 .146056-3.857697$
C $2.1815431 .332592-4.952105$
C $3.2873960 .384894-4.490003$
C $3.2803800 .574023-2.976408$
H $\quad 4.2682580 .603372-4.929067$
H $3.024429-0.652376-4.742874$
H $3.497158-0.350280-2.427110$
H $\quad 3.9749421 .361587-2.645017$
H $\quad 0.4643311 .991834-3.721016$
H $\quad 0.5559020 .228415-3.991157$
H $2.5398242 .373076-4.967468$
H $1.7853391 .089921-5.945546$

\section{A+HBPin}
Al $1.2373331 .179558-0.794171$
O $2.088763-0.386680-0.438768$
N $2.7516652 .219097-0.012504$
C 2.4470763 .6450410 .145165
H 1.7726613 .7291551 .018047
O $\quad-0.2108010 .450868-1.604521$
$\mathrm{N} \quad 0.5748743 .031786-1.225975$
C $1.6096624 .050562-1.083860$
H $2.2737523 .947143-1.964910$
C $1.1452375 .497479-0.988042$
H $0.4542865 .599675-0.132765$
H $\quad 0.5886995 .780447-1.893970$
N $\quad-2.216007-2.203366-0.699295$
C $2.3428066 .428687-0.798765$
H $1.9951117 .466882-0.708480$
H $2.9804596 .386710-1.697614$
C 3.1630796 .0338240 .426028
H 2.5492786 .1646281 .332896
H 4.0316996 .6969150 .538010
C 3.6330744 .5802160 .345885 

H $\quad 4.3362904 .455139-0.496611$
$\mathrm{H} \quad 4.1759314 .3224161 .266602$
C 3.8663611 .7050590 .379834
$\mathrm{H} \quad 4.6308432 .3613940 .817458$
C 4.2457710 .3164290 .272565
C $3.335119-0.687191-0.174131$
C $3.812397-2.024390-0.345541$
C $5.146017-2.280228-0.039228$
H $\quad 5.532975-3.289881-0.170216$
C $6.034694-1.3006760 .435672$
C $5.580948-0.0106290 .590175$
H $\quad 6.2491150 .7767920 .947306$
C $\quad-0.6647883 .307115-1.433399$
$\mathrm{H} \quad-0.9857944 .356070-1.502434$
C $-1.7088912 .323632-1.602022$
C $-1.4250440 .930116-1.681963$
C $\quad-2.5073420 .036291-1.887425$
C $\quad-3.8015770 .532692-1.999591$
H $\quad-4.625729-0.165429-2.164684$
C $\quad-4.0831541 .898800-1.899211$
C $\quad-3.0362182 .778501-1.703985$
H $\quad-3.2316983 .850351-1.621436$
C $-2.214994-1.428605-2.006626$
H $\quad-2.953372-1.922688-2.649992$
H $\quad-1.212900-1.578701-2.430024$
C $-3.555050-2.118830-0.005246$
H $\quad-3.719846-1.0520710 .207081$
$\mathrm{H} \quad-3.412805-2.5945340 .970912$
C $-1.835643-3.618606-1.040286$
H $\quad-0.810261-3.555344-1.432656$
H $\quad-2.490194-3.932229-1.864620$
C $\quad-1.914593-4.6060250 .108194$
H $\quad-1.282509-4.3164580 .957576$
H $\quad-1.551247-5.576930-0.254954$
H $\quad-2.942117-4.7497990 .466122$
C $\quad-1.204425-1.6184400 .236078$
H $\quad-1.161207-2.2405991 .136595$ 

H $\quad-1.546124-0.6125910 .520767$
H $\quad-0.234158-1.579092-0.270232$
C $\quad-4.714901-2.756516-0.739339$
H $\quad-5.596977-2.607902-0.101837$
H $\quad-4.591091-3.839009-0.885425$
H $\quad-4.926773-2.296087-1.713861$
H $\quad-5.1087122 .257603-1.971954$
C $2.872361-3.141043-0.821934$
H $7.065226-1.5653410 .670032$
$\mathrm{Cl} \quad-2.8790351 .1224161 .404866$
C $2.129118-2.742796-2.112765$
C $1.872374-3.4406670 .307206$
C $3.638192-4.434759-1.126557$
H $\quad 4.396090-4.284074-1.909607$
H $\quad 2.932069-5.197557-1.484964$
H $\quad 4.133672-4.842723-0.234368$
H $\quad 2.849913-2.484478-2.905571$
H $1.456962-1.888002-1.963103$
H $\quad 1.545002-3.603997-2.475531$
$\mathrm{H} \quad-4.8549682 .0999014 .942363$
H $\quad 2.398696-3.8580051 .178773$
H $1.129012-4.185269-0.024455$
O $\quad 0.3440711 .3178380 .877217$
C $\quad-0.2101491 .4340341 .981527$
C $\quad-0.5920162 .8030252 .457410$
H $\quad-0.9086793 .4082991 .600085$
H $\quad 0.3080433 .2432552 .922736$
H $\quad-1.3968142 .7739643 .195900$
C $\quad-0.1668040 .2942712 .928954$
C $\quad-1.0401710 .1976674 .019961$
$\mathrm{H} \quad-1.8653990 .9018824 .129868$
C $\quad-0.922615-0.8690334 .905470$
H $\quad-1.629181-0.9554805 .731717$
C $\quad 0.063885-1.8382154 .710874$
H $\quad 0.152360-2.6723945 .408956$
C $0.931930-1.7486513 .620529$
H $1.705461-2.5029773 .468733$ 

C $\quad 0.815156-0.6862132 .727878$
H $\quad 1.483290-0.5982581 .868913$
H $\quad-2.930181-1.7999273 .007500$
B $\quad-3.941266-1.1709243 .161906$
O $\quad-5.046426-1.3583142 .383410$
O $\quad-4.143296-0.3379294 .214359$
C $\quad-6.092753-0.4760572 .833663$
C $\quad-5.4726950 .2113664 .134093$
C $\quad-7.322254-1.3346103 .107855$
C $\quad-6.3878370 .4960681 .695300$
H $\quad-7.631500-1.8229712 .173050$
H $\quad-7.112757-2.1181633 .846005$
H $\quad-8.161172-0.7237113 .468469$
C $\quad-5.3380591 .7261334 .028003$
H $\quad-6.3235492 .2051433 .942143$
H $\quad-4.7144471 .9993283 .167513$
H $1.348459-2.5323950 .628241$
H $\quad-7.1723591 .2118941 .978298$
H $\quad-5.4798471 .0376701 .399766$
H $\quad-6.749465-0.0785790 .829015$
C $-6.185678-0.1542815 .431526$
H $\quad-5.6395870 .2951206 .272121$
H $\quad-6.209881-1.2400425 .586556$
H $\quad-7.2151620 .2291825 .443654$
O $2.1138531 .258152-2.621005$
C $1.3185211 .374643-3.822032$
C $\quad 2.3287261 .745202-4.890830$
C $3.5352080 .906776-4.471382$
C $3.4981921 .007453-2.949951$
H $4.4861531 .262371-4.886025$
H $3.395299-0.137543-4.785747$
H $3.8236340 .087697-2.449056$
H $4.0922561 .853376-2.569655$
H $\quad 0.5393602 .124158-3.641079$
H $\quad 0.8383870 .404421-4.017359$
H $2.5639232 .819113-4.840113$
H $\quad 1.9691901 .518464-5.901993$ 


\section{TS2}

Al $0.9927121 .116779-0.804375$

O $1.665994-0.489468-0.276046$

$\mathrm{N} \quad 2.3271552 .0989690 .314066$

C 2.1075183 .5483140 .357136

H 1.2676633 .7291881 .056353

O $\quad-0.2928050 .470995-1.915061$

$\mathrm{N} \quad 0.5517533 .002984-1.383283$

C $1.6007023 .955896-1.039699$

H $2.4350313 .765992-1.743648$

C $1.2427345 .434258-1.094523$

H $\quad 0.3953415 .628792-0.414161$

$\mathrm{H} \quad 0.9175465 .711164-2.108882$

$\mathrm{N} \quad-2.658015-1.976536-1.296860$

C $2.4444376 .283276-0.678133$

H $2.1743707 .347791-0.702516$

H $3.2567116 .147431-1.411386$

C 2.9427165 .8913910 .710679

H 2.1603796 .1167681 .454553

H 3.8201706 .4912570 .988907

C 3.2935424 .4043470 .788404

$\mathrm{H} \quad 4.1528704 .1804040 .131951$

H 3.5959344 .1584591 .816486

C 3.2156721 .5286331 .054780

$\mathrm{H} \quad 3.8470162 .1510011 .703030$

C 3.5098180 .1198051 .100019

C $2.746942-0.8441490 .373845$

C $3.198403-2.2018300 .363844$

C $4.304804-2.5227941 .147575$

H $4.659019-3.5527661 .161973$

C $5.005386-1.5882441 .926769$

C $4.612467-0.2698081 .886988$

H 5.1525330 .4923282 .453953

C $\quad-0.6001993 .351958-1.832842$

H $\quad-0.8323974 .416944-1.972690$

C $-1.6529342 .428379-2.196130$

C $-1.4414131 .020087-2.219714$ 

C $\quad-2.5272250 .192788-2.610922$
C $\quad-3.7411610 .764849-2.979590$
$\mathrm{H} \quad-4.5611040 .111481-3.289824$
C $-3.9475102 .146770-2.951882$
C $\quad-2.9024342 .962393-2.559468$
H $\quad-3.0399874 .045715-2.524439$
C $\quad-2.335039-1.292993-2.616415$
H $\quad-2.966119-1.772407-3.374640$
H $\quad-1.283616-1.535323-2.818701$
C $-4.111753-1.804420-0.915354$
H $\quad-4.278623-0.719831-0.862197$
$\mathrm{H} \quad-4.188123-2.1459710 .124818$
C $-2.285220-3.424530-1.457415$
$\mathrm{H} \quad-1.208736-3.426240-1.679836$
H $\quad-2.810659-3.787041-2.351138$
C $-2.583836-4.302316-0.257864$
H $\quad-2.047370-3.9756900 .642074$
H $\quad-2.247891-5.321308-0.492450$
H $\quad-3.656236-4.350174-0.028179$
C $\quad-1.837484-1.357309-0.211963$
H $\quad-2.077000-1.8494130 .736375$
H $\quad-2.129113-0.304573-0.125125$
H $\quad-0.781730-1.435635-0.491917$
C $\quad-5.099726-2.503389-1.826054$
H $\quad-6.108549-2.252466-1.471494$
H $\quad-5.009336-3.598096-1.799355$
H $\quad-5.037160-2.174680-2.873026$
H $\quad-4.9128082 .568352-3.227462$
C $2.475855-3.279944-0.457519$
H $\quad 5.858052-1.9048592 .526428$
Cl -3.8588511 .3687180 .564016$
C $2.265906-2.824631-1.914502$
C $\quad 1.125475-3.5840440 .208569$
C $3.276399-4.588141-0.506072$
H $\quad 4.279908-4.435302-0.930072$
H $\quad 2.748145-5.311390-1.143447$
H $\quad 3.383937-5.0470150 .486950$ 

H $\quad 3.237025-2.606300-2.387519$
H $1.631411-1.931879-1.982705$
H $\quad 1.798750-3.639732-2.489096$
H $\quad-4.9265401 .2823605 .726277$
H $\quad 1.277684-3.9888181 .220415$
H $\quad 0.572454-4.340163-0.372747$
O $\quad-0.3080291 .4169070 .582658$
C $\quad-0.4904291 .5528501 .809363$
C $\quad-1.2970112 .7101692 .302685$
$\mathrm{H} \quad-2.0326662 .9784401 .535334$
$\mathrm{H} \quad-0.6105763 .5575962 .474424$
$\mathrm{H} \quad-1.8156202 .4632073 .237754$
C $\quad 0.3547410 .7766802 .761700$
C 0.9962881 .4319553 .820039
H $\quad 0.8123472 .4922044 .004073$
C $\quad 1.8823870 .7297024 .637829$
H 2.3904651 .2441735 .454772
C $2.099505-0.6310464 .425374$
H $2.783722-1.1820595 .072255$
C $1.430596-1.2943803 .394001$
H $\quad 1.590986-2.3618673 .235579$
C $\quad 0.570498-0.5903232 .559105$
H $\quad 0.046052-1.0891041 .743709$
H $\quad-1.9932340 .3474371 .976602$
B $\quad-3.2279420 .3214272 .155680$
O $\quad-3.729046-1.0226852 .130514$
O $\quad-3.6793720 .9489383 .344448$
C $\quad-4.748848-1.1055163 .126615$
C $\quad-4.257138-0.0517274 .174303$
C $\quad-4.815743-2.5328713 .647513$
C $\quad-6.082683-0.7048472 .494056$
H $\quad-5.197089-3.1996182 .859122$
H $\quad-3.822859-2.8896193 .949859$
H $\quad-5.496617-2.6063524 .508664$
C $\quad-5.3627580 .5683025 .013636$
H $\quad-5.903108-0.2017595 .584911$
H $\quad-6.0748081 .1123694 .381281$ 

H $\quad 0.516477-2.6758930 .287503$
H $\quad-6.918006-0.8168183 .199968$
H $\quad-6.0448250 .3334822 .136271$
H $\quad-6.274962-1.3580471 .629036$
C $\quad-3.156245-0.6162085 .075479$
H $\quad-2.6969040 .2158855 .627909$
H $\quad-2.374738-1.1008034 .470747$
H $\quad-3.547416-1.3432615 .801635$
O $2.2599671 .127517-2.366750$
C $1.7896351 .254857-3.727958$
C $3.0575271 .472564-4.532960$
C $4.0489300 .575943-3.792539$
C $3.6653430 .796055-2.334869$
H $\quad 5.0991250 .824647-3.987429$
H $\quad 3.888078-0.475763-4.071003$
H $3.805138-0.093316-1.708588$
H $4.2019751 .645061-1.882183$
H $\quad 1.0724032 .083943-3.763115$
H $1.2710660 .324885-4.001985$
H $3.3718622 .525900-4.478445$
H $2.9314411 .205060-5.589040$
B

Al $0.9187791 .002446-0.713525$

O $1.632842-0.640705-0.313830$

N 2.3273981 .9300610 .357892

C 2.1044963 .3702550 .462389

H 1.2461843 .5002961 .146044

O $\quad-0.2236830 .407856-2.043448$

N $\quad 0.5831752 .924051-1.341246$

C $1.6295033 .849026-0.924720$

H $2.4768623 .685902-1.619672$

C $1.2738835 .329551-0.913580$

H $\quad 0.4013605 .484156-0.254692$

H $\quad 0.9846965 .660983-1.922520$

$\mathrm{N} \quad-2.589285-2.016359-1.44172$

C $2.4553106 .158692-0.409655$

H $2.1816277 .222638-0.387939$ 

H $3.2946426 .063514-1.118794$
C 2.9059905 .6950140 .972865
$\mathrm{H} \quad 2.0938065 .8712051 .697948$
H 3.7662126 .2868271 .315221
C 3.2678424 .2091040 .977957
H 4.1534754 .0323740 .341795
H 3.5336303 .9023922 .000259
C 3.2507501 .3336111 .025875
H 3.9227411 .9271061 .660313
C $3.531490-0.0815411 .011276$
C $2.714073-1.0202910 .311059$
C $3.123813-2.3937650 .292732$
C $4.265628-2.7463311 .006597$
H $\quad 4.590840-3.7860101 .003935$
C $5.038054-1.8288691 .736960$
C $4.667914-0.5030111 .728457$
H 5.2513070 .2424862 .274578
C $\quad-0.5311243 .296710-1.847738$
H $\quad-0.7511894 .365702-1.982602$
C $-1.5724052 .379368-2.285182$
C $\quad-1.3564180 .969049-2.339754$
C $\quad-2.4467260 .152942-2.758372$
C $-3.6476990 .730287-3.163002$
$\mathrm{H} \quad-4.4601000 .084266-3.508428$
C $-3.8419762 .113806-3.135165$
C $\quad-2.8032882 .918605-2.691073$
$\mathrm{H} \quad-2.9373054 .002581-2.650210$
C $\quad-2.239660-1.328920-2.760009$
H $\quad-2.842736-1.824457-3.530155$
H $\quad-1.179027-1.555762-2.927659$
C $\quad-4.060629-1.901222-1.138181$
H $\quad-4.272618-0.824601-1.120603$
H $\quad-4.184385-2.250409-0.105498$
C $\quad-2.147473-3.449104-1.575404$
H $\quad-1.058003-3.404733-1.713057$
H $\quad-2.587642-3.828036-2.507523$
C $\quad-2.500785-4.345083-0.404562$ 

H $\quad-2.040612-4.0065710 .532907$
H $\quad-2.105634-5.347832-0.616339$
H $\quad-3.584672-4.443616-0.257902$
C $-1.843117-1.358654-0.323490$
$\mathrm{H} \quad-2.095790-1.8686600 .612066$
H $\quad-2.151517-0.309969-0.251618$
H $\quad-0.770899-1.392816-0.543762$
C $\quad-4.979700-2.636922-2.092956$
H $\quad-6.013652-2.446728-1.775496$
H $\quad-4.829209-3.724806-2.078561$
H $\quad-4.893071-2.285617-3.129974$
$\mathrm{H} \quad-4.7887592 .548284-3.452966$
C $2.304209-3.454099-0.456352$
H $5.918474-2.1653922 .283246$
$\mathrm{Cl} \quad-4.1279681 .4607000 .286347$
C $2.013538-3.026908-1.908317$
C $\quad 0.988202-3.6751840 .305529$
C $3.036284-4.801035-0.519159$
H $4.014859-4.708936-1.013402$
H $2.432374-5.514989-1.097822$
H $3.190646-5.2365920 .478172$
H $\quad 2.956368-2.849172-2.450211$
H $1.410759-2.110991-1.956168$
H $1.485812-3.841235-2.431759$
H $\quad-5.2746311 .4246515 .556424$
H $\quad 1.190322-4.0259281 .328958$
H $\quad 0.379645-4.444494-0.198412$
O $\quad-0.4232071 .1546080 .455114$
C $\quad-0.7893321 .2296511 .780714$
C $\quad-1.3042612 .6230462 .137775$
H $\quad-2.0962302 .8985291 .429452$
H $\quad-0.5091433 .3788922 .058138$
H $\quad-1.7145932 .6640413 .157050$
C $\quad 0.3059160 .7179582 .717287$
C $\quad 1.0632501 .5433023 .553928$
$\mathrm{H} \quad 0.8536172 .6140733 .601505$
C 2.0834471 .0112924 .349280 

H 2.6607461 .6696415 .001652
C $2.352307-0.3560134 .327541$
H $3.147356-0.7709594 .948892$
C $1.595860-1.1930003 .504653$
H $1.805469-2.2644393 .474610$
C $0.586736-0.6550172 .710059$
H $\quad 0.003515-1.3044222 .050658$
H $\quad-1.6430120 .5269701 .937236$
B $\quad-4.1743030 .6149961 .838853$
O $\quad-3.982681-0.7312141 .926179$
O $\quad-4.4309211 .2288533 .009859$
C $\quad-4.335543-1.1197933 .278786$
C $\quad-4.2728220 .2485204 .065957$
C $\quad-3.339541-2.1635803 .753250$
C $\quad-5.740917-1.7066103 .207561$
H $\quad-3.447177-3.0756193 .148328$
$\mathrm{H} \quad-2.306635-1.8021953 .664258$
$\mathrm{H} \quad-3.530376-2.4302794 .802622$
C $\quad-5.3937540 .4461095 .072602$
H $\quad-5.353335-0.3299185 .850456$
$\mathrm{H} \quad-6.3792390 .4204364 .593512$
H $\quad 0.416919-2.7404980 .368333$
H $\quad-6.081688-2.0519394 .192753$
H $\quad-6.460359-0.9678732 .827202$
H $\quad-5.736090-2.5664052 .523012$
C $\quad-2.9256980 .5041704 .731917$
H $\quad-2.9071281 .5381595 .102603$
$\mathrm{H} \quad-2.0865480 .3733794 .035284$
H $\quad-2.775307-0.1711865 .584917$
O $2.3137181 .083479-2.317604$
C $\quad 1.8924141 .275475-3.678937$
C $3.1790331 .582669-4.423814$
C $4.1595270 .644302-3.722897$
C $3.7061770 .722715-2.267535$
H $\quad 5.2113600 .929571-3.846854$
H $\quad 4.036686-0.379844-4.104569$
H $\quad 3.813375-0.229231-1.7333355$ 


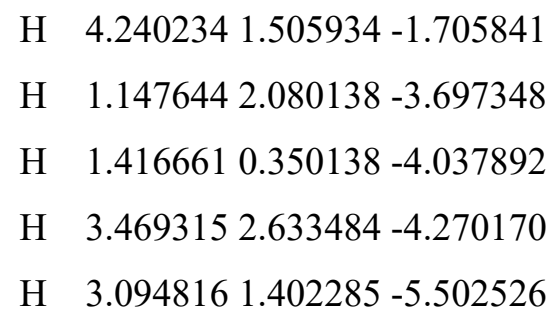

\section{B+iPrOH}

Al $0.8625830 .862061-0.292534$

O $1.823100-0.635939-0.029033$

$\mathrm{N} \quad 2.1112071 .8901060 .867951$

C $\quad 1.6753593 .2782561 .000342$

H $\quad 0.7217723 .2507981 .560741$

O $\quad-0.0570580 .138226-1.702644$

N $\quad 0.4666052 .724060-1.015459$

C $1.3299083 .753168-0.424319$

H $2.2739003 .718182-1.001899$

C $0.7930515 .181141-0.432718$

H $\quad-0.1906285 .1979790 .066792$

H $\quad 0.6418805 .531494-1.463958$

N $\quad-2.717410-2.112164-1.659393$

C 1.7610156 .1252110 .282356

H 1.3439917 .1418200 .293982

H $2.7032296 .177994-0.288641$

C 2.0588585 .6518951 .702201

$\mathrm{H} \quad 1.1300185 .6686232 .296751$

H 2.7616126 .3372272 .195417

C 2.6303354 .2337801 .701042

H 3.6050474 .2238821 .181525

H 2.8075473 .8998672 .734494

C 3.1349241 .4022541 .483360

H 3.7237312 .0549202 .144276

C 3.6155640 .0463301 .369275

C $2.951980-0.9127560 .547803$

C $3.560519-2.1893720 .332008$

C $4.719756-2.4791021 .039244$

H $5.193553-3.4514800 .905140$

C $5.332840-1.5653281 .920413$

C $4.794113-0.3059672 .062441$ 

H $\quad 5.2752360 .4366652 .703989$
C $\quad-0.3916152 .999181-1.929612$
$\mathrm{H} \quad-0.5555774 .045754-2.225279$
C $-1.1760122 .019159-2.660489$
C $\quad-0.9796370 .622796-2.467013$
C $\quad-1.848871-0.276271-3.155302$
C $\quad-2.7607670 .210812-4.083005$
H $\quad-3.391838-0.494710-4.631154$
C $\quad-2.8963591 .585078-4.330132$
C $\quad-2.1183692 .469687-3.604488$
H $\quad-2.2349123 .546024-3.756466$
C $-1.755832-1.723598-2.780861$
H $\quad-1.974079-2.391347-3.622144$
H $\quad-0.751371-1.940690-2.394909$
C $\quad-4.139128-2.158696-2.152008$
H $\quad-4.363806-1.142838-2.503195$
H $\quad-4.759588-2.315979-1.261220$
C $\quad-2.258596-3.445957-1.122585$
H - $1.283646-3.248047-0.655131$
H $\quad-2.087636-4.094167-1.993351$
C $\quad-3.205219-4.101205-0.134709$
$\mathrm{H} \quad-3.436045-3.4555140 .724037$
$\mathrm{H} \quad-2.710922-5.0019240 .253039$
H $\quad-4.148507-4.418283-0.598792$
C $-2.655082-1.097806-0.560931$
H $\quad-3.281463-1.4348530 .270981$
H $\quad-3.058650-0.147017-0.922355$
H $\quad-1.612758-0.966567-0.247940$
C $\quad-4.428273-3.195490-3.219482$
H $\quad-5.504060-3.161633-3.436762$
H $\quad-4.194887-4.218175-2.893098$
H $\quad-3.904181-3.000834-4.164727$
H $\quad-3.6109401 .947118-5.067858$
C $2.958680-3.145832-0.705334$
H $\quad 6.239677-1.8479662 .454067$
Cl $\quad-5.8154650 .013958-0.018135$
C $2.947553-2.448336-2.080428$ 

C $\quad 1.527828-3.553974-0.311883$
C $3.788748-4.426801-0.837522$
H $4.819975-4.215931-1.157936$
H $\quad 3.331473-5.079782-1.594879$
H $3.825098-4.9877510 .108138$
H $3.975430-2.197881-2.388953$
H $\quad 2.344254-1.530138-2.058188$
H $\quad 2.528528-3.128361-2.838916$
H $\quad-6.4879061 .9199174 .968161$
H $1.538239-4.1417560 .616424$
H $\quad 1.095680-4.182413-1.109064$
O $\quad-0.5212240 .8329760 .863506$
C $\quad-0.7832430 .3501312 .157959$
C $\quad-0.4019381 .3819373 .217199$
H $\quad-0.9177352 .3287213 .004375$
H $\quad 0.6817271 .5745983 .216913$
$\mathrm{H} \quad-0.6879041 .0455384 .225253$
C $\quad-0.200180-1.0265112 .470008$
C $1.081067-1.1967643 .000218$
H $1.714944-0.3284633 .182343$
C $1.568027-2.4640703 .322303$
H $\quad 2.578335-2.5682143 .723454$
C $0.761360-3.5876763 .147746$
H $1.132086-4.5776553 .419028$
C $\quad-0.528247-3.4348752 .637432$
H $\quad-1.176633-4.3066692 .523504$
C $\quad-0.998169-2.1659882 .299266$
H $\quad-2.027154-2.0347431 .954409$
H $\quad-1.8786770 .2088612 .222066$
B $\quad-5.2500600 .0541641 .665430$
O $-4.477453-0.9252852 .221140$
O $\quad-5.7566550 .9461192 .544535$
C $\quad-4.723910-0.8476413 .654827$
C $\quad-5.1772380 .6457733 .836012$
C $-3.468813-1.2145274 .422056$
C $\quad-5.841265-1.8433703 .950226$
H $\quad-3.215841-2.2706924 .255275$ 

H $\quad-2.609233-0.6070354 .115485$
H $\quad-3.637669-1.0696325 .499406$
C $\quad-6.2360970 .8528524 .904853$
$\mathrm{H} \quad-5.8589410 .5293035 .886060$
H $\quad-7.1539310 .2992324 .674557$
H $\quad 0.891161-2.672687-0.151049$
H $\quad-6.061356-1.8915745 .024966$
H $\quad-6.763531-1.5746293 .415098$
$\mathrm{H} \quad-5.524895-2.8404373 .614568$
C $\quad-4.0093021 .6020314 .043285$
$\mathrm{H} \quad-4.3862712 .6328503 .977481$
H $\quad-3.2506221 .4601183 .261792$
$\mathrm{H} \quad-3.5509821 .4617935 .032192$
H $\quad-4.6904382 .526257-1.114272$
C $-4.0294633 .281091-0.666232$
H $\quad-3.1160543 .347979-1.275117$
H $\quad-4.5371674 .255967-0.694358$
C -3.6807022 .8874620 .761641$
$\mathrm{H} \quad-4.6045832 .9037641 .363568$
O $\quad-3.2176731 .5498100 .824713$
$\mathrm{H} \quad-2.2528761 .4940540 .648456$
C $\quad-2.6608053 .8361001 .376872$
H $\quad-1.6823613 .6821990 .888158$
H $\quad-2.9586304 .8855671 .240524$
H $\quad-2.5397313 .6488992 .453022$
O $2.5160221 .203080-1.950340$
C $2.1716181 .211306-3.338385$
C $3.4129111 .740480-4.036652$
C $4.5165701 .076368-3.216570$
C $3.9409381 .102230-1.800128$
H $5.4863471 .584494-3.283730$
H $4.6536790 .036915-3.548280$
H $4.1892890 .193594-1.236962$
H $4.2855011 .977023-1.223470$
H $\quad 1.2837601 .839302-3.476992$
$\mathrm{H} \quad 1.9253160 .185866-3.661811$
H $\quad 3.4622142 .836168-3.942911$ 
H $3.4438551 .483403-5.102811$

\section{TS3}

Al 1.0137011 .0441890 .148172

O $2.055728-0.3894530 .439443$

$\mathrm{N} \quad 2.2694762 .1843881 .183113$

C 1.7902043 .5617891 .246271

H $\quad 0.8484863 .5370971 .825784$

O $\quad 0.1807090 .214168-1.251972$

N $0.5830292 .839493-0.715166$

C $1.4122263 .936483-0.199706$

H $2.3512903 .899877-0.784700$

C $0.8192825 .339489-0.287312$

H $\quad-0.1617575 .3466720 .216940$

H $\quad 0.6495175 .623426-1.335965$

N $\quad-2.237841-2.247257-1.140464$

C 1.7526636 .3614610 .364561

H $\quad 1.2914437 .3580140 .326307$

H $2.6857936 .424177-0.220026$

C 2.0862845 .9801331 .804486

H 1.1641105 .9880102 .409519

H 2.7629876 .7214032 .251010

C 2.7202624 .5907031 .870814

H 3.6822974 .5953901 .328380

$\mathrm{H} \quad 2.9351404 .3203052 .916065$

C 3.3752251 .7917191 .719378

H 3.9809532 .5140432 .285235

C 3.9326050 .4664431 .612041

C $3.261226-0.5639060 .889545$

C $3.943006-1.7951480 .635857$

C $\quad 5.200255-1.9652941 .201539$

H $\quad 5.736070-2.8990501 .031257$

C $5.835735-0.9780761 .981001$

C 5.2108390 .2348502 .165039

H 5.7002651 .0347302 .726532

C $\quad-0.2719083 .025478-1.655193$

H $\quad-0.4568004 .043547-2.027368$

C $\quad-1.0245281 .976008-2.318417$ 

C $\quad-0.7579750 .605018-2.050910$
C $-1.563393-0.375631-2.701245$
C $\quad-2.5104400 .014992-3.639909$
H $\quad-3.099332-0.750346-4.153505$
C $\quad-2.7326231 .366115-3.942457$
C $\quad-1.9975602 .328307-3.272242$
H $\quad-2.1740463 .387652-3.476465$
C $-1.350851-1.802924-2.300682$
H $\quad-1.549142-2.498812-3.123958$
H $\quad-0.319552-1.939216-1.949223$
C $-3.682934-2.321435-1.558179$
H $\quad-3.947054-1.309373-1.889999$
H $\quad-4.254657-2.494929-0.638062$
C $\quad-1.713242-3.582277-0.674787$
H $\quad-0.702104-3.378727-0.298102$
H $\quad-1.617682-4.211191-1.570418$
C $\quad-2.550423-4.2673840 .387533$
H $\quad-2.665362-3.6517111 .289496$
H $\quad-2.026136-5.1857340 .683799$
H $\quad-3.545388-4.5574290 .024810$
C $-2.137200-1.265333-0.015977$
$\mathrm{H} \quad-2.781080-1.5982170 .803941$
H $\quad-2.500849-0.290173-0.358034$
H $\quad-1.090521-1.1877710 .297634$
C $\quad-4.004405-3.361602-2.612559$
H $\quad-5.083590-3.314079-2.809167$
H $\quad-3.779001-4.385107-2.283422$
H $\quad-3.495822-3.180829-3.569153$
$\mathrm{H} \quad-3.4767861 .650115-4.685115$
C $3.303064-2.840805-0.285610$
H $\quad 6.820824-1.1694622 .405453$
Cl $\quad-5.2533590 .0983020 .252192$
C $3.021535-2.204135-1.660986$
C $1.995404-3.3686030 .328156$
C $4.231932-4.039185-0.506822$
H $\quad 5.181759-3.739077-0.973949$
H $\quad 3.743023-4.759570-1.178350$ 

H $\quad 4.456483-4.5619430 .434673$
H $3.959810-1.848284-2.116937$
H $2.323951-1.359913-1.577694$
H $\quad 2.590779-2.959978-2.337601$
H $\quad-6.3892912 .1537245 .060563$
H $\quad 2.199986-3.9063141 .264598$
H $\quad 1.524665-4.078417-0.373169$
O $\quad-0.3547531 .0148131 .313026$
C $\quad-0.5228440 .5978382 .652382$
C $\quad-0.0979561 .6901823 .630752$
$\mathrm{H} \quad-0.6425922 .6173023 .406093$
H $\quad 0.9797581 .9001903 .558504$
$\mathrm{H} \quad-0.3184811 .3976704 .668259$
C $0.116549-0.7459332 .992351$
C $1.443904-0.8571303 .415618$
H 2.0695780 .0335623 .486028
C $1.988675-2.0916443 .766490$
H $3.031080-2.1512594 .086137$
C $1.199574-3.2411503 .722533$
H $\quad 1.618170-4.2058814 .014980$
C $\quad-0.130636-3.1474703 .313987$
H $\quad-0.760522-4.0397523 .301327$
C $\quad-0.663594-1.9090082 .952401$
H $\quad-1.719013-1.8171252 .683144$
H $\quad-1.6070010 .4370212 .789942$
В $\quad-4.6543970 .3563081 .929694$
O $\quad-3.931087-0.6049602 .600429$
O $\quad-5.3370571 .2015152 .748236$
C $\quad-4.387820-0.5498733 .978528$
C $\quad-4.9097490 .9252324 .097667$
C $\quad-3.252519-0.8839314 .928392$
C $-5.507319-1.5794264 .104001$
H $\quad-2.957604-1.9365534 .818004$
H $\quad-2.367238-0.2615114 .747944$
H $\quad-3.583627-0.7325725 .966658$
C $\quad-6.0985881 .0950515 .027893$
H $\quad-5.8375890 .7785056 .048484$ 


$$
\begin{aligned}
& \text { H } \quad-6.9624680 .5151034 .682896 \\
& \text { H } \quad 1.296511-2.5498830 .555058 \\
& \text { H } \quad-5.880065-1.6465255 .134975 \\
& \text { H } \quad-6.347502-1.3293933 .440141 \\
& \text { H } \quad-5.115765-2.5636363 .811577 \\
& \text { C }-3.8071821 .9156584 .459771 \\
& \text { H } \quad-4.1956832 .9359114 .327710 \\
& \text { H } \quad-2.9356371 .7874403 .804254 \\
& \text { H } \quad-3.4940941 .7978385 .506440 \\
& \text { H } \quad-4.3790732 .650517-0.725737 \\
& \text { C }-3.7053293 .401469-0.292330 \\
& \text { H } \quad-2.7713653 .406348-0.871814 \\
& \text { H } \quad-4.1726024 .392506-0.382985 \\
& \text { C }-3.4155613 .0769711 .164931 \\
& \text { H } \quad-4.3491503 .1724041 .740703 \\
& \text { O } \quad-3.0267461 .7186551 .327243 \\
& \text { H } \quad-2.0691141 .5728771 .133942 \\
& \text { C } \quad-2.3599524 .0040441 .749552 \\
& \text { H } \quad-1.3808113 .7694351 .297866 \\
& \text { H } \quad-2.6013245 .0555531 .537273 \\
& \text { H } \quad-2.2777923 .8819852 .838315 \\
& \text { O } 2.7813521 .391884-1.653812 \\
& \text { C } 2.3915181 .296644-3.022415 \\
& \text { C } 3.5494661 .905154-3.797412 \\
& \text { C } 4.7419621 .391910-2.992995 \\
& \text { C } 4.2115261 .416417-1.556680 \\
& \text { H } 5.6508561 .993912-3.115747 \\
& \text { H } 4.9778010 .359976-3.291208 \\
& \text { H } 4.5595540 .553192-0.973167 \\
& \text { H } \quad 4.5023742 .335718-1.019352 \\
& \text { H } \quad 1.4420231 .829108-3.157033 \\
& \text { H } 2.2339250 .237793-3.292600 \\
& \text { H } 3.4953643 .003933-3.756710 \\
& \text { H } 3.5670911 .599600-4.851134
\end{aligned}
$$

\section{TS4}
Al 0.9461191 .0161760 .188746
O $1.965436-0.4456420 .408556$ 

N $\quad 2.2422132 .0885341 .245077$
C 1.8303053 .4865901 .318486
$\mathrm{H} \quad 0.8861703 .5075511 .896716$
O $\quad 0.1525230 .238939-1.260856$
$\mathrm{N} \quad 0.6438662 .830528-0.690061$
C $1.4829963 .897104-0.124530$
H $2.4317853 .861764-0.693806$
C $\quad 0.9137055 .312032-0.169956$
H $\quad-0.0533405 .3245370 .362309$
H $\quad 0.7222045 .626910-1.205505$
N $\quad-2.321144-2.152961-1.33356$
C 1.8906436 .2977820 .475148
$\mathrm{H} \quad 1.4556777 .3068310 .466491$
H $2.8087766 .345353-0.134175$
C 2.2544065 .8874791 .899963
H 1.3579305 .9472212 .537506
H 2.9854636 .5882712 .325963
C 2.8130354 .4648641 .946733
H 3.7690764 .4252971 .395277
H 3.0239504 .1750112 .987506
C 3.3440401 .6501731 .755019
H 3.9807412 .3424622 .323946
C 3.8629390 .3150941 .608551
C $3.168334-0.6666190 .843424$
C $3.825054-1.8980960 .529878$
C $5.076398-2.1218951 .089339$
H $\quad 5.592358-3.0579120 .876145$
C $5.732014-1.1860081 .914947$
C 5.1355890 .0317692 .150868
H 5.6427460 .7960132 .745257
C $-0.1047533 .052219-1.711239$
H $\quad-0.1931404 .075539-2.103731$
C $\quad-0.8580202 .045760-2.435678$
C $\quad-0.6970750 .666439-2.135056$
C $\quad-1.503444-0.278370-2.834447$
C $\quad-2.3597180 .155648-3.839716$
H $\quad-2.951602-0.580406-4.391219$ 

C $\quad-2.4803311 .514269-4.168167$
C $\quad-1.7360382 .442776-3.459977$
$\mathrm{H} \quad-1.8340083 .507549-3.687443$
C $\quad-1.363121-1.717064-2.436908$
H $\quad-1.536261-2.395074-3.280631$
H $\quad-0.355670-1.889647-2.034256$
C $\quad-3.743887-2.181318-1.826652$
H $\quad-3.966711-1.154843-2.147351$
H $\quad-4.365320-2.363067-0.941776$
C $-1.858793-3.508682-0.859028$
H $\quad-0.868111-3.335566-0.417477$
H $\quad-1.722773-4.126179-1.757548$
C $\quad-2.777157-4.1891090 .137571$
$\mathrm{H} \quad-2.942043-3.5839541 .039550$
$\mathrm{H} \quad-2.291939-5.1224420 .452976$
H $\quad-3.751424-4.454187-0.294046$
C $\quad-2.252308-1.193196-0.188988$
H $\quad-2.917291-1.5411660 .607387$
H $\quad-2.605580-0.212364-0.524507$
H $\quad-1.215506-1.1236490 .156445$
C $-4.034189-3.187953-2.921931$
H $\quad-5.101964-3.115083-3.167299$
H $\quad-3.843552-4.222948-2.607174$
H $\quad-3.477859-2.994795-3.848993$
H $\quad-3.1517031 .830785-4.965197$
C $3.170351-2.881135-0.448258$
H $6.711403-1.4189612 .331756$
Cl $-5.434511-0.1493370 .331271$
C $2.913082-2.164357-1.787912$
C $1.844898-3.4110890 .123265$
C $4.075777-4.085560-0.725431$
H $\quad 5.034750-3.781902-1.171076$
H $3.576576-4.760072-1.435962$
H $4.283063-4.6604060 .189367$
H $3.860533-1.796295-2.214480$
H $2.228318-1.315191-1.661139$
H $\quad 2.477546-2.874106-2.510152$ 

H $\quad-6.4115021 .8841025 .167254$
H $\quad 2.025876-4.0091851 .027369$
H $\quad 1.362558-4.064616-0.623583$
O $\quad-0.4481421 .0024541 .320065$
C $\quad-0.6074870 .5277702 .646145$
C $\quad-0.1583921 .5646703 .673164$
H $\quad-0.7249332 .4972293 .545375$
H $\quad 0.9132651 .7925663 .570164$
H $\quad-0.3289401 .1968964 .696028$
C $\quad 0.020465-0.8386982 .909885$
C $1.337766-0.9812923 .353883$
H $1.964161-0.0992693 .494695$
C $1.872021-2.2380283 .635853$
H $2.907136-2.3222023 .973150$
C $1.081113-3.3789173 .501972$
H $1.490862-4.3616293 .742214$
C $\quad-0.239295-3.2542143 .070067$
H $\quad-0.871562-4.1411032 .985717$
C $\quad-0.761485-1.9938152 .775832$
H $\quad-1.811620-1.8820302 .494509$
H $\quad-1.6913020 .3691992 .787071$
B $\quad-4.7349140 .1373941 .975714$
O $\quad-3.972443-0.8127932 .617267$
O $\quad-5.4120610 .9657222 .817899$
C $\quad-4.390050-0.7720854 .009625$
C $\quad-4.9361870 .6934514 .153282$
C $\quad-3.220036-1.0907314 .921307$
C $\quad-5.485733-1.8236904 .161082$
$\mathrm{H} \quad-2.899530-2.1326394 .783049$
H $\quad-2.358246-0.4405914 .727239$
H $\quad-3.525929-0.9649165 .970640$
C -6.1023090 .8313165 .117612$
H $\quad-5.8067000 .5124276 .127997$
H $\quad-6.9639760 .2369794 .791877$
H $1.165594-2.5887500 .392682$
H $\quad-5.829519-1.9013695 .201331$
H $\quad-6.347928-1.5870833 .520853$ 

H $\quad-5.083790-2.7992273 .854206$
C $\quad-3.8483821 .7073714 .492937$
H $\quad-4.2605512 .7207724 .386315$
$\mathrm{H} \quad-2.9957351 .6207663 .806931$
H $\quad-3.4970511 .5791855 .526331$
H $\quad-3.7930622 .112289-1.215731$
C $\quad-3.5308282 .980784-0.591865$
H $\quad-2.4585443 .193692-0.704096$
H $\quad-4.0903583 .858290-0.944543$
C $\quad-3.8415572 .6982900 .867656$
O $\quad-3.2410421 .4786231 .285758$
$\mathrm{H} \quad-2.2657911 .4424051 .140553$
C $\quad-3.4388733 .8536261 .757019$
C $\quad-4.3991054 .6995822 .314878$
H $\quad-5.4577784 .5077032 .124220$
C $\quad-4.0161765 .7689233 .126147$
H $\quad-4.7752306 .4224863 .558599$
C $\quad-2.6667725 .9931913 .395542$
H $\quad-2.3658876 .8207414 .039421$
C $\quad-1.7025965 .1498452 .840499$
$\mathrm{H} \quad-0.6458725 .3148023 .062580$
C $\quad-2.0858764 .0933342 .015888$
H $\quad-1.3327243 .4216251 .586961$
H $\quad-4.9218702 .5358890 .984733$
O $2.9146621 .369967-1.636759$
C $2.5550521 .306835-3.012798$
C $3.7407071 .905555-3.754385$
C $4.9054261 .357442-2.932072$
C $4.3411661 .365362-1.507835$
H $5.8269661 .945765-3.023439$
H $5.1311390 .327211-3.244046$
H $4.6610260 .485567-0.931850$
H $4.6382942 .269134-0.947410$
H $1.6191551 .860204-3.159664$
H $2.3826930 .257021-3.309276$
H $3.7063973 .004372-3.697261$
H $3.7763671 .616041-4.812213$ 


\section{C+iPrOBPin}
Al 0.9275381 .0373440 .074935
O $1.845836-0.4527300 .519453$
$\mathrm{N} \quad 2.2252142 .1925591 .033713$
C 1.8128023 .5972751 .046823
H $\quad 0.9641433 .6671801 .750104$
O $\quad-0.2630640 .157705-0.978835$
$\mathrm{N} \quad 0.3020142 .803396-0.651310$
C $1.2392073 .891737-0.349982$
H $2.0775463 .777726-1.065159$
C $0.6979355 .313103-0.458733$
H $\quad-0.1952525 .4112290 .181172$
H $\quad 0.3839865 .526961-1.490864$
$\mathrm{N} \quad-2.316457-2.653126-1.20474$
C $1.7635296 .325612-0.034836$
H $\quad 1.3469047 .340937-0.084724$
H $2.6004666 .293940-0.752798$
C 2.2907926 .0328081 .366973
H 1.4704246 .1399462 .096399
H 3.0603736 .7649001 .648052
C 2.8635584 .6180011 .462389
H 3.7489184 .5205270 .808944
H 3.1959094 .4259732 .493261
C 3.2505281 .7588771 .686678
H 3.8643142 .4755872 .250628
C 3.7120770 .3958871 .725793
C $3.021004-0.6544811 .048087$
C $3.669831-1.9229510 .911735$
C $4.849918-2.1205871 .619458$
H $\quad 5.345592-3.0888031 .559690$
C $5.465559-1.1233452 .398915$
C 4.9164790 .1378642 .415574
H 5.4076840 .9548102 .950183
C $\quad-0.7326662 .976406-1.396014$
H $\quad-0.9783493 .987804-1.746690$
C $-1.5823391 .924284-1.909080$
C $\quad-1.2641730 .550507-1.715173$ 

C $\quad-2.034587-0.417653-2.415458$
C $-3.084985-0.008080-3.230384$
H $\quad-3.658432-0.762660-3.775119$
C $\quad-3.4290691 .338893-3.377433$
C $\quad-2.6691842 .290039-2.723145$
$\mathrm{H} \quad-2.9026983 .351220-2.840559$
C $-1.644964-1.860377-2.316823$
H $\quad-1.876078-2.390874-3.248786$
H $\quad-0.568498-1.943899-2.112675$
C $-3.818390-2.661689-1.351315$
H $\quad-4.127191-1.607276-1.322522$
H $\quad-4.203597-3.116035-0.429017$
C $\quad-1.730599-4.039528-1.261213$
H $\quad-0.658086-3.904736-1.070401$
H $\quad-1.847995-4.386727-2.296349$
C $\quad-2.323833-5.041023-0.289929$
H $\quad-2.186761-4.7442100 .757628$
H $\quad-1.797078-5.994617-0.428989$
H $\quad-3.390465-5.227102-0.471537$
C $\quad-1.999671-2.0146380 .109462$
$\mathrm{H} \quad-2.404084-2.6432950 .909321$
H $\quad-2.492763-1.0357570 .157173$
H $\quad-0.913529-1.9040610 .198973$
C $\quad-4.338072-3.393790-2.572578$
H $\quad-5.428914-3.271778-2.597376$
H $\quad-4.130309-4.472290-2.544778$
H $\quad-3.948267-2.989336-3.516522$
H $\quad-4.2703421 .630682-4.004019$
C $3.119298-2.985978-0.049989$
H $\quad 6.389012-1.3419572 .934484$
Cl $-4.3606680 .663507-0.144110$
C $2.998839-2.374943-1.459613$
C $\quad 1.748179-3.4963270 .411582$
C $4.055567-4.195709-0.148575$
H $\quad 5.059542-3.910892-0.496477$
H $\quad 3.642587-4.914940-0.870682$
H $4.154421-4.7151220 .815719$ 

H $\quad 3.989588-2.056280-1.821828$
H $2.317393-1.512168-1.464147$
H $2.615619-3.131785-2.162722$
H $\quad-6.6768581 .3928224 .460448$
H $\quad 1.831265-3.9895011 .389361$
H $\quad 1.374963-4.239550-0.313059$
O $\quad-0.2900121 .2278011 .588361$
C $\quad-0.2023490 .9651803 .016901$
C $\quad 0.4030602 .1305143 .780605$
H $\quad-0.1432183 .0539463 .560017$
$\mathrm{H} \quad 1.4659892 .2850083 .553811$
$\mathrm{H} \quad 0.3154071 .9353834 .858551$
C $0.449597-0.3701093 .310265$
C $1.666474-0.4984923 .981832$
$\mathrm{H} \quad 2.2305540 .3841174 .284957$
C $2.177734-1.7620274 .290984$
H $3.134247-1.8458014 .809824$
C $\quad 1.462440-2.9063883 .951065$
H $1.853386-3.8925484 .207925$
C $0.234294-2.7845913 .294846$
H $\quad-0.338437-3.6808943 .042983$
C $\quad-0.262586-1.5271452 .971459$
H $\quad-1.237424-1.3973792 .497394$
H $\quad-1.2550590 .8631633 .316851$
B $\quad-3.7029891 .0669081 .700055$
O $\quad-3.124410-0.1201092 .275338$
O $\quad-4.8302961 .4292022 .483672$
C $\quad-4.075336-0.6427803 .206031$
C $\quad-4.8162620 .6543733 .671229$
C $\quad-3.356336-1.3811584 .325260$
C $\quad-5.017326-1.5995512 .471486$
$\mathrm{H} \quad-2.930547-2.3258653 .954870$
H $\quad-2.534894-0.7830634 .742179$
H $\quad-4.060540-1.6259305 .134719$
C $\quad-6.2450000 .4337014 .142544$
H $\quad-6.279826-0.2598664 .996440$
H $\quad-6.8656400 .0380103 .329723$ 

H $\quad 1.032975-2.6693390 .508341$
H $\quad-5.731957-2.0704053 .161221$
H $\quad-5.565515-1.0727281 .678452$
H $\quad-4.416798-2.3995542 .010216$
C $\quad-4.0223981 .4151574 .737619$
H $\quad-4.4788432 .4063714 .871241$
H $\quad-2.9797531 .5601654 .414801$
H $\quad-4.0242880 .8986415 .707960$
H $\quad-4.1693083 .314092-0.301415$
C $\quad-3.5200434 .0207440 .232151$
$\mathrm{H} \quad-2.6223994 .210618-0.375306$
$\mathrm{H} \quad-4.0495684 .9771120 .350905$
C $\quad-3.1433613 .4675951 .599308$
H $\quad-4.0470033 .4664642 .224300$
O $\quad-2.6862182 .1162131 .529283$
H $\quad-1.2380501 .6060231 .437054$
C $\quad-2.0777644 .3090872 .278287$
H $\quad-1.1104404 .1619021 .769365$
$\mathrm{H} \quad-2.3354155 .3769462 .231179$
H $\quad-1.9677184 .0282873 .334793$
O $2.1917371 .150887-1.622780$
C $1.6840471 .043215-2.965774$
C $2.8393911 .489782-3.843229$
C $4.0366250 .932401-3.077161$
C $3.6344261 .166712-1.626318$
H $4.9876241 .417990-3.327932$
H $\quad 4.139295-0.144982-3.271910$
H $4.0031430 .388251-0.947065$
H $3.9653912 .151331-1.256935$
H $\quad 0.7886411 .668853-3.054030$
H $\quad 1.400363-0.004886-3.152461$
H $2.8826622 .588728-3.885775$
H $2.7582481 .109315-4.868798$
C
Al 0.5655880 .7452820 .298645
O $1.523361-0.7234960 .741364$
N 1.4202281 .7907021 .762949 

C $\quad 0.8191453 .1139511 .946739$
H $\quad-0.1597132 .9477262 .429486$
O $\quad-0.1981980 .053897-1.207697$
$\mathrm{N} \quad-0.1696772 .564296-0.169782$
C $\quad 0.5097613 .6482160 .538119$
H 1.4842173 .7847980 .027702
C $\quad-0.2051854 .9918980 .591598$
H $\quad-1.2039544 .8524201 .040601$
H $\quad-0.3553695 .386172-0.424367$
$\mathrm{N} \quad-1.643603-2.920247-2.128891$
C 0.6025235 .9929921 .418844
H $\quad 0.0659666 .9503571 .468402$
H $\quad 1.5605656 .1957730 .910964$
C $\quad 0.8757775 .4607972 .822684$
H $\quad-0.0800725 .3344003 .358031$
H 1.4661966 .1848833 .400510
C $\quad 1.6064384 .1176832 .778222$
H 2.6119524 .2486842 .339533
$\mathrm{H} \quad 1.7432683 .7405233 .802671$
C 2.3902991 .3630742 .498798
H 2.7932332 .0199813 .282064
C 3.0472710 .0868542 .375866
C $2.611158-0.8991641 .440197$
C $3.411028-2.0705181 .254144$
C $\quad 4.531775-2.2265892 .062117$
H $\quad 5.150958-3.1145481 .938957$
C $4.923363-1.2882633 .034910$
C $4.188605-0.1339973 .177736$
H 4.4861930 .6311973 .898935
C $-1.1714302 .765116-0.951029$
$\mathrm{H} \quad-1.5910163 .775676-1.048844$
C $-1.7854411 .753945-1.779822$
C $\quad-1.2362730 .443987-1.893818$
C $-1.832858-0.450700-2.821579$
C $\quad-2.955128-0.050695-3.540187$
H $\quad-3.397659-0.741948-4.261609$
C $\quad-3.5353661 .210287-3.373816$ 

C $\quad-2.9356632 .103981-2.506599$
H $\quad-3.3528123 .105685-2.378185$
C $\quad-1.207795-1.791949-3.057078$
H $\quad-1.429779-2.137994-4.074358$
H $\quad-0.118223-1.731796-2.930910$
C $\quad-3.147342-3.043789-2.068994$
H $\quad-3.511075-2.060329-1.734615$
H $\quad-3.355899-3.741540-1.247527$
C $\quad-0.985439-4.172003-2.648682$
H $\quad 0.094479-3.970291-2.608049$
H $\quad-1.268611-4.258548-3.705804$
C $\quad-1.321169-5.449231-1.902703$
H $\quad-0.986362-5.431381-0.857740$
H $\quad-0.793331-6.274690-2.398844$
H $\quad-2.393429-5.683171-1.930672$
C $-1.162726-2.637913-0.741745$
H $\quad-1.342130-3.523780-0.124803$
H $\quad-1.739788-1.793721-0.343441$
H $\quad-0.096285-2.395607-0.775964$
C $\quad-3.795108-3.517614-3.355094$
H $\quad-4.883524-3.441052-3.233236$
H $\quad-3.563278-4.566073-3.587654$
H $\quad-3.523801-2.904352-4.224522$
H $\quad-4.4265881 .487547-3.934546$
C $3.026990-3.1061530 .190521$
H $5.808311-1.4695723 .644171$
Cl $\quad-3.524976-0.2956380 .212783$
C $2.856165-2.432507-1.186862$
C $\quad 1.729040-3.8005490 .634187$
C $4.107258-4.1821410 .029077$
H $5.073341-3.749505-0.271742$
H $3.798355-4.891144-0.753037$
H $4.255288-4.7586930 .953109$
H $3.796452-1.943063-1.489125$
H $\quad 2.055130-1.681767-1.190659$
H $\quad 2.634190-3.202401-1.944068$
H $\quad 1.929362-4.4566751 .492862$ 

H $\quad 1.330609-4.425923-0.183765$
O $\quad-1.0114170 .3796321 .351435$
C $-1.362665-0.1099172 .669431$
C $\quad-1.0376820 .8959033 .758712$
H $\quad-1.5634941 .8406403 .564241$
H $\quad 0.0380401 .0933803 .856156$
H $\quad-1.3947330 .5039124 .720874$
C $\quad-0.832858-1.5067202 .931462$
C $0.354601-1.7473523 .629904$
H $\quad 0.971561-0.9139873 .970967$
C $0.754953-3.0509163 .922899$
H $\quad 1.682449-3.2217684 .472757$
C $\quad-0.036126-4.1298523 .528478$
H $\quad 0.265636-5.1488233 .777459$
C $-1.216926-3.9011492 .821037$
H $\quad-1.845927-4.7428682 .523497$
C $-1.613110-2.5962052 .524535$
H $\quad-2.547795-2.3953711 .989991$
H $\quad-2.457145-0.1967262 .616040$
H $\quad 0.964109-3.0761060 .944894$
H $\quad-1.8864490 .2204090 .795482$
O $2.1218611 .329983-0.957945$
C $\quad 1.8892301 .567668-2.361587$
C $3.1289022 .311619-2.821031$
C $4.2172801 .611460-2.010713$
C $3.5346021 .387865-0.665497$
H $5.1422932 .192769-1.914480$
H $4.4674760 .645416-2.472872$
H $3.8401630 .452825-0.181000$
H 3.7010472 .2233810 .033223
H $\quad 0.9541222 .130127-2.466561$
H $1.7748340 .596395-2.867562$
H $3.0604203 .374922-2.544857$
H $3.2797832 .246559-3.905410$

\section{$\mathbf{C}+\mathbf{1 a}$}
Al 0.7064440 .8060700 .168468
O $1.594558-0.6847160 .624703$ 
$\mathrm{N} \quad 1.4531011 .7809181 .716270$

C 0.7735413 .0563061 .945465

$\mathrm{H} \quad-0.2367852 .8056702 .316845$

O $\quad 0.0093370 .153685-1.377086$

N $\quad 0.0050142 .647428-0.301222$

C $\quad 0.5668443 .6948310 .559870$

H $\quad 1.5733793 .9208270 .156153$

C $\quad-0.2318954 .9892550 .663127$

H $\quad-1.2562814 .7432410 .994253$

H $\quad-0.3101415 .477738-0.319046$

N $\quad-1.874964-2.640607-1.967521$

C $\quad 0.4228095 .9505121 .656851$

H $\quad-0.1823076 .8637831 .739593$

$\mathrm{H} \quad 1.4065096 .2605871 .265741$

C 0.6047535 .3034383 .027216

H $\quad-0.3834045 .0657143 .455774$

H 1.0891186 .0034603 .721375

C 1.4271544 .0183202 .926316

H 2.4519994 .2528182 .587310

$\mathrm{H} \quad 1.5090153 .5494003 .918646$

C 2.4403091 .3592232 .434770

$\mathrm{H} \quad 2.8135811 .9927623 .251623$

C 3.1261660 .1021802 .263519

C $2.673945-0.8810721 .331654$

C $3.427189-2.0828031 .163637$

C $4.557778-2.2501521 .955387$

H $5.151582-3.1568011 .843744$

C $4.986701-1.3016252 .903468$

C $4.272599-0.1344393 .053056$

H 4.5888580 .6246513 .772762

C $\quad-0.8141692 .911922-1.258135$

H $-1.1586823 .945345-1.404676$

C $-1.3427321 .944783-2.195032$

C $\quad-0.9297570 .581826-2.168989$

C $\quad-1.579757-0.337766-3.033912$

C $\quad-2.5663320 .118076-3.902624$

H $\quad-3.047105-0.595573-4.577119$ 

C $\quad-2.9643941 .460445-3.937835$
C $\quad-2.3518482 .358336-3.081666$
$\mathrm{H} \quad-2.6587083 .407516-3.078707$
C $\quad-1.166569-1.780439-3.001802$
H $\quad-1.348568-2.256202-3.973553$
H $\quad-0.098700-1.859762-2.758104$
C $\quad-3.376490-2.598601-2.139175$
H $\quad-3.635370-1.532954-2.100156$
H $\quad-3.811994-3.015160-1.219955$
C $\quad-1.321594-4.032683-2.114908$
H $\quad-0.233993-3.927663-1.993433$
H $\quad-1.513806-4.339542-3.151414$
C $-1.873366-5.044505-1.130013$
H $\quad-1.577571-4.819858-0.097059$
H $\quad-1.459529-6.028441-1.387790$
H $\quad-2.968106-5.119944-1.173455$
C $\quad-1.577021-2.134249-0.594631$
H $\quad-2.086648-2.7732240 .129041$
H $\quad-2.024051-1.141720-0.503129$
H $\quad-0.490498-2.102974-0.451868$
C $\quad-3.892283-3.276656-3.391375$
H $\quad-4.970537-3.080643-3.457810$
H $\quad-3.765280-4.367339-3.360424$
H $\quad-3.434717-2.899975-4.317502$
$\mathrm{H} \quad-3.7414061 .787658-4.627540$
C $2.978006-3.1353130 .141285$
H $\quad 5.878009-1.4927753 .500427$
Cl $-4.440223-1.8754751 .012490$
C $2.817308-2.506327-1.257942$
C $1.647766-3.7494470 .611445$
C $4.002921-4.2682580 .014270$
H $4.982302-3.898023-0.325166$
H $3.644909-4.998855-0.725699$
H $4.141511-4.8051290 .963450$
H $\quad 3.756067-2.021728-1.573049$
H $2.010914-1.761683-1.286285$
H $\quad 2.599238-3.300677-1.990212$ 

H $\quad 1.806654-4.3612131 .510407$
H $\quad 1.237920-4.408172-0.173376$
O $\quad-0.9657540 .4489461 .134121$
C $-1.522669-0.1639462 .353233$
C -1.5870370 .8720333 .461995$
H $\quad-2.1496891 .7588673 .139456$
H $\quad-0.5796021 .1761223 .786449$
H $\quad-2.1022750 .4372724 .329432$
C $\quad-0.800445-1.4194882 .796917$
C $\quad 0.449264-1.3585773 .420595$
H $\quad 0.949270-0.3976953 .536898$
C $1.060751-2.5047743 .922362$
H $2.044600-2.4336484 .392162$
C $0.402114-3.7327003 .840020$
H $\quad 0.866130-4.6313414 .250905$
C $\quad-0.858124-3.8022623 .247693$
H $\quad-1.391302-4.7540953 .208973$
C $\quad-1.460199-2.6538132 .727112$
H $\quad-2.470791-2.6933702 .304063$
H $\quad-2.542327-0.4667822 .061835$
H $\quad 0.906361-2.9790740 .866761$
H $\quad-1.7575870 .6948440 .574607$
O $2.3402571 .414624-0.990431$
C $2.1965821 .612466-2.412918$
C $3.4503762 .367155-2.808031$
C $4.4981661 .683296-1.934323$
C $3.7419131 .436249-0.631587$
H $5.4047162 .280740-1.779036$
$\mathrm{H} \quad 4.7952700 .725647-2.385190$
H $4.0107230 .481846-0.165178$
H 3.8861142 .2450230 .101499
H $\quad 1.2649542 .158124-2.596379$
H $2.1321800 .627591-2.901004$
H $3.3529883 .431129-2.543745$
H $3.6619372 .295844-3.881873$
C $\quad-4.3879751 .6482131 .404269$
C $\quad-5.0689131 .1093112 .500585$ 

H $\quad-5.4504310 .0872282 .432029$
C $\quad-5.1721021 .8600043 .672046$
$\mathrm{H} \quad-5.6824991 .4370104 .538554$
C $\quad-4.6323533 .1461683 .742305$
H $\quad-4.7347853 .7300054 .658380$
C $\quad-3.9651223 .6868732 .641910$
H $\quad-3.5557164 .6980412 .692106$
C $\quad-3.8294012 .9309021 .478328$
H $\quad-3.3082753 .3366680 .606439$
C $\quad-4.2323670 .9242590 .102225$
C $-5.4693830 .600868-0.673452$
H $\quad-5.2063570 .086183-1.604864$
H $\quad-5.9909251 .545209-0.898132$
H $\quad-6.121000-0.037513-0.064588$
O $\quad-3.1101250 .799563-0.374356$

\section{TS5}

Al $0.8297391 .258212-0.381923$

O $1.513683-0.2229390 .322001$

$\mathrm{N} \quad 1.1012352 .2634501 .264972$

C $\quad 0.5037163 .6045211 .250122$

H $\quad-0.5732173 .4782781 .451792$

O $\quad-0.0071030 .379753-1.692646$

N $\quad 0.0860422 .994517-1.019198$

C $\quad 0.5902194 .101318-0.205153$

H $1.6644424 .208211-0.452291$

C $\quad-0.0918425 .450467-0.375884$

H $\quad-1.1719395 .338274-0.176500$

H $\quad 0.0179705 .808333-1.410916$

N $\quad-2.170348-2.371175-1.789028$

C $\quad 0.5080726 .4680000 .596241$

H $\quad-0.0008757 .4345650 .480767$

H $\quad 1.5667756 .6374370 .337490$

C $\quad 0.4073145 .9809302 .039612$

$\mathrm{H} \quad-0.6551115 .8969842 .323564$

H $\quad 0.8574386 .7129682 .723718$

C $\quad 1.0820924 .6206092 .225944$

H 2.1703964 .7069062 .058483 

H $\quad 0.9365434 .2831283 .262267$
C 1.7200431 .7943672 .306611
H 1.8005532 .4295093 .197416
C 2.3686020 .5202812 .405705
C $2.264314-0.4525481 .372760$
C $3.015336-1.6585711 .465049$
C $3.769216-1.8534172 .618107$
H $\quad 4.346547-2.7713302 .723167$
C $3.819338-0.9287433 .677202$
C 3.1268510 .2556083 .566260
H 3.1603051 .0017334 .363279
C $\quad-0.7875713 .144806-1.948780$
$\mathrm{H} \quad-1.1620804 .150625-2.183528$
C $-1.3581952 .063151-2.722838$
C $\quad-0.9738000 .709656-2.505992$
C $-1.677157-0.314343-3.193865$
C $\quad-2.6471470 .040250-4.128683$
H $\quad-3.161535-0.749400-4.680827$
C $\quad-2.9959641 .373660-4.377000$
C $\quad-2.3608622 .371887-3.660831$
$\mathrm{H} \quad-2.6381913 .417795-3.812800$
C $-1.353656-1.758003-2.910766$
H $\quad-1.524802-2.373707-3.802155$
H $\quad-0.305598-1.861239-2.600610$
C $\quad-3.655542-2.265086-2.048674$
H $\quad-3.860423-1.193752-2.166958$
H $\quad-4.153248-2.559350-1.110391$
C $-1.750480-3.815456-1.641434$
H $\quad-0.712696-3.777170-1.284646$
H $\quad-1.746732-4.249651-2.651052$
C $-2.624562-4.620743-0.696383$
$\mathrm{H} \quad-2.839956-4.0862250 .238643$
H $\quad-2.094148-5.549317-0.448086$
H $\quad-3.586132-4.890943-1.150164$
C $-1.863080-1.655310-0.509975$
$\mathrm{H} \quad-2.529266-2.0344250 .276500$
H $\quad-2.081552-0.595896-0.656909$ 

H $\quad-0.802181-1.785372-0.271287$
C $\quad-4.143731-3.060244-3.244134$
H $\quad-5.215221-2.854143-3.367367$
H $\quad-4.039880-4.143098-3.098635$
H $\quad-3.649225-2.793223-4.188516$
H $\quad-3.7624881 .614344-5.112168$
C $3.030391-2.6614030 .303979$
H $4.409741-1.1496154 .565969$
Cl $\quad-4.622209-1.9880571 .236164$
C $3.734785-2.001939-0.896706$
C $1.607698-3.077412-0.117202$
C $3.798038-3.9343610 .677154$
$\mathrm{H} \quad 4.850047-3.7292280 .922835$
H $3.788809-4.626827-0.176185$
H $\quad 3.326451-4.4444131 .530877$
H $4.769224-1.724896-0.638013$
H $3.187999-1.101217-1.215890$
H $3.771507-2.701025-1.746707$
H $\quad 0.995398-3.3648010 .752847$
H $\quad 1.676047-3.943428-0.795229$
O $\quad-0.5781710 .0700152 .905940$
C $-1.525980-0.9798473 .069181$
C $\quad-2.256397-0.8441134 .401431$
H $\quad-2.7432300 .1371664 .473523$
$\mathrm{H} \quad-1.544161-0.9500305 .233135$
H $\quad-3.026489-1.6233454 .486307$
C $\quad-0.839640-2.3282963 .000566$
C $\quad 0.479522-2.4780883 .434740$
H $\quad 1.037560-1.5920463 .746217$
C $1.069086-3.7428423 .477576$
H $2.094791-3.8490193 .838859$
C $0.352644-4.8675023 .068434$
H $\quad 0.813497-5.8563973 .105356$
C $\quad-0.965298-4.7212622 .628471$
H $\quad-1.539028-5.5993642 .324429$
C $\quad-1.564149-3.4610752 .605821$
H $\quad-2.612107-3.3351352 .308082$ 


$$
\begin{aligned}
& \text { H } \quad-2.289691-0.9412282 .270677 \\
& \text { H } 1.112774-2.252430-0.643662 \\
& \text { H } \quad-0.9134720 .6546072 .214299 \\
& \text { O } 2.4616171 .709314-1.327425 \\
& \text { C } 2.5276641 .700612-2.776296 \\
& \text { C } 3.9363202 .179709-3.074771 \\
& \text { C } 4.7309791 .558607-1.924651 \\
& \text { C } 3.7907261 .724485-0.739748 \\
& \text { H } 5.6996872 .042445-1.751114 \\
& \text { H } 4.9094480 .490737-2.116649 \\
& \text { H } 3.8563250 .911587-0.004999 \\
& \text { H } 3.9148772 .692564-0.231346 \\
& \text { H } \quad 1.7282352 .352094-3.152438 \\
& \text { H } 2.3490150 .670943-3.118809 \\
& \text { H } 3.9849003 .277773-3.033385 \\
& \text { H } 4.2812331 .856791-4.064422 \\
& \text { C } \quad-3.4828491 .6873262 .234856 \\
& \text { C } \quad-4.7250391 .1694022 .632909 \\
& \text { H } \quad-5.2633490 .4689561 .990581 \\
& \text { C } \quad-5.2237881 .4734173 .898371 \\
& \text { H } \quad-6.1774841 .0503774 .215581 \\
& \text { C } \quad-4.5066162 .3059714 .757462 \\
& \mathrm{H} \quad-4.9100542 .5510695 .741254 \\
& \text { C } \quad-3.2620942 .8092704 .370976 \\
& \mathrm{H} \quad-2.6925823 .4432405 .051616 \\
& \text { C } \quad-2.7463172 .4862203 .121229 \\
& \mathrm{H} \quad-1.7615402 .8494922 .827188 \\
& \text { C } \quad-2.9448851 .4061770 .875797 \\
& \text { C } \quad-3.9291011 .082084-0.201206 \\
& \text { H } \quad-3.4520171 .122014-1.189434 \\
& \text { H } \quad-4.7930821 .758263-0.160577 \\
& \text { H } \quad-4.3029110 .0552720 .018792 \\
& \text { O } \quad-1.7301281 .4402260 .657174
\end{aligned}
$$

\section{$\mathbf{A}+\mathbf{2 a}$}
Al $\quad 0.5137241 .290522-0.243518$
O $\quad 1.227316-0.1634570 .536305$
N 1.0929732 .4607351 .250365 

C $\quad 0.5618253 .8222731 .135185$
H $\quad-0.5065233 .7789941 .424863$
O $\quad-0.0736730 .382140-1.702771$
$\mathrm{N} \quad-0.0164833 .042046-1.065921$
C $0.5825034 .179352-0.363630$
H $1.6455524 .202267-0.673688$
C $\quad-0.0324775 .547843-0.624448$
H $\quad-1.1063735 .515261-0.370348$
H $\quad 0.0460315 .808873-1.690297$
$\mathrm{N} \quad-2.195879-2.391316-1.919939$
C 0.6708726 .6140480 .217538
H $\quad 0.2047887 .5926190 .038986$
H $1.7200156 .700947-0.111582$
C $\quad 0.6306736 .2663441 .703087$
H $\quad-0.4157886 .2675012 .051070$
H $\quad 1.1571177 .0312882 .289894$
C $\quad 1.2463124 .8929921 .976670$
H 2.3249914 .9024361 .740046
H 1.1489764 .6580103 .046294
C 1.6959332 .0314292 .310593
H 1.8618282 .7256953 .145792
C 2.2397280 .7099392 .501026
C $2.070789-0.3219311 .533847$
C $2.821164-1.5253821 .652205$
C $3.558562-1.7014112 .821123$
H $\quad 4.113047-2.6287782 .961761$
C $3.628712-0.7386923 .842583$
C 2.9976530 .4732953 .665815
H 3.0819411 .2626184 .416189
C $\quad-0.7816533 .167157-2.08896$
H $-1.0533634 .170496-2.446162$
C $-1.3409332 .060644-2.844352$
C $\quad-0.9779370 .704375-2.581284$
C $\quad-1.644914-0.321949-3.307575$
C $\quad-2.5546900 .027298-4.303403$
H $\quad-3.036615-0.765936-4.879464$
C $\quad-2.8804761 .358081-4.588332$ 

C $\quad-2.2779342 .360594-3.849782$
H $\quad-2.5304933 .406775-4.039444$
C $\quad-1.340617-1.767244-3.011917$
H $\quad-1.483233-2.379404-3.911007$
H $\quad-0.304355-1.876458-2.665264$
C $\quad-3.674781-2.222645-2.184742$
H $\quad-3.835045-1.142336-2.291270$
H $\quad-4.188221-2.504383-1.251913$
C $\quad-1.824108-3.851373-1.820900$
H $\quad-0.777475-3.860871-1.485910$
$\mathrm{H} \quad-1.858157-4.257602-2.841334$
C $\quad-2.704518-4.651037-0.878899$
$\mathrm{H} \quad-2.828535-4.1589590 .093960$
H $\quad-2.224775-5.623584-0.707854$
H $\quad-3.702829-4.834217-1.294775$
C $\quad-1.883625-1.727988-0.616699$
$\mathrm{H} \quad-2.579245-2.0877070 .153079$
H $\quad-2.052395-0.660567-0.749439$
H $\quad-0.834404-1.906657-0.366753$
C $\quad-4.189665-2.983026-3.391607$
H $\quad-5.242298-2.707343-3.538276$
H $\quad-4.158825-4.070560-3.247189$
H $\quad-3.656672-2.746330-4.322771$
H $\quad-3.5978331 .594994-5.372541$
C $2.896136-2.5222930 .485397$
H $4.205100-0.9417904 .744660$
Cl $-4.642484-1.7689301 .130867$
C $3.604289-1.810572-0.683617$
C $1.511504-2.991279-0.000229$
C $3.713055-3.7629280 .861637$
$\mathrm{H} \quad 4.742623-3.5098901 .153088$
H $3.772856-4.433519-0.007035$
H $\quad 3.236862-4.3183851 .683151$
H $\quad 4.619285-1.496152-0.392866$
H $3.026744-0.926820-0.997040$
H $3.690336-2.489599-1.546343$
H $\quad 0.854427-3.2764020 .836653$ 

H $\quad 1.640158-3.870940-0.651456$
O $\quad-0.547199-0.3415123 .061733$
C $\quad-1.556660-1.3203883 .250810$
C $\quad-2.130286-1.1385434 .646005$
H $\quad-2.526096-0.1209624 .762403$
H $\quad-1.347318-1.3054385 .400576$
H $\quad-2.945279-1.8550774 .812190$
C $\quad-0.986958-2.7138433 .076680$
C $\quad 0.311268-2.9943833 .517183$
H $\quad 0.911382-2.1846173 .939322$
C $0.826875-4.2857113 .412626$
H $\quad 1.834817-4.5001093 .775678$
C $0.052504-5.3062542 .856588$
H $\quad 0.453534-6.3182802 .777312$
C $\quad-1.244933-5.0302192 .420666$
H $\quad-1.860701-5.8316042 .006610$
C $\quad-1.768311-3.7399842 .534706$
H $\quad-2.794017-3.5065182 .222758$
H $\quad-2.381747-1.1868382 .523934$
H $\quad 1.035663-2.190580-0.577969$
H $\quad-0.226149-0.4351622 .155551$
O $2.2686731 .637353-1.207191$
C $2.3869311 .563726-2.645432$
C $3.7585012 .146995-2.935347$
C $4.5630191 .661151-1.730319$
C $3.5652001 .810774-0.590243$
H $5.4818492 .233496-1.553886$
H $4.8354970 .603452-1.857273$
H 3.6835761 .0574050 .199312
H $3.5946692 .815481-0.138447$
H $1.5523262 .122874-3.087913$
H $2.3056060 .508561-2.945407$
H $3.7123663 .246383-2.953252$
H $4.1610111 .804678-3.896467$
C $\quad-2.8537261 .6260182 .352409$
C $\quad-4.1652341 .3439442 .772616$
H $\quad-4.8416960 .7755092 .130036$ 

C $\quad-4.5693561 .7116624 .053622$
H $\quad-5.5797711 .4753164 .388284$
C $\quad-3.6835102 .3715954 .906597$
H $\quad-4.0124812 .6734315 .902532$
C $\quad-2.3671412 .6178364 .505686$
H -1.6678413 .0962465 .192180$
C $\quad-1.9469122 .2227773 .241961$
H $\quad-0.9122452 .3511712 .929342$
C $\quad-2.4370521 .3370510 .967184$
C $\quad-3.5036621 .177515-0.054734$
H $\quad-3.0987361 .199638-1.072501$
H $\quad-4.2777751 .9447620 .071074$
H $\quad-3.9950470 .1898640 .157455$
O $\quad-1.2287911 .2549700 .676683$

\section{AI}

Al $1.2093291 .086475-0.895765$

O $1.879782-0.543395-0.474185$

N $\quad 2.8173841 .992674-0.162790$

C $2.6496233 .444349-0.043726$

H 2.0003283 .6128520 .837115

O $\quad-0.3366490 .458000-1.600008$

N $\quad 0.7129682 .969374-1.392690$

C $1.8418193 .893485-1.275784$

H $2.4866213 .706788-2.157583$

C $1.5129735 .379272-1.217998$

H $0.8327325 .567020-0.368443$

H $\quad 0.9872335 .692205-2.131890$

N $\quad-2.765478-1.867534-0.754241$

C $2.7919216 .201629-1.052497$

H $2.5385977 .268131-0.983509$

H $3.4170466 .084663-1.953679$

C 3.5835665 .7613770 .175553

$\mathrm{H} \quad 2.9934045 .9667291 .084215$

H 4.5094186 .3456520 .266031

C 3.9195684 .2698650 .123751

H $4.5991854 .062333-0.721862$

H 4.4465723 .9838991 .045162 

C 3.8706111 .3820060 .263203
$\mathrm{H} \quad 4.7000001 .9754020 .671462$
C $4.089145-0.0434240 .254279$
C $3.067380-0.964443-0.126663$
C $3.368261-2.362104-0.143679$
C $4.650582-2.7531090 .228762$
H $\quad 4.904975-3.8119110 .216779$
C $5.652771-1.8494490 .624391$
C $5.367438-0.5038060 .638608$
H 6.1258820 .2236380 .937863
C $\quad-0.4741403 .350418-1.716544$
H $\quad-0.6764594 .418943-1.874341$
C $\quad-1.6002102 .470449-1.929929$
C $-1.4687291 .053989-1.872053$
C $\quad-2.6131450 .262381-2.154571$
C $\quad-3.8118620 .875454-2.503316$
H $\quad-4.6831670 .252968-2.724407$
C $\quad-3.9401492 .267237-2.564963$
C $\quad-2.8407423 .048124-2.271418$
H $\quad-2.9237984 .137084-2.296428$
C $\quad-2.466790-1.226976-2.103504$
H $\quad-3.131537-1.717525-2.823910$
H $\quad-1.428881-1.503273-2.329232$
C $-4.235864-1.771415-0.416336$
H $\quad-4.471313-0.696125-0.392247$
H $\quad-4.324645-2.1111620 .623921$
C $\quad-2.289511-3.292897-0.854091$
H $\quad-1.207623-3.223307-1.033544$
H $\quad-2.751559-3.712921-1.757785$
C $\quad-2.573760-4.1637200 .353769$
$\mathrm{H} \quad-2.082814-3.7926371 .263315$
$\mathrm{H} \quad-2.167201-5.1633230 .148465$
H $\quad-3.647911-4.2802590 .549209$
C $\quad-2.016239-1.1531260 .325697$
H $\quad-2.172433-1.6820001 .272567$
H $\quad-2.440052-0.1416350 .424208$
H $\quad-0.954222-1.1205570 .055337$ 

C $\quad-5.165039-2.548941-1.325186$
H $\quad-6.189072-2.376725-0.967835$
H $\quad-4.987899-3.633180-1.301488$
$\mathrm{H} \quad-5.132537-2.210103-2.369794$
H $\quad-4.8987292 .721922-2.808194$
C $2.296392-3.387163-0.540420$
H $6.637218-2.2172140 .912033$
I $\quad-4.5055941 .7111741 .103953$
C $1.709289-3.068906-1.929308$
C $1.181862-3.3749380 .519404$
C $\quad 2.870827-4.807804-0.598059$
H $3.690083-4.887905-1.327742$
H $2.079389-5.506174-0.905812$
H $3.242309-5.1418970 .381521$
H $\quad 2.506713-3.045993-2.688988$
H $1.184069-2.104286-1.937929$
H $1.005785-3.865353-2.221762$
H $\quad 1.596565-3.5986261 .513965$
H $\quad 0.432262-4.1500040 .289807$
O $\quad 0.3912391 .3082010 .829935$
C $\quad-0.4049741 .5860401 .736880$
C -1.0343462 .9257821 .819645$
H $\quad-0.5169983 .6394531 .168843$
H $\quad-1.0831283 .2907362 .853142$
H $\quad-2.0900082 .8019001 .474791$
C $\quad-0.7521610 .5323542 .705938$
C $\quad-1.9094700 .6335593 .491328$
$\mathrm{H} \quad-2.5680201 .4993273 .408471$
C $\quad-2.262205-0.4239184 .329175$
H $\quad-3.176994-0.3591554 .918772$
C $-1.450577-1.5550434 .405636$
$\mathrm{H} \quad-1.723304-2.3719325 .076472$
C $\quad-0.284894-1.6503383 .633851$
H $\quad 0.349939-2.5342643 .708951$
C $0.058306-0.6148692 .774582$
H $\quad 0.949726-0.6733122 .145365$
H $\quad 0.685376-2.3961580 .561074$ 

O $\quad 2.0407400 .989379-2.726151$
C $1.2373231 .097485-3.922816$
C $2.2602781 .229948-5.034475$
C $3.3555810 .279234-4.553487$
C $3.3717790 .521229-3.047488$
H $4.3341450 .466022-5.011901$
H $3.072336-0.761577-4.766492$
H $\quad 3.580248-0.385870-2.466953$
H $\quad 4.0816851 .309939-2.753549$
H $\quad 0.5691901 .959083-3.807517$
H $\quad 0.6290320 .185581-4.018451$
H $\quad 2.6356572 .263055-5.088158$
H $\quad 1.8481090 .962530-6.015051$

\section{TS2I}

Al $1.0404981 .075714-0.840699$

O $1.706407-0.569027-0.422218$

$\mathrm{N} \quad 2.4458211 .9806650 .243150$

C 2.2385343 .4277500 .359161

H 1.4126943 .5718641 .079668

O $\quad-0.2476530 .474841-1.972251$

$\mathrm{N} \quad 0.6375762 .982773-1.377008$

C $1.7055493 .906720-1.005183$

H $2.5222683 .743470-1.736035$

C $1.3568115 .388723-0.980033$

H $\quad 0.5130005 .548846-0.286101$

H $1.0284505 .721516-1.976129$

N $\quad-2.669349-1.860320-1.315477$

C $2.5646406 .212176-0.531009$

H $2.2947647 .276386-0.493355$

H $3.3672726 .117311-1.281277$

C 3.0815805 .7447350 .826857

$\mathrm{H} \quad 2.3096365 .9267211 .593061$

H 3.9624216 .3296101 .125355

C 3.4340584 .2561410 .813910

H 4.2807634 .0726920 .128958

H 3.7551833 .9502191 .820076

C 3.3907121 .3692880 .869664 

$\mathrm{H} \quad 4.0887701 .9552161 .482533$
C $3.659831-0.0487690 .835124$
C $2.806831-0.9740600 .161761$
C $3.177253-2.3551720 .134952$
C $4.353867-2.7243360 .783028$
H $4.659792-3.7695710 .767006$
C $5.181766-1.8179841 .464947$
C $4.829001-0.4878331 .489827$
H 5.4526190 .2444372 .008049
C $-0.4769163 .363109-1.891086$
$\mathrm{H} \quad-0.6730514 .434086-2.040391$
C $-1.5327322 .469156-2.321346$
C $\quad-1.3655701 .054812-2.316468$
C $-2.4654110 .251197-2.721481$
C $\quad-3.6341050 .852386-3.179702$
H $\quad-4.4633290 .219172-3.507088$
C $\quad-3.7813952 .242178-3.223343$
C $\quad-2.7365783 .033726-2.782607$
H $\quad-2.8413024 .121243-2.779386$
C $\quad-2.317324-1.238871-2.661364$
H $\quad-2.956684-1.732473-3.403032$
H $\quad-1.271802-1.520152-2.843429$
C $-4.126058-1.647526-0.971196$
H $\quad-4.283365-0.561232-1.009238$
H $\quad-4.229198-1.9153110 .088972$
C $\quad-2.314521-3.318867-1.408395$
H $\quad-1.234639-3.344923-1.612363$
H $\quad-2.831631-3.711032-2.294371$
C $-2.645343-4.139255-0.177046$
$\mathrm{H} \quad-2.100695-3.7946210 .711438$
H $\quad-2.338575-5.176255-0.369195$
H $\quad-3.720011-4.1470520 .047807$
C $-1.859773-1.210051-0.241000$
H $\quad-2.106474-1.6715260 .719765$
H $\quad-2.151003-0.154255-0.194085$
H $\quad-0.799929-1.297435-0.500151$
C $\quad-5.110295-2.391036-1.850205$ 

H $\quad-6.120012-2.096684-1.534387$
H $\quad-5.040968-3.482585-1.747744$
H $\quad-5.020031-2.133042-2.914722$
H $\quad-4.7104592 .688568$ - 3.574357
C $2.284747-3.403300-0.546187$
H $\quad 6.087068-2.1685851 .959184$
I $\quad-4.3935421 .8720300 .565516$
C $1.926746-2.996900-1.988958$
C $\quad 1.006974-3.5704830 .292324$
C $2.973537-4.772584-0.618114$
H $3.921618-4.723731-1.174148$
H $\quad 2.314127-5.481169-1.139102$
H $\quad 3.175445-5.1885380 .379011$
H $\quad 2.841878-2.846512-2.584083$
H $\quad 1.333907-2.074196-2.023062$
H $1.357258-3.810734-2.466008$
H $\quad-5.6383121 .6924184 .464995$
H $\quad 1.253553-3.9157071 .307574$
H $\quad 0.348154-4.326336-0.166013$
O $\quad-0.1711361 .2376150 .592881$
C $\quad-0.6042751 .4987671 .753757$
C -1.1738972 .8695232 .002379$
H $\quad-1.5992003 .2555161 .067743$
H $\quad-0.3547273 .5221522 .348324$
H $\quad-1.9573142 .8565502 .770536$
C $\quad-0.0808740 .7084572 .907240$
C $\quad-0.2737551 .1241364 .231500$
$\mathrm{H} \quad-0.8529042 .0204824 .451145$
C $\quad 0.2616440 .3751885 .278506$
H $\quad 0.1119530 .7042736 .307882$
C $0.982010-0.7908095 .015111$
H $1.398968-1.3706465 .839915$
C $1.164908-1.2151703 .696906$
H $1.727319-2.1260463 .482282$
C $0.630882-0.4707292 .649806$
H $\quad 0.757482-0.7904551 .616273$
H $\quad-2.0732890 .7674541 .703749$ 

B -3.1998790 .5384242 .231480$
O $\quad-3.655990-0.7936622 .188235$
O $\quad-3.3028811 .0498233 .522054$
C $\quad-3.899977-1.2047073 .542807$
C $\quad-4.1456910 .1622624 .270197$
C $\quad-2.640540-1.9097474 .043260$
C $\quad-5.086753-2.1541053 .566186$
H $\quad-2.404057-2.7424263 .363564$
H $\quad-1.785193-1.2175584 .053940$
H $\quad-2.775004-2.3196205 .054247$
C -5.5879950 .6452584 .136326$
H $\quad-6.2700170 .0481654 .758093$
H $\quad-5.9234540 .6052183 .090359$
H $\quad 0.458274-2.6237400 .376414$
H $\quad-5.365486-2.4035154 .600785$
H $\quad-5.955453-1.7140183 .061369$
H $\quad-4.822662-3.0903613 .052251$
C $\quad-3.7100520 .1844765 .725987$
H $\quad-3.9227711 .1731616 .156128$
H $\quad-2.634181-0.0107505 .820453$
H $\quad-4.262422-0.5680766 .308217$
O $2.2941661 .130590-2.457196$
C $1.7857921 .278832-3.800107$
C $3.0264561 .547462-4.630781$
C $4.0459650 .630067-3.957455$
C $3.6910630 .765983-2.480138$
H $5.0881310 .905005-4.160191$
H $3.896321-0.407380-4.289604$
H $3.827142-0.165438-1.917416$
H $4.2561591 .570975-1.984191$
H $1.0480652 .090327-3.798176$
H $\quad 1.2827790 .343931-4.088318$
H $3.3296192 .601384-4.536905$
H $2.8744791 .325696-5.694096$
Al $0.4319121 .089984-0.712287$
O $1.192737-0.439543-0.097091$ 
$\mathrm{N} \quad 1.6182102 .1988380 .447432$

C 1.2887093 .6284230 .430333

H $\quad 0.3923793 .7598171 .058649$

O $\quad-0.6471900 .301691-1.958015$

N $\quad-0.0755242 .909426-1.420976$

C $0.8566453 .959893-1.007339$

H $1.7512263 .840596-1.651293$

C $0.3658775 .397810-1.111574$

H $\quad-0.5466525 .507032-0.499262$

H $\quad 0.1012985 .644112-2.150621$

N $\quad-2.836611-2.351082-1.796843$

C $1.4472456 .360589-0.617858$

H $\quad 1.0779817 .393637-0.677814$

H $2.3196486 .299247-1.290336$

C 1.8793776 .0299940 .807912

H 1.0261676 .1732191 .491029

H 2.6724396 .7156631 .137636

C 2.3632724 .5845720 .930319

H 3.2905954 .4407310 .345775

H 2.5967094 .3709991 .983912

C 2.5997751 .7324341 .140069

H 3.2047492 .4266601 .739010

C 3.0331620 .3548751 .182353

C $2.323122-0.6868810 .512665$

C $2.879269-2.0041750 .506312$

C $4.078673-2.2072441 .182767$

H $4.521997-3.2023131 .184726$

C $4.761762-1.1897181 .870057$

C 4.2366480 .0827801 .866316

H 4.7512190 .8997422 .378130

C $-1.1169733 .152640-2.134483$

H $-1.3740084 .190778-2.384853$

C $-1.9955552 .144740-2.684185$

C $\quad-1.7141230 .753983-2.558784$

C $\quad-2.632616-0.165384-3.129157$

C $\quad-3.7668810 .306162-3.784929$

H $\quad-4.455866-0.411136-4.237532$ 

C $\quad-4.0540711 .669385-3.883776$
C $-3.1633762 .573825-3.334212$
H $\quad-3.3657103 .645648-3.396022$
C $\quad-2.340882-1.631438-3.050315$
H $\quad-2.797891-2.159349-3.896389$
H $\quad-1.256723-1.806594-3.062823$
C $\quad-4.311575-2.119734-1.566434$
H $\quad-4.430055-1.028193-1.486697$
H $\quad-4.523444-2.525584-0.568589$
C $\quad-2.505864-3.807819-1.995140$
H $\quad-1.412433-3.844785-2.102040$
H $\quad-2.943731-4.098131-2.959090$
C $-2.969211-4.744168-0.896115$
$\mathrm{H} \quad-2.497395-4.5313090 .071300$
H $\quad-2.676393-5.763433-1.181440$
H $\quad-4.059703-4.740296-0.769989$
C $\quad-2.117196-1.823419-0.597734$
H $\quad-2.364587-2.4593060 .258908$
H $\quad-2.476730-0.804660-0.406679$
H $\quad-1.040671-1.823161-0.797543$
C $\quad-5.222190-2.744221-2.604411$
H $\quad-6.248729-2.418456-2.391304$
H $\quad-5.213317-3.842322-2.572550$
H $\quad-4.988851-2.425692-3.628729$
$\mathrm{H} \quad-4.9566712 .009399-4.388972$
C $2.157678-3.151353-0.213679$
H $5.694924-1.4105732 .387232$
Cl $-3.7764261 .206532-0.094806$
C $1.863397-2.783918-1.681988$
C $\quad 0.852360-3.4511930 .542059$
C $2.999086-4.432984-0.227982$
H $3.961692-4.282443-0.739439$
H $\quad 2.452185-5.220067-0.767049$
H $3.197669-4.8078180 .786045$
H $\quad 2.801938-2.554856-2.212279$
H $\quad 1.195100-1.917230-1.768409$
H $\quad 1.405574-3.648159-2.190476$ 

H $\quad 1.073676-3.8500511 .542775$
H $\quad 0.259161-4.206842-0.000609$
O $\quad-1.0226661 .1146900 .544015$
C $\quad-1.1779641 .0397571 .976514$
C $\quad-0.311693-0.0497252 .570849$
H $\quad-0.543750-0.1601953 .638998$
H $\quad 0.7602770 .1632962 .470962$
H $\quad-0.514913-1.0045872 .068836$
C $\quad-0.9894502 .4228022 .571569$
C -1.8767293 .4309252 .164446$
$\mathrm{H} \quad-2.6944803 .1699421 .484365$
C $\quad-1.7142054 .7372082 .619617$
$\mathrm{H} \quad-2.4150595 .5131692 .306214$
C $\quad-0.6654245 .0522143 .489243$
H $\quad-0.5422036 .0739873 .852780$
C $\quad 0.2081354 .0508633 .910519$
H 1.0148464 .2880064 .606586
C $\quad 0.0434302 .7386963 .457037$
$\mathrm{H} \quad 0.7306211 .9632203 .801265$
$\mathrm{H} \quad-2.2375180 .7683752 .110136$
H $\quad 0.254280-2.5403400 .661030$
O $1.8636431 .165397-2.200155$
C $1.4884911 .203801-3.593121$
C $2.7496111 .663357-4.299690$
C $3.8268670 .938480-3.495889$
C $3.2953621 .027336-2.068425$
H $4.8252981 .381519-3.593857$
H $\quad 3.889008-0.112827-3.812302$
H $3.5175920 .132499-1.474427$
H $3.6704941 .913957-1.533604$
H $\quad 0.6321651 .879249-3.701782$
H $\quad 1.1815780 .192780-3.902005$
H $2.8623432 .754475-4.208961$
H 2.7509951 .404453 -5.365553
H $\quad-1.9991321 .2018410 .167827$

\section{TS2'}

Al $0.6555701 .124267-0.891015$ 

O $1.344712-0.436009-0.263050$
$\mathrm{N} \quad 1.9523222 .1719630 .216703$
C $\quad 1.6151443 .5969650 .281849$
H $\quad 0.7279093 .6803810 .939435$
O $\quad-0.5512170 .389024-2.031455$
N $\quad 0.1789292 .976891-1.540812$
C $1.1419563 .996393-1.129859$
H $2.0177163 .888795-1.800256$
C $0.6666495 .443111-1.165126$
H $\quad-0.2319275 .539224-0.530384$
H $\quad 0.3798745 .727697-2.188701$
N $\quad-2.866680-2.121121-1.528977$
C $1.7628276 .377788-0.652182$
H $1.4005877 .414922-0.663979$
H $2.6257816 .337742-1.337923$
C 2.2109495 .9842530 .752754
H 1.3659686 .1014141 .451337
H 3.0079376 .6534851 .104935
C 2.6980904 .5349430 .798380
H 3.6054514 .4212930 .178555
H 2.9709694 .2731041 .831183
C 2.9455211 .6643840 .860459
H 3.5990482 .3266501 .445275
C 3.3119360 .2673900 .880253
C $2.491310-0.7415750 .291982$
C $2.952779-2.0951740 .302267$
C $4.183402-2.3575010 .897794$
H $\quad 4.558371-3.3801250 .907272$
C $4.982159-1.3679381 .495306$
C $4.540521-0.0645041 .488955$
H 5.1395360 .7293871 .941692
C $\quad-0.9487163 .262288-2.086913$
H $\quad-1.2190894 .312829-2.261995$
C $-1.9305192 .289298-2.514876$
C $\quad-1.6795720 .888121-2.460061$
C $\quad-2.7002090 .008682-2.909162$
C $\quad-3.8922170 .526700-3.405944$ 

H $\quad-4.661818-0.163061-3.762077$
C $\quad-4.1411971 .901427-3.451711$
C $\quad-3.1594372 .766649-3.005212$
H $\quad-3.3324873 .845262-3.026413$
C $\quad-2.460179-1.469557-2.842068$
H $\quad-3.012974-1.995095-3.630366$
H $\quad-1.388773-1.684056-2.951106$
C $\quad-4.340057-1.933680-1.243164$
H $\quad-4.502005-0.847077-1.216987$
H $\quad-4.489452-2.257739-0.206222$
C $\quad-2.491228-3.574330-1.629180$
H $\quad-1.400657-3.584341-1.768803$
$\mathrm{H} \quad-2.948635-3.956777-2.551548$
C $-2.887948-4.422131-0.436214$
H $\quad-2.436718-4.0652390 .498362$
H $\quad-2.524253-5.443561-0.610458$
H $\quad-3.976230-4.475257-0.302550$
C $\quad-2.107329-1.482936-0.410849$
H $\quad-2.421421-1.9384680 .533487$
H $\quad-2.378634-0.422287-0.378657$
H $-1.036642-1.597434-0.611313$
C $\quad-5.269534-2.643607-2.205627$
H $\quad-6.298559-2.382240-1.924688$
H $\quad-5.186968-3.738005-2.152508$
H $\quad-5.134446-2.336581-3.252023$
H $\quad-5.0901522 .279440-3.829035$
C $2.101061-3.218990-0.304885$
H $5.933827-1.6359321 .952799$
Cl -4.0738381 .3458650 .132423$
C $1.705636-2.900108-1.760516$
C $\quad 0.847148-3.4022100 .565954$
C $2.854841-4.554385-0.323899$
H $3.779197-4.492896-0.917564$
H $\quad 2.214605-5.323746-0.778664$
H $3.111881-4.8990380 .687796$
H $2.605671-2.742133-2.376464$
H $\quad 1.072442-2.006298-1.833807$ 

H $\quad 1.167826-3.761921-2.188498$
H $\quad-3.727781-2.8856183 .374116$
H $\quad 1.126548-3.7443191 .573264$
H $\quad 0.181963-4.1624730 .123533$
O $\quad-0.6486151 .4267570 .464314$
C $\quad-0.8512011 .3121091 .697196$
C $\quad-0.1198220 .2477712 .466011$
H $\quad-0.650074-0.0456893 .377096$
H $\quad 0.8712330 .6486112 .742393$
H $\quad 0.034407-0.6239051 .821233$
C $\quad-1.4942432 .4461662 .395563$
C $\quad-2.0625163 .4703881 .622240$
H $\quad-2.0550503 .3688040 .536597$
C $\quad-2.6740464 .5532072 .242227$
H $\quad-3.1337225 .3387411 .641121$
C $\quad-2.7233244 .6214663 .636437$
H $\quad-3.2098445 .4688574 .122620$
C -2.1644563 .6045994 .409887$
H $\quad-2.2137353 .6542455 .497963$
C -1.5587062 .5146853 .792959$
H $\quad-1.1452851 .7161824 .408631$
H $\quad-2.3959680 .2729961 .702281$
В -3.6483250 .3131961 .785186$
O $\quad-4.0847100 .9500602 .965813$
O $\quad-4.278225-0.9771121 .702827$
C $\quad-5.2481510 .2685113 .420466$
C $\quad-4.979936-1.1936722 .925326$
C $\quad-6.4747130 .8889222 .748999$
C $\quad-5.3484050 .4156904 .930828$
H $\quad-6.4714221 .9676072 .957939$
H $\quad-6.4295670 .7585651 .658890$
H $\quad-7.4115210 .4578263 .131011$
C $\quad-4.055214-1.9609443 .872049$
H $\quad-4.556799-2.2326354 .811773$
H $\quad-3.165273-1.3592034 .109078$
H $\quad 0.292625-2.4615080 .665108$
H $\quad-6.172822-0.1925715 .332594$ 

H $\quad-4.4128500 .1180795 .421094$
$\mathrm{H} \quad-5.5444441 .4678185 .181354$
C $-6.233994-2.0078842 .644410$
$\mathrm{H} \quad-5.955137-3.0230342 .322280$
H $\quad-6.831926-1.5433171 .850237$
H $\quad-6.854912-2.0989913 .548110$
O $\quad 1.9740521 .109576-2.437738$
C $1.5094111 .200489-3.802901$
C $2.7619571 .534336-4.589537$
C $3.8088460 .690061-3.865226$
C $3.3881050 .812129-2.403549$
H $4.8386881 .029983-4.028198$
H $3.740165-0.357270-4.193183$
H $3.546626-0.111716-1.834178$
H $3.8923651 .643296-1.886507$
H $\quad 0.7225161 .962384-3.844831$
H $1.0790630 .229421-4.090045$
H $2.9949182 .606312-4.500611$
H $\quad 2.6650951 .289290-5.654151$

\section{Side Reactions}

\section{$\mathbf{H}_{2}$}

H $\quad 0.1228570 .000000-0.000000$

H $\quad 0.8771430 .000000-0.000000$

\section{TSSR1}

C $\quad 2.372004-0.128142-1.022460$

C $3.846937-0.494349-0.988605$

O $1.699416-0.896022-0.018985$

H $\quad 1.325109-2.025084-0.145032$

B $0.163313-1.042034-0.093199$

H $\quad 0.344161-2.453479-0.088710$

O $\quad-0.441388-0.659768-1.291980$

O $\quad-0.541948-0.5721021 .007744$

C $-1.6147530 .100713-0.969051$

C $-1.860862-0.2745060 .540513$

C $\quad-2.739341-0.312048-1.907591$ 


$$
\begin{array}{ccc}
\mathrm{H} & -3.6832580 .176042-1.621859 \\
\mathrm{H} & -2.489240-0.003620-2.932344 \\
\mathrm{H} & -2.884733-1.398891-1.904664 \\
\mathrm{C} & -1.2983541 .581021-1.167099 \\
\mathrm{H} & -0.9188511 .723909-2.188890 \\
\mathrm{H} & -2.1971802 .201004-1.036948 \\
\mathrm{H} & -0.5254561 .926256-0.467357 \\
\mathrm{C} & -2.708142-1.5374660 .698311 \\
\mathrm{H} & -2.668977-1.8529821 .749896 \\
\mathrm{H} & -3.756749 & -1.3635050 .419490 \\
\mathrm{H} & -2.311449-2.3567640 .081429 \\
\mathrm{C} & -2.4376210 .8516191 .382480 \\
\mathrm{H} & -3.4114291 .1753540 .985533 \\
\mathrm{H} & -2.5836600 .4985482 .412815 \\
\mathrm{H} & -1.7570341 .7114301 .407956 \\
\mathrm{H} & 3.985383-1.565636-1.192082 \\
\mathrm{H} & 4.267318-0.260752-0.000503 \\
\mathrm{H} & 4.3937870 .082296-1.746456 \\
\mathrm{C} & 2.1373041 .342379-0.754758 \\
\mathrm{C} & 1.9388041 .8080610 .548477 \\
\mathrm{H} & 1.9107651 .0936301 .372566 \\
\mathrm{C} & 1.7273163 .1668170 .781371 \\
\mathrm{H} & 1.5614343 .5216571 .799950 \\
\mathrm{C} & 1.7157054 .069234-0.282576 \\
\mathrm{H} & 1.5420675 .130693-0.098850 \\
\mathrm{C} & 1.9217763 .608426-1.583261 \\
\mathrm{H} & 1.9074584 .308328-2.420329 \\
\mathrm{C} & 2.1310232 .250243-1.816445 \\
\mathrm{H} & 2.2706811 .886662-2.837911 \\
\mathrm{H} & 1.935578-0.374243-2.003907
\end{array}
$$

\section{TSSR1Cat}
Al 0.9045440 .7559490 .185928
O $1.534695-0.9197150 .111552$
$\mathrm{N} \quad 2.3734831 .3618091 .341001$
C 2.2267582 .7302621 .857896
H 1.5716502 .6750192 .745063
O $\quad-0.7497070 .284335-0.301866$ 
$\mathrm{N} \quad 0.3431782 .6549110 .379580$

C 1.4556703 .5165010 .789048

H $2.1174293 .614980-0.094791$

C 1.1080194 .9140101 .284022

$\mathrm{H} \quad 0.4239344 .8261352 .146580$

H $\quad 0.5893265 .4888290 .503397$

C 2.3846875 .6519671 .693274

H 2.1283846 .6489942 .076860

H 3.0095795 .8110140 .798334

C 3.1769934 .8684872 .736047

H 2.5866904 .7946483 .664444

H 4.1050375 .3992862 .990076

C 3.5070353 .4531992 .257948

H 4.1974313 .4867031 .395671

H 4.0141172 .9146843 .070954

C 3.3667330 .6107501 .706135

H 4.1184541 .0354522 .384242

C $3.605738-0.7378211 .288536$

C $2.663057-1.4513880 .495698$

C $2.980057-2.7731400 .112305$

C $4.170188-3.3536470 .506778$

H $\quad 4.392746-4.3772260 .197647$

C $5.098517-2.6581921 .310106$

C $4.806901-1.3684321 .696299$

H $\quad 5.509165-0.8073092 .318121$

C $\quad-0.8084173 .1364740 .050454$

H $\quad-0.9736054 .2197740 .122775$

C $\quad-1.9351632 .364201-0.398789$

C $-1.8576670 .952383-0.536413$

C $\quad-3.0162350 .254544-0.930590$

C $-4.1958540 .935603-1.182640$

H $\quad-5.0800890 .373465-1.488303$

C $\quad-4.2752272 .334102-1.055247$

C $\quad-3.1510573 .032852-0.664888$

H $\quad-3.1893514 .119108-0.552002$

H $\quad-2.949668-0.829283-1.030471$

H $\quad-5.2103212 .854097-1.260440$ 

H $\quad 2.243409-3.319754-0.477882$
H $\quad 6.028725-3.1349521 .617069$
O $1.6382751 .142197-1.593545$
C $1.1771080 .310591-2.692557$
C $2.320152-0.671582-2.933834$
C $3.5792380 .073888-2.434854$
C $3.0391311 .384299-1.851489$
H $4.2946210 .278970-3.240761$
H $\quad 4.100747-0.513362-1.666923$
H $3.5092581 .691013-0.909886$
H $3.0948452 .213486-2.573006$
H $\quad 1.0088800 .981273-3.548721$
H $\quad 0.231745-0.149392-2.384691$
H $2.385779-0.950098-3.992642$
H $\quad 2.158727-1.583505-2.345230$
C $\quad-0.8864890 .3628583 .432525$
C $\quad-2.0281741 .1895172 .873232$
O $\quad-0.217473-0.3418482 .370034$
H $\quad-0.740389-1.0294451 .495963$
B $\quad-0.115566-1.9450962 .486202$
H $\quad-0.638532-2.0578281 .246318$
O $\quad-0.984636-2.5304853 .405674$
O $\quad 1.192376-2.3820312 .673203$
C $\quad-0.203142-3.3294784 .309266$
C $\quad 1.123258-3.5602493 .492190$
C $\quad-0.974217-4.6010354 .625896$
H $\quad-0.366370-5.2815765 .240224$
H $\quad-1.881828-4.3463675 .190065$
$\mathrm{H} \quad-1.278169-5.1217283 .710447$
C $\quad 0.014877-2.5258145 .588870$
$\mathrm{H} \quad-0.965496-2.2538896 .005508$
H $\quad 0.558312-3.1095226 .344698$
H $\quad 0.575876-1.6007655 .394817$
C $1.032788-4.7696522 .564311$
H $\quad 1.907951-4.7677521 .900497$
H $\quad 1.021713-5.7130483 .126991$
H $\quad 0.126558-4.7214711 .942963$ 

C $\quad 2.386826-3.6327894 .331881$
H $2.349224-4.4884765 .021593$
H $3.254416-3.7580333 .667642$
H $\quad 2.532038-2.7142314 .915455$
H $\quad-2.6662040 .5656522 .231228$
H $\quad-1.6552642 .0387092 .284433$
H $\quad-2.6559151 .5787053 .685446$
C $\quad 0.1636551 .1508004 .193959$
C 1.4520500 .6155564 .343783
H $1.685764-0.3485523 .882676$
C 2.4319561 .3156425 .045265
$\mathrm{H} \quad 3.4267930 .8801775 .165068$
C 2.1447222 .5633035 .604520
$\mathrm{H} \quad 2.9116073 .1087116 .157393$
C $\quad 0.8654143 .0991745 .464424$
H $\quad 0.6266564 .0677135 .907166$
C $\quad-0.1188302 .3966154 .764652$
H $\quad-1.1139332 .8330244 .669421$
H $\quad-1.302544-0.4054494 .103342$

\section{TSSR2}

C $\quad 2.8382511 .0203900 .924223$

$\mathrm{H} \quad 3.1383400 .5083101 .849744$

H 3.5559071 .8255550 .713228

$\mathrm{H} \quad 1.8473321 .4670981 .071247$

C $2.8012340 .034301-0.226672$

C $4.145769-0.616368-0.492439$

O $1.864646-1.0102830 .099742$

H $\quad 1.489386-1.733841-0.786698$

B $\quad 0.384895-0.841811-0.273929$

H $\quad 0.536495-1.896145-1.237356$

O $\quad 0.0199400 .339263-0.927048$

O $\quad-0.539750-1.1843090 .707644$

C $-1.2114410 .787220-0.342777$

C $-1.751308-0.5180750 .343824$

C $-2.1093211 .344430-1.435975$

H $\quad-3.1014731 .596229-1.031811$

H $\quad-1.6626472 .260456-1.848080$ 

H $\quad-2.2294470 .626033-2.255588$
C $\quad-0.8869251 .8764680 .676764$
H $\quad-0.2886972 .6556860 .183668$
$\mathrm{H} \quad-1.8003542 .3377681 .078477$
H $\quad-0.3071551 .4643031 .514796$
C $\quad-2.515090-1.409581-0.636415$
H $\quad-2.663439-2.393487-0.170798$
H $\quad-3.497414-0.985973-0.888148$
H $\quad-1.944385-1.552726-1.565360$
C $\quad-2.584581-0.2830161 .592617$
$\mathrm{H} \quad-3.4731530 .3225381 .358869$
$\mathrm{H} \quad-2.920710-1.2499921 .991782$
H $\quad-2.0011990 .2215422 .372014$
H $4.084341-1.318714-1.335639$
H $4.480968-1.1681200 .397453$
H $4.8963180 .148020-0.735922$
H $2.4388400 .546150-1.132752$

\section{TSSR3}

O $\quad 0.4227670 .2086372 .615045$

C $\quad-0.153498-0.9268232 .711450$

C $0.676433-2.1712062 .570522$

H $\quad 0.256653-3.0212903 .119495$

H $\quad 1.695039-1.9546352 .911490$

H $\quad 0.703663-2.4157371 .496186$

C $-1.630453-0.9852112 .544416$

C $\quad-2.300374-2.1826592 .264146$

H $\quad-1.751657-3.1223682 .189689$

C $\quad-3.678047-2.1749822 .061739$

H $\quad-4.199361-3.1054501 .833732$

C $\quad-4.387169-0.9763792 .151813$

$\mathrm{H} \quad-5.467218-0.9733661 .995460$

C $\quad-3.7222530 .2172282 .441136$

$\mathrm{H} \quad-4.2816551 .1504032 .516314$

C $\quad-2.3451210 .2179922 .632811$

H $\quad-1.7998701 .1305942 .878129$

B $\quad 0.5353910 .2179964 .248121$

O 1.8977500 .2896094 .608581 

O $\quad-0.1859251 .3107964 .777086$
C 2.0351631 .4186815 .471847
C $\quad 0.7989062 .3010975 .077375$
C 0.2768333 .1919376 .192355
C 1.0625903 .1278533 .816848
C 3.3811262 .0799915 .219780
C 1.9481870 .9229406 .915470
H $\quad 0.9572580 .4891717 .113162$
H 2.1336641 .7292277 .639763
H 2.7039280 .1385907 .059984
H 3.5192622 .2944534 .153105
H 4.1884711 .4065385 .540380
H 3.4679533 .0179555 .788827
$\mathrm{H} \quad 1.4783622 .5004763 .016275$
H 1.7530353 .9603404 .014599
H $\quad 0.1070893 .5437053 .465998$
H $\quad-0.0684792 .5934327 .044145$
H $\quad-0.5734353 .7828405 .823284$
H $\quad 1.0581843 .8874346 .534424$
H $\quad-0.051086-0.8890394 .49423$

\section{TSSR3Cat}
Al 1.5539370 .1816120 .522496
O $1.471134-1.5680240 .115694$
N $3.353000-0.0659861 .361002$
C 3.9006491 .1721331 .933179
H 3.4096911 .2958232 .915940
O $\quad-0.0572920 .588854-0.215364$
$\mathrm{N} \quad 1.9758252 .0915410 .827050$
C 3.4107072 .3087611 .018306
H 3.8742172 .1348940 .026938
C 3.8599493 .6799511 .505405
H 3.3958603 .9040522 .480206
H 3.5345374 .4609750 .801628
N $\quad-2.994135-0.076198-2.133010$
C 5.3837783 .7030531 .637337
H 5.7121364 .6873391 .998572
H 5.8351643 .5674920 .639922 

C $\quad 5.8745372 .5998832 .571089$
H 5.4925872 .7855403 .587835
H 6.9707662 .6176542 .642140
C 5.4151281 .2156242 .107865
H 5.8960110 .9629621 .145400
H 5.7383150 .4635662 .841976
C $3.971183-1.1924591 .455947$
H $4.938655-1.2257631 .974908$
C $3.529010-2.4559820 .907706$
C $2.301892-2.5763660 .196253$
C $1.975116-3.811977-0.435001$
C $2.844662-4.883365-0.244736$
H $\quad 2.610730-5.844035-0.702194$
C $4.027921-4.7873800 .507251$
C $4.374554-3.5740741 .061552$
H $\quad 5.306160-3.4633931 .621777$
C 1.1073933 .0416450 .807511
H 1.4284604 .0698081 .027588
C $\quad-0.2920672 .8701610 .498940$
C $\quad-0.8098451 .641458-0.012398$
C $\quad-2.1990991 .572954-0.296378$
C $\quad-3.0181902 .673757-0.049084$
$\mathrm{H} \quad-4.0986572 .561742-0.203560$
C $\quad-2.5000333 .8887890 .421077$
C $\quad-1.1464573 .9782080 .683014$
H $\quad-0.7184924 .9123351 .056930$
C $\quad-2.8250190 .259013-0.656301$
H $\quad-2.233526-0.568439-0.239111$
$\mathrm{H} \quad-3.8493430 .235423-0.251384$
C $-3.7866810 .991088-2.872046$
$\mathrm{H} \quad-4.5975951 .274064-2.180645$
H $\quad-4.2634570 .475538-3.716343$
C $\quad-1.647090-0.315117-2.740095$
H $\quad-1.136657-1.029375-2.079399$
$\mathrm{H} \quad-1.1111480 .637475-2.646157$
C $-1.668869-0.811338-4.173876$
H $\quad-2.055099-1.836059-4.254704$ 


$$
\begin{aligned}
& \text { H } \quad-0.635759-0.824679-4.549486 \\
& \text { H } \quad-2.254700-0.164229-4.840568 \\
& \text { C }-3.819006-1.324751-2.147917 \\
& \text { H } \quad-3.980185-1.642643-3.182696 \\
& \text { H } \quad-4.781187-1.092002-1.665427 \\
& \text { H } \quad-3.283083-2.098577-1.584422 \\
& \text { C } \quad-3.0047012 .189157-3.380430 \\
& \text { H } \quad-2.4630352 .720432-2.590544 \\
& \text { H } \quad-3.7361302 .889838-3.805758 \\
& \text { H } \quad-2.3005151 .927823-4.181851 \\
& \text { H } \quad-3.1611344 .7375640 .591508 \\
& \text { C } \quad 0.742569-3.906237-1.345552 \\
& \text { H } 4.668783-5.6601120 .628396 \\
& \text { I }-6.4675160 .768541-0.114426 \\
& \text { C } 0.923834-2.920092-2.515573 \\
& \text { C } \quad-0.554204-3.578940-0.582190 \\
& \text { C } 0.587833-5.311936-1.936720 \\
& \text { H } \quad 1.459828-5.602879-2.539934 \\
& \text { H } \quad-0.293198-5.336323-2.593709 \\
& \text { H } \quad 0.438630-6.068703-1.152470 \\
& \text { H } \quad 1.822712-3.178314-3.097027 \\
& \text { H } \quad 1.017106-1.885082-2.152647 \\
& \text { H } \quad 0.057754-2.981412-3.193623 \\
& \text { H } \quad-0.555427-2.550679-0.194313 \\
& \text { H } \quad-0.695495-4.2798880 .255728 \\
& \text { H } \quad-1.416527-3.706039-1.256819 \\
& \text { O } 0.665103-0.0272552 .323719 \\
& \text { C } \quad-0.033682-1.0920402 .657515 \\
& \text { C } \quad 0.668314-2.4062272 .825616 \\
& \text { H } \quad 0.237976-2.9681273 .662827 \\
& \text { H } \quad 1.737589-2.2402132 .994705 \\
& \text { H } \quad 0.533097-2.9952851 .907487 \\
& \text { C }-1.488826-1.0614172 .529650 \\
& \text { C } \quad-2.214033-2.2635822 .402969 \\
& \text { H } \quad-1.698393-3.2238872 .391161 \\
& \text { C } \quad-3.595892-2.2310902 .267568 \\
& \text { H } \quad-4.153851-3.1607182 .150734
\end{aligned}
$$



C $\quad-4.271949-1.0067052 .291302$
H $\quad-5.355710-0.9634982 .167527$
C $\quad-3.5601780 .1880162 .439656$
H $\quad-4.1078791 .1323772 .432972$
C $\quad-2.1760650 .1690562 .547202$
H $\quad-1.6132911 .0944952 .675406$
B 0.6762060 .3254454 .146274
O 2.0052670 .5277384 .516864
O $\quad-0.1316431 .3954254 .481061$
C 1.9418711 .5235715 .561514
C 0.6959542 .3765315 .127243
C $\quad-0.0805732 .9941446 .276890$
C 1.0550393 .4313774 .090080
C 3.2515512 .2898725 .604160
C $\quad 1.7155670 .7957596 .884290$
H $\quad 0.7572280 .2563916 .879209$
H 1.7175021 .4917077 .733842
H 2.5223480 .0645127 .027982
H 3.4788482 .7616524 .639842
H 4.0719311 .6037635 .858814
H $\quad 3.2120513 .0757176 .372340$
H 1.6671812 .9703323 .304825
H $\quad 1.6074394 .2737734 .531029$
H $\quad 0.1279663 .8110563 .636718$
H $\quad-0.4859872 .2224866 .941517$
H $\quad-0.9229213 .5772735 .880444$
H $\quad 0.5620083 .6691976 .861081$
H $\quad 0.142234-0.7808014 .355651$
O $2.4485060 .497680-1.281812$
C $1.8823591 .374179-2.277081$
C $2.9571401 .471440-3.345345$
C $3.5416360 .059659-3.317392$
C $3.553799-0.255174-1.828375$
H $4.539380-0.015232-3.766376$
H $\quad 2.874359-0.639054-3.843857$
H $\quad 3.402545-1.318206-1.604160$
H $4.4771250 .090873-1.335916$ 
H $\quad 1.6249932 .325673-1.794150$

H $\quad 0.9611650 .909054-2.657142$

H $3.7190892 .212403-3.059212$

H $2.5502631 .759361-4.322490$

\section{TSSR4/SR5}

C $1.315196-0.9857210 .360707$

C $1.6256550 .315974-0.462066$

C $2.176344-1.1020271 .612993$

C $\quad 1.360087-2.272468-0.445587$

O $\quad-0.029866-0.7583430 .829292$

C $3.0990770 .702768-0.447713$

O $\quad 0.8910421 .3150620 .226013$

C $1.1419780 .229194-1.913925$

B $\quad-0.2764770 .7917600 .805695$

H $2.364112-2.418074-0.869895$

H $\quad 0.634795-2.258812-1.269779$

H $\quad 1.132360-3.1297300 .203164$

H $\quad 1.767023-1.8957242 .252226$

H $2.161470-0.1585182 .176041$

H $3.216297-1.3507991 .360973$

H 3.4342210 .9367700 .569757

H $3.2417741 .599524-1.066075$

H $3.724159-0.104430-0.858608$

H $1.770972-0.448102-2.509411$

H $\quad 1.1987781 .236166-2.349204$

H $\quad 0.096745-0.100005-1.980492$

H $\quad-0.6808401 .3051241 .823241$

C $\quad-2.8039450 .8313060 .153028$

C $\quad-3.6471800 .757389-1.107154$

C $-3.306493-0.0987131 .247212$

O $\quad-1.4542050 .522495-0.198784$

$\mathrm{H} \quad-2.7975401 .8667860 .530258$

H $\quad-0.946359-0.5615770 .051910$

$\mathrm{H} \quad-3.2409731 .424360-1.879005$

H $\quad-4.6854011 .049069-0.895976$

H $\quad-3.648982-0.270101-1.501536$

H $\quad-2.671047-0.0344022 .140944$ 


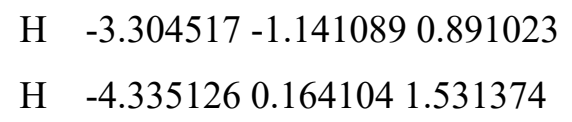

\section{TSSR6}

C 3.1320511 .0508420 .495923

H 2.1558320 .5123441 .090230

H 3.9873180 .9328981 .168081

H 2.7134622 .0574500 .407082

C $3.1000690 .260598-0.662579$

C $4.125594-0.763016-0.984698$

O $1.528300-1.166796-0.398656$

H $1.741044-1.9863020 .065104$

B $\quad 0.549311-0.4200730 .396783$

H $1.235374-0.0444671 .494934$

O $\quad 0.1203430 .729489-0.339344$

O $\quad-0.590167-1.1298320 .875574$

C $\quad-1.2658070 .891391-0.069778$

C $-1.720277-0.5839830 .202993$

C $-1.9338231 .548123-1.268246$

H $\quad-3.0270061 .578533-1.143332$

$\mathrm{H} \quad-1.5702442 .580635-1.370971$

H $\quad-1.6936681 .009619-2.193429$

C -1.4248351 .7730611 .171144$

$\mathrm{H} \quad-0.8840752 .7153971 .001521$

H $\quad-2.4794072 .0063231 .377338$

H $\quad-0.9939321 .2771602 .052951$

C $\quad-1.928822-1.361388-1.098540$

H $\quad-2.025579-2.428444-0.853877$

H $\quad-2.835073-1.039573-1.631898$

H $\quad-1.058854-1.235375-1.759035$

C $\quad-2.943982-0.7136171 .096878$

H $\quad-3.812259-0.2030520 .652400$

H $\quad-3.195768-1.7761901 .222646$

H $\quad-2.749637-0.2917012 .090669$

H $3.719224-1.535105-1.647462$

H $4.540549-1.216657-0.074015$

H $4.952423-0.254645-1.509068$

H $2.4388590 .580320-1.470799$ 


\section{TSSR7CI}

C $\quad 1.5225861 .0036274 .339925$

H 1.8531032 .0545544 .340038

$\mathrm{H} \quad 0.7082620 .8874445 .072411$

H 2.3709990 .3740124 .641483

C 1.0717840 .6226782 .932078

C $\quad-0.1450721 .4484792 .505467$

O 2.1515410 .7932462 .073528

H $1.950991-1.1184500 .970001$

B 2.1295170 .1106550 .765245

H $2.931451-1.2281262 .481327$

O $1.0956900 .680174-0.140588$

O 3.3969220 .3410960 .061221

C $1.7084011 .072164-1.335448$

C $3.1851681 .348016-0.888220$

C $\quad 0.9838202 .286788-1.908919$

H $1.5121562 .695292-2.786277$

$\mathrm{H} \quad-0.0311241 .994807-2.220374$

H $\quad 0.8913063 .071832-1.147156$

C $1.638721-0.089194-2.337589$

H $2.0164710 .186070-3.335642$

H $2.219502-0.938934-1.951235$

H $\quad 0.587998-0.402072-2.427397$

C $3.3180892 .722783-0.215989$

$\mathrm{H} \quad 4.2962492 .7612060 .285711$

H $3.2506043 .554462-0.936350$

$\mathrm{H} \quad 2.5427032 .8282870 .555385$

C $4.2207341 .217229-2.001590$

H $4.0152081 .916507-2.828671$

H $5.2192021 .441257-1.595961$

H $\quad 4.2391730 .191444-2.392725$

$\mathrm{H} \quad-0.4498301 .1729281 .488608$

$\mathrm{H} \quad 0.1270412 .5170582 .498858$

H $\quad-0.9858981 .3036233 .203982$

H $\quad 0.764490-0.4489252 .945346$

Cl $3.393611-2.0101773 .427757$

\section{TS SR7I}



C $\quad 0.4416020 .8288833 .449046$
$\mathrm{H} \quad 0.3841811 .9284573 .474606$
H $\quad-0.4625650 .4152293 .922845$
H 1.3225330 .5199934 .029657
C $\quad 0.5770340 .3691242 .000367$
C $\quad-0.6580470 .7620111 .185545$
O 1.7453900 .9123411 .478982
H $2.410507-0.9307570 .454681$
B 2.3080110 .3087480 .254242
H $3.124165-0.6375192 .146928$
O $1.4946500 .625340-0.947239$
O $3.6256170 .891081-0.028631$
C $2.3335261 .176069-1.922624$
C $3.4738961 .822269-1.063630$
C $1.5449852 .165136-2.776230$
H $2.1993482 .697228-3.486238$
H $\quad 0.7780561 .622606-3.350152$
H $1.0340852 .898481-2.138868$
C $2.8777910 .046371-2.808856$
H $3.4673460 .419480-3.661722$
H $3.502195-0.624517-2.201475$
H $2.022798-0.530605-3.190972$
C $3.0316903 .169812-0.475457$
H 3.7559903 .4562980 .301150
H $2.9834923 .967690-1.234370$
H 2.0517373 .0505160 .007746
C $4.8023981 .987452-1.794911$
H $4.6927682 .617357-2.693117$
H $\quad 5.5310142 .464377-1.122181$
H $\quad 5.2053111 .008988-2.087508$
H $\quad-0.5397810 .4402300 .143725$
$\mathrm{H} \quad-0.7612801 .8595621 .188360$
H $\quad-1.5725540 .3203251 .615049$
H $\quad 0.643832-0.7438771 .991732$
I $3.884501-1.3788123 .407806$

\section{TS}

C $\quad 0.8723591 .3198852 .706858$ 

C $\quad 0.3496972 .6648432 .179658$
O 1.9645180 .8761841 .982125
H $\quad 0.971328-0.8200250 .956330$
B 1.7031890 .1671590 .701170
H $1.632767-1.2174562 .613475$
O $1.0933191 .075032-0.301547$
O $2.969441-0.2531160 .098908$
C $1.8731321 .052530-1.464147$
C $3.2886720 .657125-0.918041$
C $1.8152352 .417456-2.144583$
H $2.5069332 .472566-3.001331$
H $\quad 0.7937822 .600234-2.512329$
H $2.0650933 .212182-1.429804$
C $1.321731-0.020404-2.41366$
H $1.827227-0.021259-3.392621$
H $1.428677-1.011216-1.949259$
H $\quad 0.2500230 .175054-2.565938$
C $4.0116311 .868687-0.312340$
$\mathrm{H} \quad 4.8760431 .4999250 .259283$
H $4.3650642 .576408-1.079707$
H 3.3400252 .3821910 .389526
C $4.191970-0.024099-1.940934$
H $4.3616910 .619931-2.819414$
H $5.165836-0.245032-1.478389$
H $3.752387-0.974252-2.271397$
H $\quad 0.0849342 .5521841 .121546$
H 1.1521653 .4139652 .264813
H $\quad-0.5211763 .0159082 .754972$
H $\quad 0.0417130 .5803052 .642287$
Cl $1.528276-1.9898933 .662765$
C 1.2366351 .4465624 .180122
C 0.2567311 .7224615 .141012
H $\quad-0.7870431 .8159984 .827948$
C $\quad 0.5911071 .8650086 .486362$
H $\quad-0.1888952 .0734917 .222272$
C $\quad 1.9199371 .7342476 .893375$
H 2.1865941 .8422877 .947057 
C 2.9013601 .4542545 .942914

H 3.9424091 .3408396 .254349

C 2.5629251 .3091024 .597135

H 3.3082251 .0699783 .838124 


\section{Bibliography}

[1] Brodbeck, D.; Broghammer, F.; Meisner, J.; Klepp, J.; Garnier, D.; Frey, W.; Kästner, J.; Peters, R. An Aluminum Fluoride Complex with an Appended Ammonium Salt as an Exceptionally Active Cooperative Catalyst for the Asymmetric Carboxycyanation of Aldehydes. Angew. Chem. Int. Ed. 2017, 56, 4056-4060.

[2] Titze, M.; Heitkämper, J.; Junge, T.; Kästner, J.; Peters, R. Highly Active Cooperative Lewis Acid-Ammonium Salt Catalyst for the Enantioselective Hydroboration of Ketones. Angew. Chem. Int. Ed. 2021, 60, 5544-5553.

[3] Broghammer, F.; Brodbeck, D.; Junge, T.; Peters, R. Cooperative Lewis Acid-Onium Salt Catalysis as Tool for the Desymmetrization of Meso-Epoxides. Chem. Commun. 2017, 53, 1156-1159.

[4] Wu, D.; Wang, R.; Li, Y.; Ganguly, R.; Hirao, H.; Kinjo, R. Electrostatic Catalyst Generated from Diazadiborinine for Carbonyl Reduction. Chem 2017, 3, 134-151.

[5] Linshoeft, J.; Heinrich, A.; Segler, S.; Gates, P.; Staubitz, A. Chemoselective Cross-Coupling Reactions with Differentiation Between two Nucleophilic Sites on a Single Aromatic Substrate. Org. Lett. 2012, 14, 5644-5647. 